\title{
إنتاج الطاقة الكهربائية فى محافظة حلوان
}

*رضا سليمان السيا حسانين

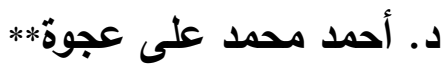

***. أ.د. محمد صدقى على الغماز

تعـــ الطاقـة الكهربائيـة إنتاجـا واسـتهلاكا؛ بمثابـة الركيـزة الأساسـية للتتميـة

الاقتصـادية والاجتماعية فى محافظة حلوان، وأصبح استخدامها مؤشرا من مؤثرات

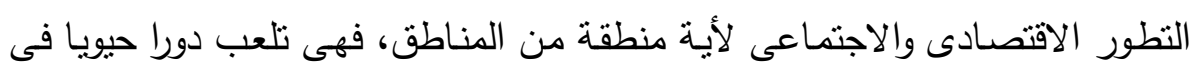
قطاعات النشاط الاقتصادى المختلفة. ومحافظة حلوان من المناطق التى نتهر

$$
\text { * - معيد بقسم الجغرافيا، كلية الآداب (جامعة عين شمس). }
$$

*** أستاذ الجغرافيا الاقتصادية المساعد بقسم الجغرافيا، كلية الآداب (جامعة عين شثمس). ***** أستاذ الجغرافيا الاقتصادية بقسم الجغرافيا، كلية الآداب (جامعة عين شمس). 
نمـوا مطردا فـى بنائها الصـناعى، وكذا العمرانـى بعد القرار الجمهورى بإنشـائها وضـم

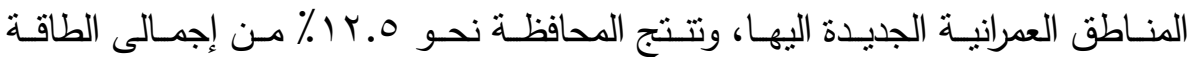
الكهربائية على مستوى الجمهورية. ومن هنا نجد أن للطاقة الكهربائية فى محافظة حلوان أهمية كبيرة، فهى ركيزة أساسية لدفع عجلة التقدم والحضارة حيث تشكل الدعامة الرئيسية لجميع خطط التتمية والأساس الحيوى للتطور الاقتصادى والاجتماعى فى محافظة حلوان، من هنا كان اختيار هذه المنطقة للدراسة حيث تتهذ محافظة حلوان نموا مطردا فى بنائها الصـناعى وهـى قطب صـناعى قديم فـى مصـر ، الأمـر الذى أدى إلى الاعتمـاد على الكهربـاء فى الاثتاج الصناعى، ويستلزم الأمر دراسـة هذا القطاع دراسـة جغرافيـة لمعرفة دورها فى هذا الخصوص.

وتتركز بمنطقة الدراسـة المحطات الحراريـة لإنتاج الطاقة الكهربائية حيث تسهم هذه المحطات بنحو ؟ ؟ من إجمالى الطاقة الكهربائية المولدة بإقليم القاهرة الكبرى،

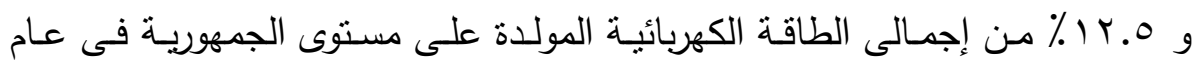

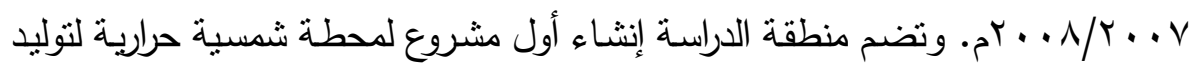
الطاقة الكهربائية فى مصر بمنطقة الكريمات بمركز أطفيح بقدرة كهربائية تقدر بنحو

$$
\text { • ع ام.و • ومن أجل هذا كانت هناك ضرورة : }
$$

1- للتعرف على التوزيع الجغرافى لمحطات نوليد الطاقة الكهربائية بمنطقة الدراسة. r- ولدراسة القدرة الاسمية المركبة والحمل الاقصى بمحطات توليد الطاقة الكهربائية بمنطقة الدراسة.

r- وكذلك للتعرف على الطاقة الكهربائية المنتجة بمنطقة الدراسة. ع - ولدراسة موسمية إنتاج الكهرباء بالمحافظة. 0- وللتعـرف على معـدلات اسـتهلاك الوقـود والكفـاءة الحراريـة وتكـاليف الانتـاج بمحطات التوليد الكهربائى فى منطقة الدراسة. 
سنحاول الاعتماد على مناهج البحث فى الجغرافيا الاقتصادية، واهمها: المنهج الاقليمى والمنهج الموضوعى الذى يتيح التغطية العلمية الكاملة لمفردات البحث، كما يتيح دراسـة العناصر الرئيسية الثلاثة للجغرافيـة الاقتصـادية ومنها الإنتاج. وسيركز الطالب على مناهج جغرافية الطاقة (منهج النظام)، والذى تتضح من خلاله العناصر المختلفة للطاقـة الكهربائية ومنها إنتاج الطاقـة.وتركز جغرافيـة الطاقـة الاهتمـام على توضيح الخصـائص المكانيـة لإنتاج الطاقـة، واحيانـا يطلاق عليها صـناعة الطاقة، وتتضمن الأسئلة التالية('): 1- أين تقع هذه الصناعة ؟ r- ب - لماذا تقع هناك ؟ r- كيف يختلف انتاجها (كما وكيفا) من مكان لآخر ؟ ع - هل نمط انتاجها يتشم بالموسمية ؟

$$
\text { أما عن أساليب البحث، فهناك: }
$$

أ- الدراســة الميدانيـة وذلك بهدف التأكد من صحة البيانـات المجمعة، واستكمال

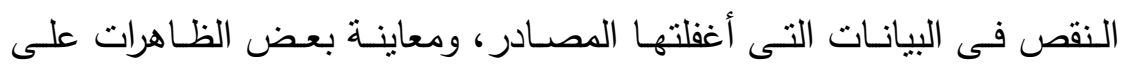

$$
\text { الطبيعة، وقد اعتمدت الدراسة الميدانية على: }
$$

1- الملاحظـة المباشـرة وتسـجيل الظـاهرات وتعليلها: حيث قام الطالب بزيـارة محطـات توليد الطاقـة الكهربائيـة بمنطقـة الدراسـة؛ بغرض التعـرف على مكونـات هذه المحطـات ومعاينـة طـرق تشـغيل هذه المحطـات المختلفـة ومعرفة المشكلات المختلفة بهذه المحطات.

(1) سعيد أحمـد عبـده، جغرافية الطاقـة: مفهومها، وبحاهـا، ومناهجها، المجلة الجغرافيـة العربية، السـنة الواحدة والثلاثون، العدد الرابع والثلاثون، القاهرة، 999 (م) ص 11 ا. 
r- المقابلات الثخصية مع المسؤلين وأصحاب الخبرة، بغرض الاستفسار عن بعض الملاحظات، وخاصة مع مسئولى: محطات التوليد بمنطقة الدراسة،

$$
\text { وشركة القاهرة لإنتاج الكهرباء. }
$$

r- التقاط الصور الفوتوغرافيـة، والتى سـاعدت فى توضيح مكونـات محطـات التوليد بمنطقة الدراسة.

ب- الأسلوب الكمى، حيث تم الاستعانة ببعض الاسـاليب الكمية فى مجال الطاقة مثل: معامل الجودة، ومعامل الحمل، ومعامل السعة. ج- الأسـلوب الكـارتوجرافى: حيث تم الاستعانة بالحاسـب الآلى فى رسم الخرائط والأشـكال البيانيـة؛ لبلورة نتائج التحليـل، وإظهار الحقائق المختلفة فى صـورة مرئية.

الاسراسات السابقة :

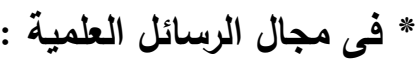
1- دراسـة جيهان محمد الصـاوى، إنتاج الطاقة الكهربائية واستهلاكها فى محافظة البحيرة - دراسة فى الجغرافيا الاقتصادية(')، تتاولت فيها نطور الطاقة الكهربائية بمحافظــة البحيـرة، وإنتاج ونقل وتوزيـع واسـتهلاك الطاقـة الكهربائبـة، وكهربـة الريف، ومستقبل الطاقة الكهربائية بالمحافظة.

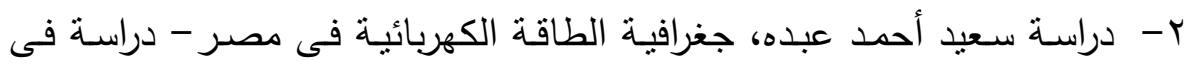
الجغرافيا الاقتصادية(؟)، تتاولت مراحل تطور الطاقة الكهربائية فى مصر وإنتاج (1) جيهان ابوبكر محمد الصاوى، إنتاج الطاقة الكهربائية واستهلاكها في محافظة البحيرة دراسة فن

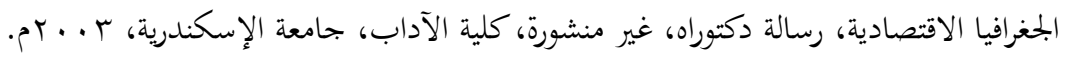

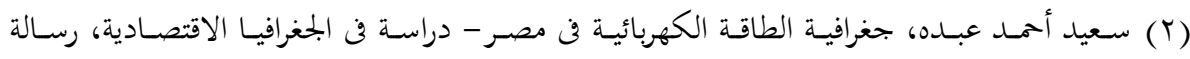
ماجستير، غير منشورة، كلية البنات، جامعة عين شمس، لو 99 ام. 
ونقلـ وتوزيــع الطاقـة الكهربائيـة، وتوطن محطـات الكهربـاء، وانوعاهـا

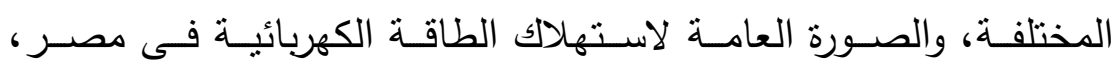
ومشروع كهربة الريف، ومستقبل الطاقة الكهربائية فى مصر .

r- دراسـة محمد محمد عبدالقادر رمضـان، استهلاك الطاقـة فى مصر -

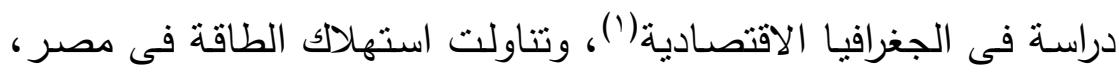
من خلال استهلاك البترول، والغازالطبيعى، والكهرباء، ومستقبل الطاقة

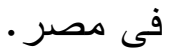

ع- دراسة محمد محمود محمد خميس، الطاقة الكهربائية فى منطقة القاهرة

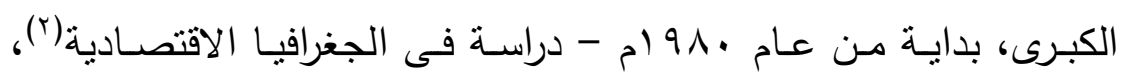
وتتاولت إنتاج الطاقة الكهربائية فى منطقة القاهرة الكبرى، واساليب نوليد الطاقـة الكهربائيـة، والخصـائص الاقتصـادية لاتنـاج الطاقـة الكهربائيـة

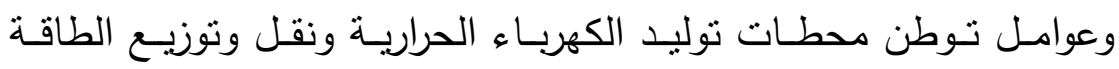
الكهربائية، واقتصاديات نقل وتوزيع الطاقة الكهربائية، والثبكة الموحدة مع النطبيق على القاهرة الكبرى واستهلاك الطاقة الكهربائية فى منطقة

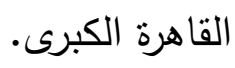

(1) (مماد محمد عبدالقادر رمضان، استهلاك الطاقة في مصر - دراسة فن الجغرافيا الاقتصادية، رسالة دكتوراه، غير منشورة، كلية الآداب، جامعة الإسكندرية، 991 ام.

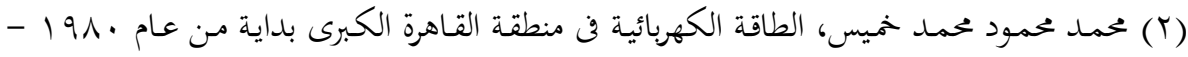

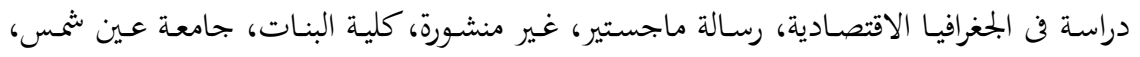
. 


\section{" وفى مجال الاوريات هناك بحوث عديدة نذكر منها:}

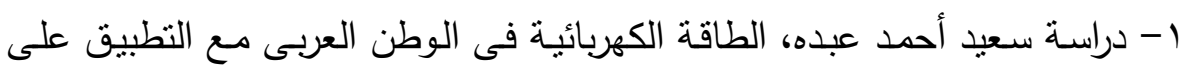

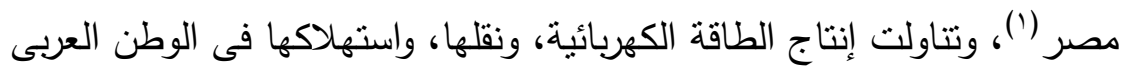

مع التطبيق على جمهورية مصر العربية.

r- دراسـة سعيد أحمد عبده، إنتاج واستهلاك الطاقة الكهربائيسة فى سلطنة عمـان

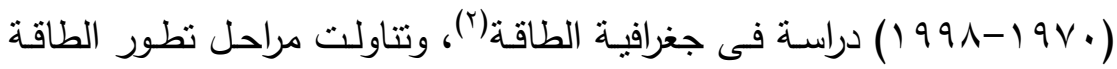
الكهربائية فى سلطنة عمان، وتطور إنتاج الكهرباء والعوامل المؤثرة فى توزيع محطات الكهرباء، ونقل وتوزيع واستهلاك الكهرباء، ونظرة مستقبلية عن الطاقة فى سلطنة عمان.

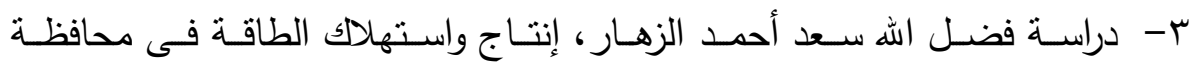

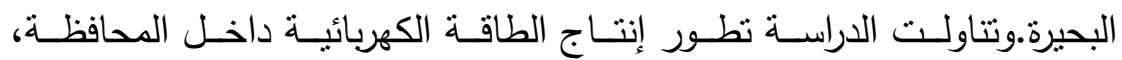
واستهلاك الطاقة، ومنوسط نصيب الفرد من استههلاك الكهرباء، وكهربة الريف، واقتصاديات إنتاج الطاقة الكهربائية(r).

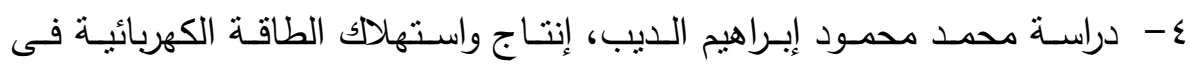
مصر (؛)، وتتاولت الدراسة تطور إنتاج الكهرباء ونقلها وتوزيعها بجمهورية مصر إنهر

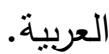

سعيد أحمد عبده، الطاقة الكهربائية فن الوطن العرى مع التطبيق على مصر، الجزء الأول، مركز بحوث

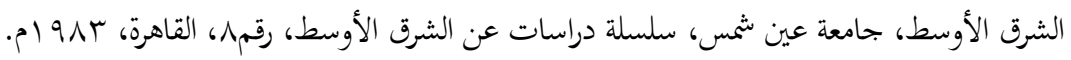

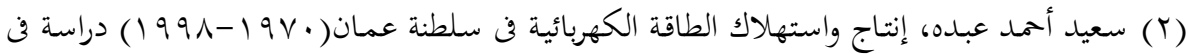
جغرافية الطاقة، المجلة الجغرافية العربية، العدد الثامن والثلاثون، السنة الثالثة والثلاثون، القاهرة، الجزءء

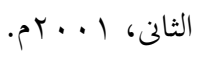

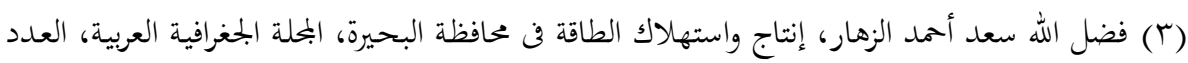

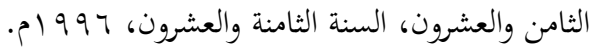

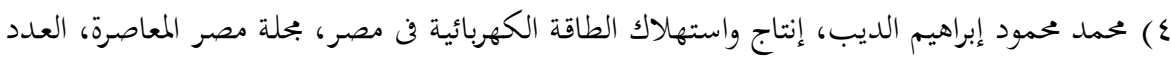

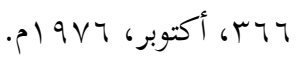


0- دراسـة محمـد أحمد محمـود مرعـى، إنتاج الكهربـاء، واستهلاكها فى محافظـة دميـاط-دراسـة فى الجغرافيـا الاقتصـادية(')، وتتاولت البـدايات الأولى لدخول الكهرباء فى محافظة دمياط، ودراسة الإنتاج ونقل الكهرباء وتوزبعها واستهلاكها فى محافظة دمياط.

צ- دراسـة محمد فراج حسـانين، إنتاج الطاقـة الكهربائيـة واستهلاكها فى محافظـة الدقهلية-دراسـة فى جغرافية الطاقة(؟)، وتتاولت مراحل دخول الكهرباء وانتاجها فى محافظـة الدقهليـة، ودراسـة شبكة نقل وتوزيـع الكهربـاء، وأوجـه الاستهلاكك المختلفـة للكهربـاء، ومتوسط نصـيب الفـرد منهـا، ودراسـة توطن محطـة إنتاج الكهرباء، والعوامل المؤثرة فى توطنها بالمحافظة. - دراسة وفيق محمد جمال الدين إبراهيم، إنتاج الطاقة الكهربائية واستهلاكها فى - V

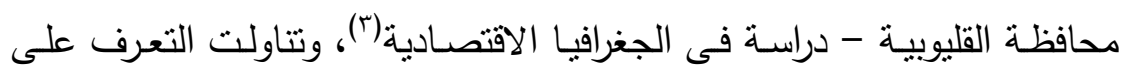
مصـادر إنتـاج الطاقـة الكهربائيـة، وشـبكة نقل الكهربـاء وتوزيعهـا بالقليوبيـة،

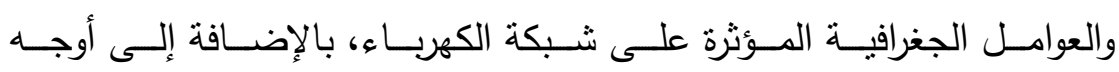
الاستخدامات المختلفة للكهرباء، ومتوسط نصيب الفرد منها، واقتصاديات إنتاج الكهرباء، والمشاكل التى تعترى قطاع الكهرباء فى المحافظة، ووسائل النهوض به. (1) محمــ أحمـد محمـود مرعى، إنتـاج الكهربـاء واستهلاكها في محافظة دميـاط- دراسـة في الجغرافيـا

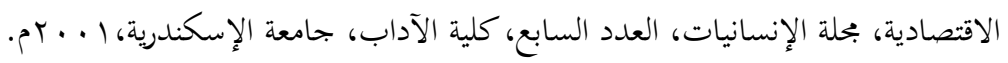

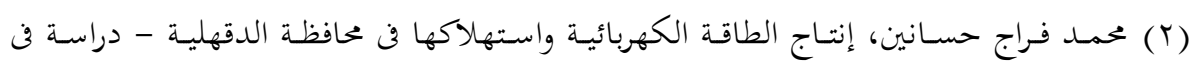

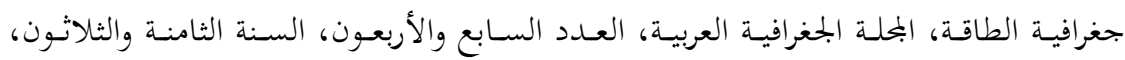

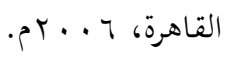
(r) وفيق محمد جمال الدين إبراهيم، إنتاج الطاقة الكهربائية واستهلاكها فن محافظة القليوبية - دراسة في

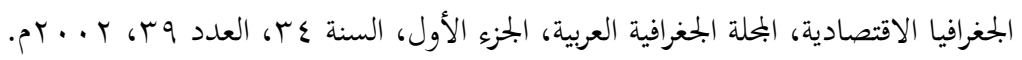


تتميز محافظة حلوان بأنها من أكبر المحافظات المصرية إنتاجا للطاقة الكهربائية، نظرا لامتدادها الكبير فى شكل طولى، هذا فضـلا عن التتوع فى مركبها الاقتصـادى

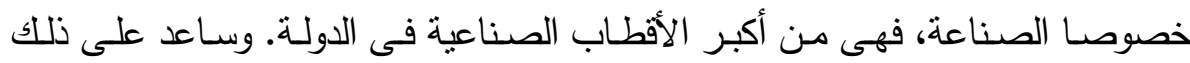
وقوعها بين إقليمى القاهرة الكبرى ومصر الوسطى جنوبا، فقد وقعت ضمن نطاق ثالاث شركات لإنتاج الطاقة الكهربائية من أصل ست شركات رئيسية منتجة للطاقة الكهربائية فى الدولة هى: شركة القاهرة لإنتاج الكهرباء وشرق الدلتا، والوجه القبلى. ويشمل النطاق الجغرافى التى تغطيه شركة القاهرة لإنتاج الكهرباء إقليم القاهرة الكبرى حيث تقع كل من: حلون، والمعادى، و 0 (مايو ، والتبين، والقاهرة الجديدة، ضمن هذا النطاق الجغرافى وهى من الأقسام الإدارية لمحافظة حلوان منطقة الدراسة.

وينتبين من شكل (1) أن النطاق الجغرافى الذى تغطيه شـركة الوجه القبلى لإنتاج الكهرباء يشمل محافظة 7 أكتوبر (ما عدا ما يدخل فى نطاق القاهرة الكبرى)، وجنوب محافظة حلوان، والفيوم، وبنى سويف، والمنيا، وأسيوط، والوادى الجديد، وسوهاج، وأسوان. ويدخل ضمن هذا النطاق الجغرافى كل من مركزى: الصف، وأطفيح وهما من المراكز الإدارية لمحافظة حلوان منطقة الدراسة. بينما يدخل كل من قسمى : الثـروق، وبدر ضمن النطاق الجغرافى الذى تغطيه شركة شرق الدلتا لإنتاج الكهربـاء؛ وهما الامتداد الثمالى الثرقى لمحافظة حلوان (منطقة الدراسة).

ويحـاول هـذا البحـث أن يتتـاول التوزيـع الجغرافـى لمحطــات نوليـد الطاقـة

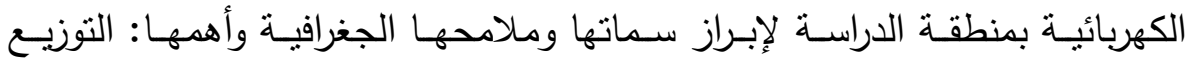
الجغرافـى لمحطـات توليـد الطاقـة الكهربائيـة، والقـدرة الاســية المركبـة، والحمـل الأقصى، والطاقة الكهربائية المنتجة، وموسمية إنتاج الكهرباء، ومعدلات استهلاك الوقود ... إلخ من المتغيرات المستخدمة فى قياس البناء الكهربائى لمنطقة الدراسة. 


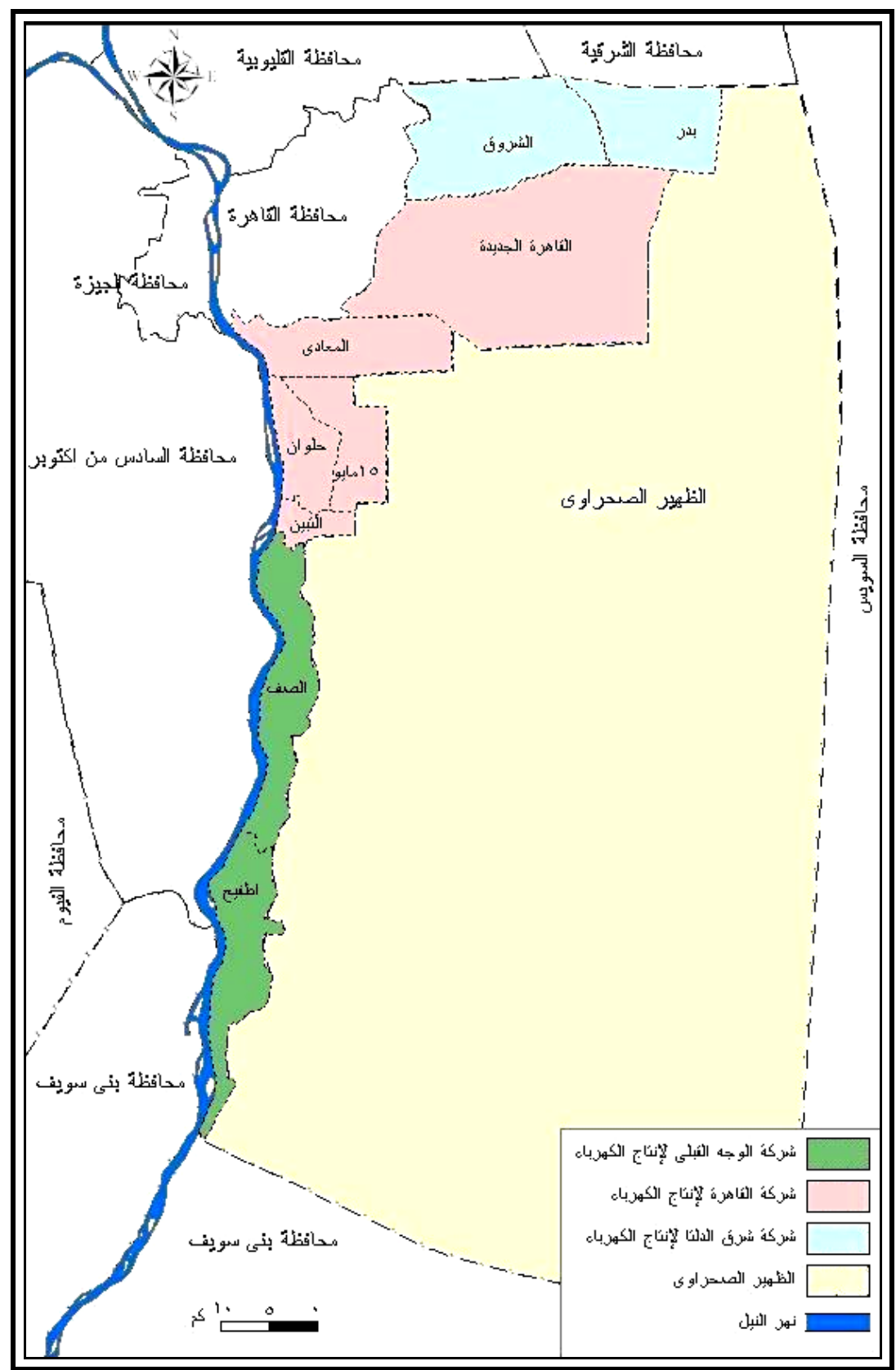

شكل (1) : النطاق الجغرافى لشركات إنتاج الطاقة الكهربائية

ونفوذ كل شركة فى محافظة حلوان ^ . . بام.

$(r \leq 1)$ 
أولاً : التوزيع الجغر افى لمحطات توليد الطاقة الكهربائية بمنطقة الدراسة : يعتمد توليد الكهرباء فى منطقة الدراسة على التوليد الحرارى: الغازى، والبخارى، والدورة المركبة(')، وتخلو منطقة الدراسة من التوليد المائى وكذلك من الطاقة الجديدة والمتجددة (طاقـة الرياح)، ولكنها تشـهـ منذ عام ^ . . rم إنشـاء أول محطة للطاقة الثمسية فى مصر لتوليد الطاقة الكهربائية بمنطقة الكريمات ولم يتت الانتهاء منها

ويتضح من الجدول (1) وتتبع الثكل (Y) أن منطقة الدراسة تضم ست محطات لتوليد الكهرباء، جميعها حرارية. وتضم هذه المحطات 9 و وحدة توليد، وتبلغ قدرتها

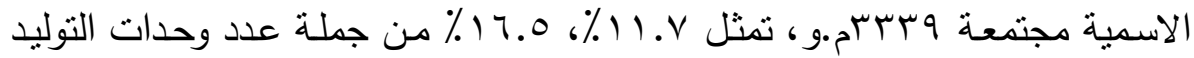

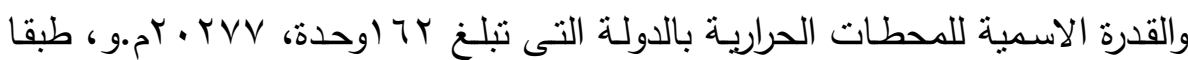

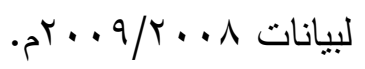

وتتوزع هذه المحطات على شكل محور طولى يمتد على نهر النيل (الضفة الثرقية) الحد الغربى لمنطقة الدراسـة؛ وتتوزع على ثلاثة مواقع جغرافية هىى منشأة ناصر ، وحلوان الثرقية، والكريمات (من أعمال مركز أطفيح).

(1) المحطة الغازية: محطة لإنتاج الكهرباء الحرارية، وتدار توربينامًا بالغاز الطبيعى أو السولار.

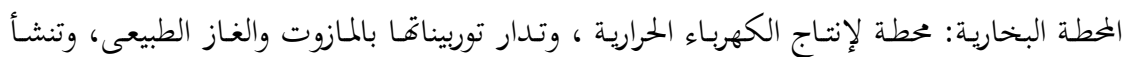

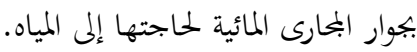


المططة المركبة: محطة لإنتاج الكهرباء الحرارية تم إدخال نظام توليد طاقة إضافية للاستفادة من عوادم الغازات. 


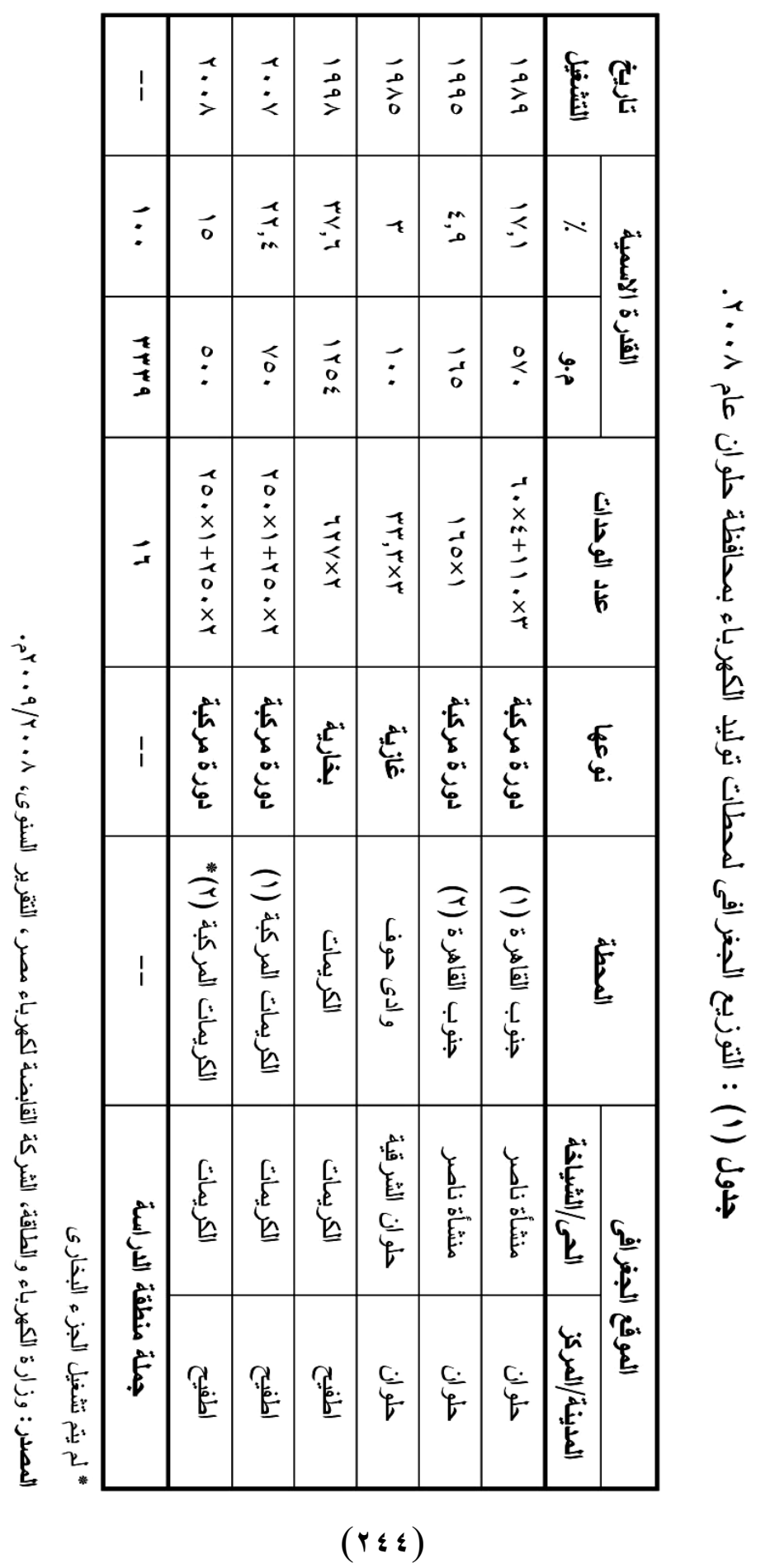




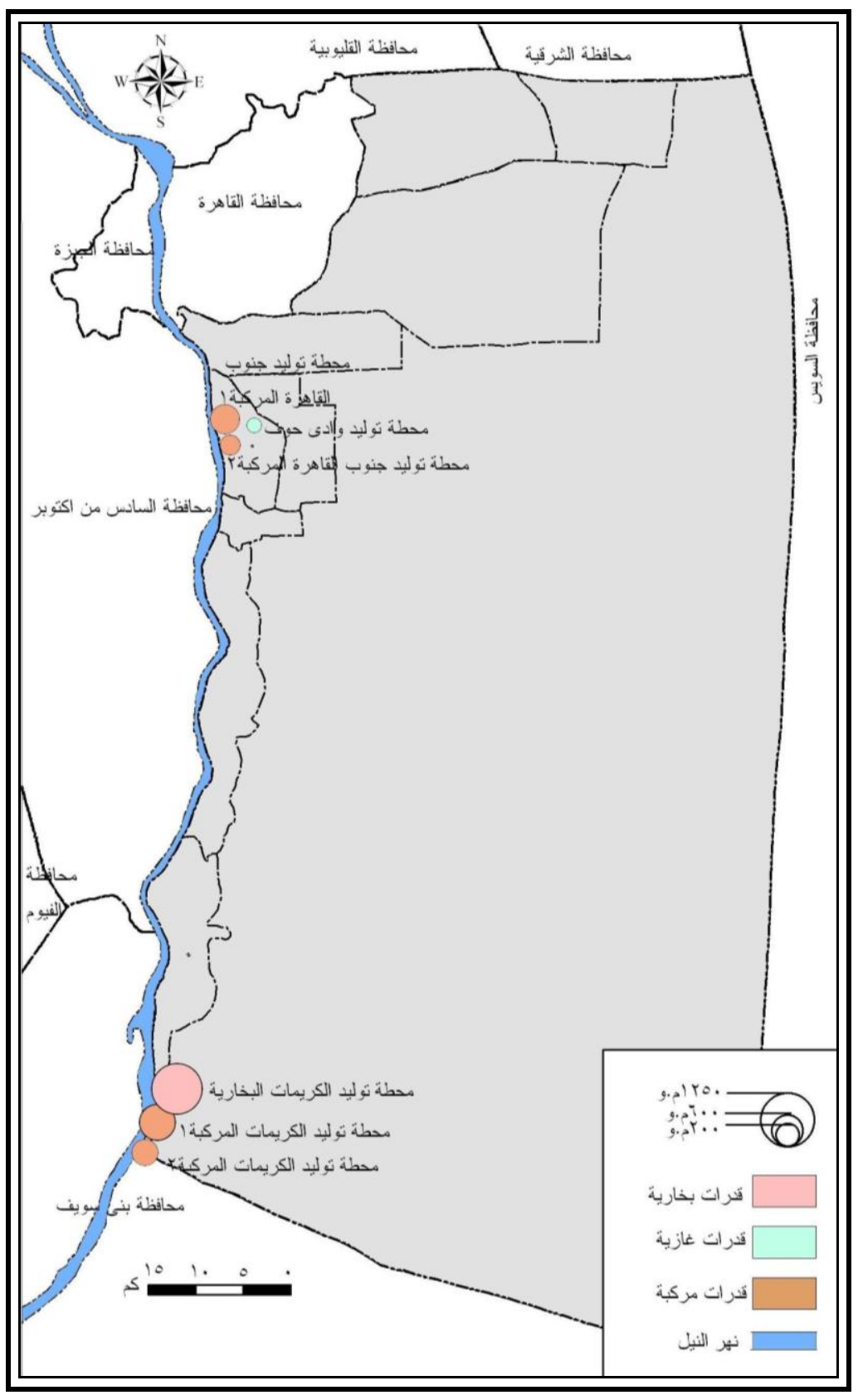

شكل (Y) : التوزيع الجغرافى لقدرات محطات توليد الكهرباء

فى محافظة حلوان عام ^ . . بم.

$(r \leq 0)$ 
والملاحظ أن هذه المحطات تركزت جغرافيا فى منطقتين: المنطقة الأولى: توجد شمال مدينة حلوان، قريبا من مراكز الأحمال داخل نطاق

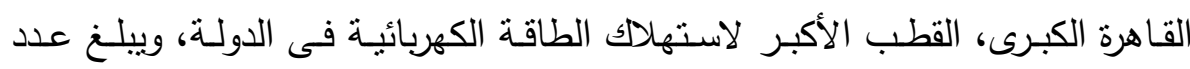
المحطات فى هذة المنطقة ثلاث محطات قدرتها الاسمية المركبة هبم م.و أى هץ \% من القدرات الاسمية المركبة بمحافظة حلوان أى ربع القدرة الأسمية المركبـة، وتعد محطـة جنوب القـاهرة المركبـة (1) أكبر محطـات هذه المنطقة حيث تبــغ قدرتها الاسمية المركبة • oV م.و ، بينما تعد محطة وادى حوف اصغرها وتبلغ قدرتها . 1.

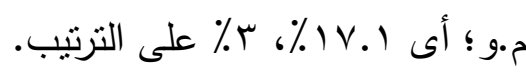

وأما المنطقة الثانية : فتقع فى اقصى جنوب محافظة حلوان بالكريمات ويوجد بها ثلاث محطات وهى: محطة الكريمات البخارية، ومحطة الكريمات المركبة (1)، ومحطة الكريمات المركبة (r)، حيث تعد محطة الكريمات البخارية أكبر محطة فى

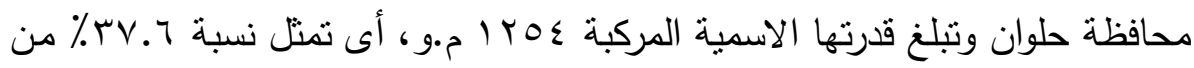
القدرات الاسمية المركبة بمنطقة الدراسة.ونتتاول الجزء التالى هذه المحطات بالدراسة والتعرف على ملامحها الجغرافية على النحو التالى:

\section{أ- محطة جنوب القاهرة المركبة (1) :}

تقع المحطة بالمنطقة المحصورة بين ترعة الخشاب ونهر النيل بشياخة منشأة

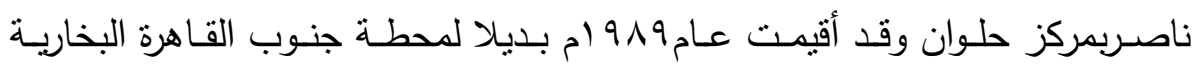
(صورة ()، وذلك فى إطلار عمليات الإحلال والتجديد التى تقوم بها وزارة الكهرباء لتحسين كفاءة التشغيل، وتحقيق وفرات اقتصـادية من خلال تقليل تكلفة الوقود التى تعانى مصر من الندرة فيه. 


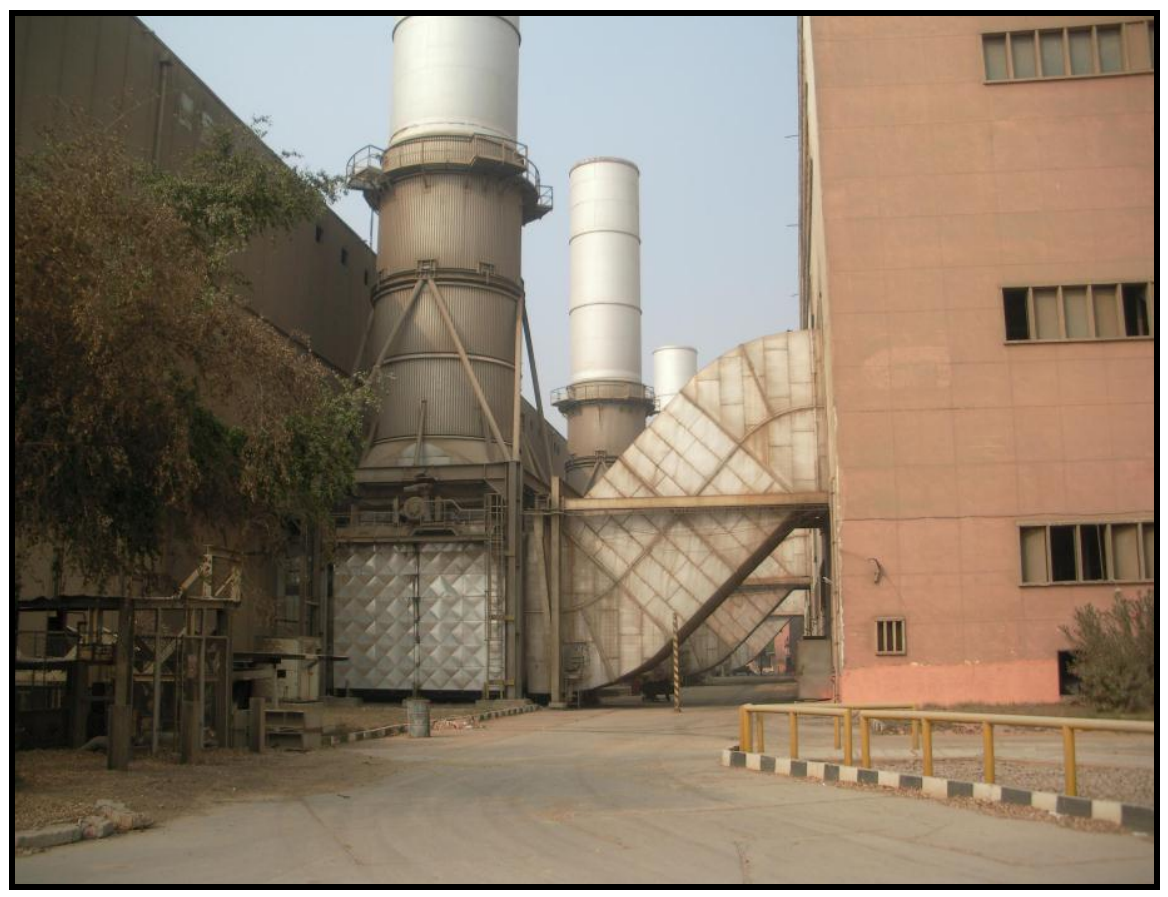

صورة (1) : محطة توليد كهرباء جنوب القاهرة المركبة إإلى يمين الصورة المبنى القديم للمحطة البخارية والتى تم تحويلها للعمل بنظام الدورة المركبة.

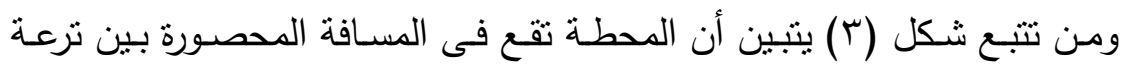

الخشـاب ونهر النيل، وتشـخل المحطة مسـاحة ع ؟ فدانا مشـاطرة مـع محطـة جنوب القاهرة المركبة (Y)، وتقع المحطة بالقرب من الكتلة السكنية بعزبة الوالدة وعلى مقربة وهية من المنطقة الصناعية بحلوان، حيث يجاورها مصنع النصر للسيارات، وشركة حلوان للصناعات الهندسية، ويعد هذا الموقع مناسب حيث يقع فى منصرف الرياح، ونتيجة

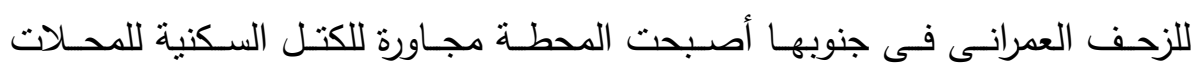
العمرانيـة وأهمهاعزبـة الوالدة التى تقع فى جنوبها وتتسبب المحطة فى تلويث بيئة المنطقة بصفة عامة. 


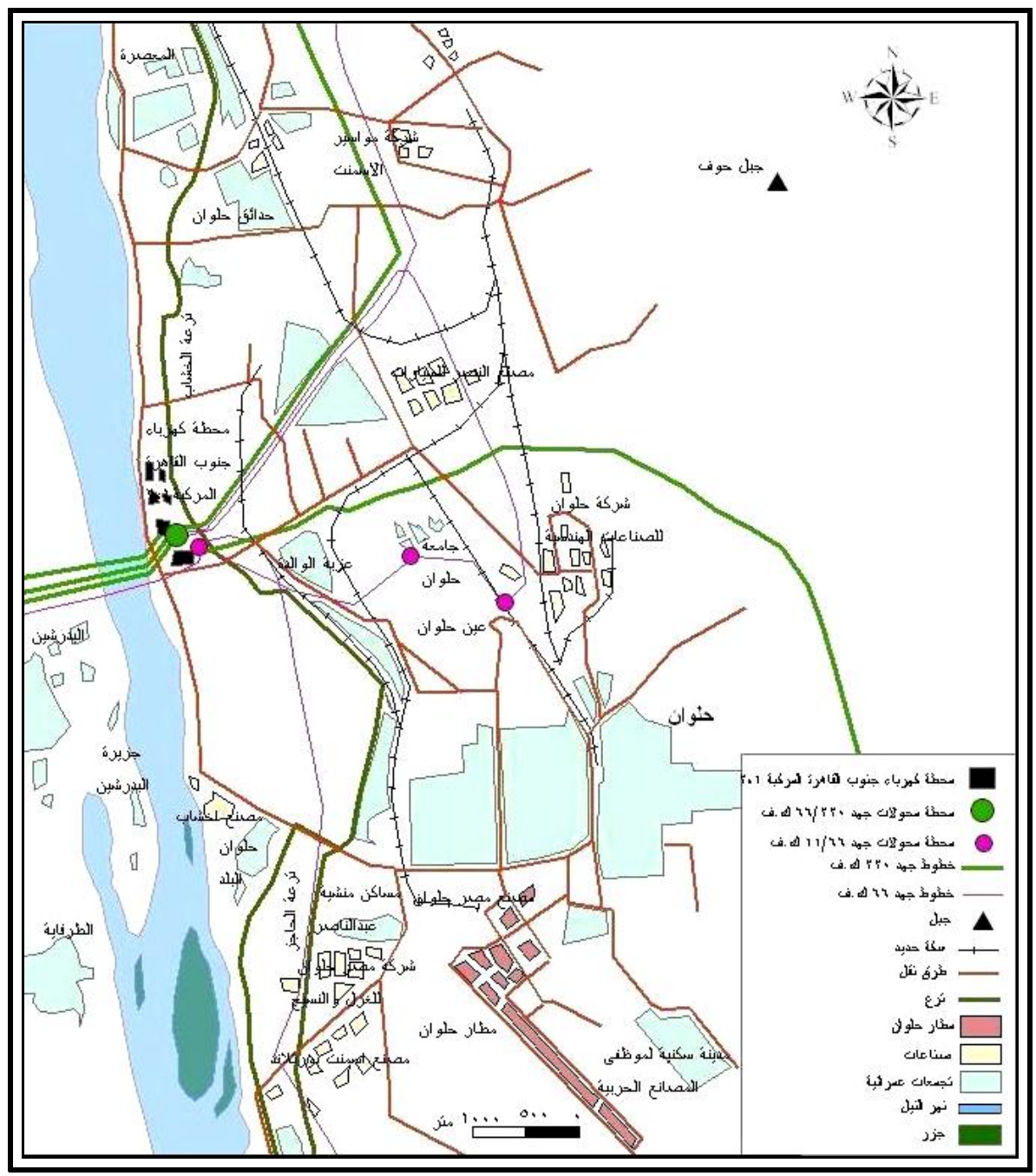

المصدر: المساحة العسكرية لوحة حلوان مقياس (:. . .0مب، عام 919 ام.

$$
\begin{aligned}
& \text { شكل (r) : الموضع الجغرافى لمحطتى جنوب القاهرة }
\end{aligned}
$$

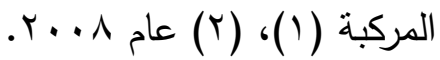


وقد تم تشغيل المحطة فى يونيو 9 وام، بإضـافة وحدتى توليد غازية قدرة كل منها • (1 11 ميجاوات، وفى أغسطس من العام نفسـه تم إضـافة وحدة التوليد الغازيـة

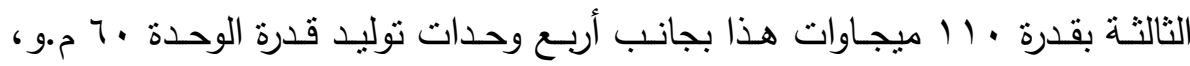

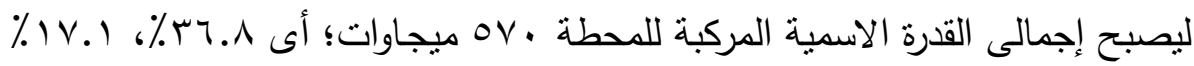

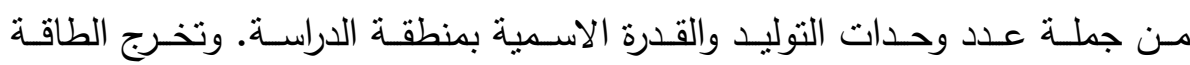
الكهربائية المولدة من المحطة على جهد 11 لك.ف، ولهذا توجد محطة محولات مجاورة لمحطة التوليد لرفع الجهد إلى . . Y ك.ف؛ حيث تتصل بشبكة الجهد العالى • r T.ف لتغذية المناطق المختلفة بالكهرباء.

\section{ب- محطة جنوب القاهرة المركبة (r) :}

تقع هذه المحطة بجوار محطة جنوب القاهرة المركبة (1) وتتشاطرها فى المساحة

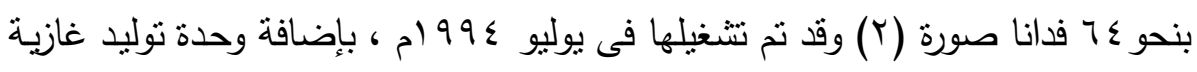
قدرتها • (1 11 ميجاوات، وفى سبتمبر من العام نفسه تم إضافة وحدة نوليد بخاريـة بقدرة

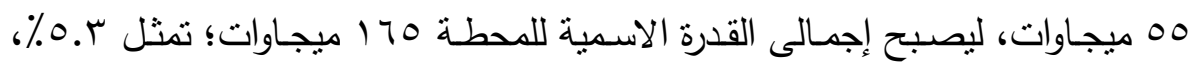

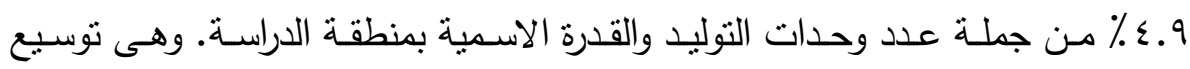
لمحطة جنوب القاهرة المركبة (1) لمواجهة الأحمال الكهربائية والتوسع فى الطلب عليها فى ظل النمو العمرانى المطرد فى جنوبها.وتستهلك المحطة كمية من الغاز الطبيعى،

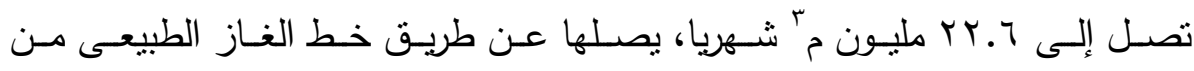

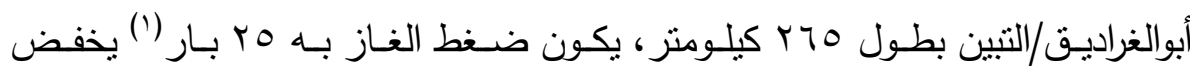

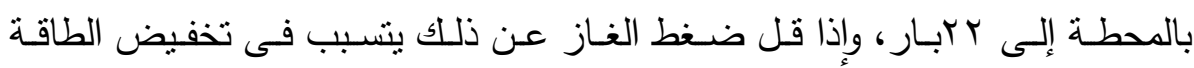
الكهربائية المولدة من الوحدات الغازية والبخارية(؟).

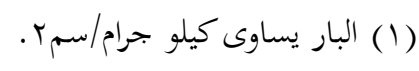

(Y) محطة كهرباء جنوب القاهرة المركبة (r)، إدارة الشئون الفنية والتدريب والمتابعة، بيانات غير منشورة،

$$
\text { pros }
$$




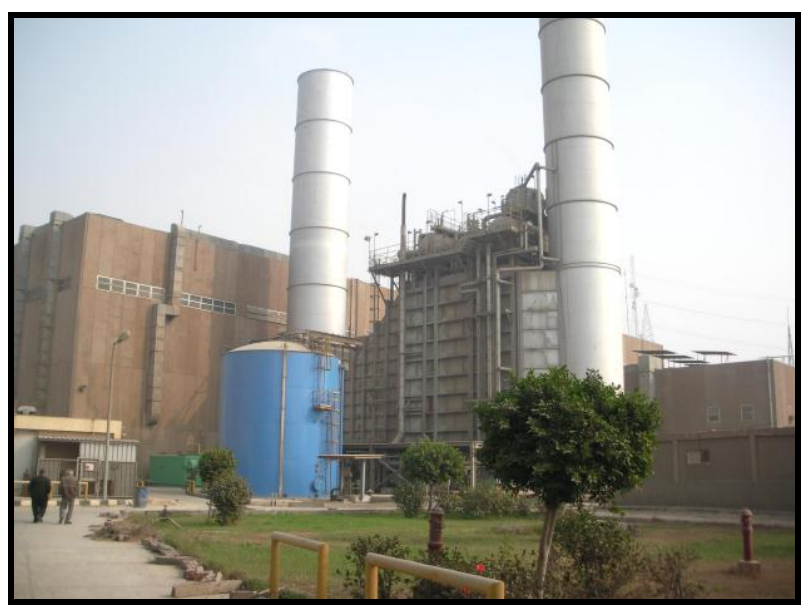

صورة (r) : محطة كهرباء جنوب القاهرة المركبة (r).

ج- محطة وادى حوف :

تقع محطة وادى حوف بشياخة حلوان الثرقية وهى تتوسط المنطقة الصناعية بـوادى حـوف، وتقوم بتغذيـة المصـانع والثـركات الصـناعية المحيطـة بحاجتهـا مـن الطاقـة الكهربائيـة وأهـم هـذه المصـانع: شـركة النصـر لصـناعة المواسـبر ، والنصـر للسيارات، والمصـانع الحربيـة، ومصنـع سيماف لعربـات السـكك الحديديـة، ومصـانع الطائرات، والنقل الخفيف، والثـركات الاستثمارية مثل: اليو مصر ، وايكون وودمان؛ أى أن المحطة تقع وسط سوق استهلاكها.

وهـى مـن المحطـات الغازيـة، ثنائيـة التشـغيل تـدار توربيناتهـا بالغـاز الطبيعى

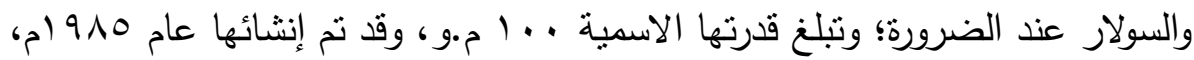
بعد عمل الدراسات الفنية والاقتصادية من قبل هيئة كهرباء مصر وأسند لشركة بروان

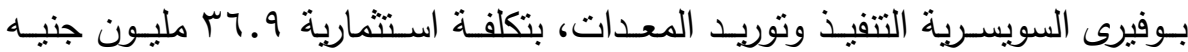
مصرى، وتقدر قيمنها الحالية بحوالى ع. Y. مليون جنيه مصرى ('). (1) وزارة الكهرباء : سجل مشروعات الطاقة الكهربائية في الفترة من اله ام إلى ا99 (م) الجزء الأول،

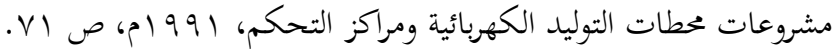




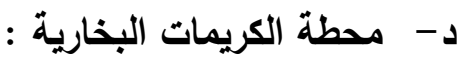

نظرا لأن المحطة هى أكبر محطات منطقة الدراسة فيحاول الطالب أن يتتاولها بشـئ من التفاصيل حيث تقع المحطة بالكريمات (من أعمـال مركز أطفيح) على

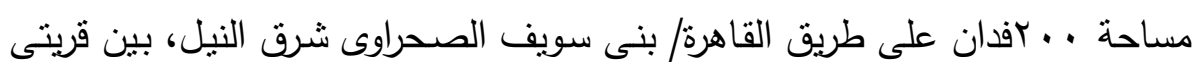
الكريمات شمالا ودير الميمون جنوبا (شكل ع وصورة r).

وقد أقيمت محطة كهربـاء الكريمات بمنطقة ربفيـة، تجمع بين بيئة نهر النيل الذى يقع فى غربها والبيئه الصحراوية التى تقع فى شرقها، وتم اختيارموقع محطة

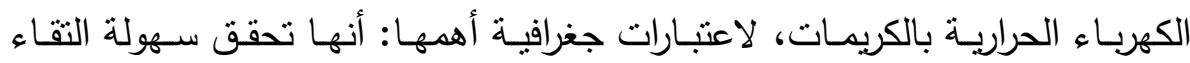
الموضـع الجغرافى بمسـارات خط أنابيب الغـاز الطبيعسى لضـمان تـوفير احتباجـات المحطة من الغاز الطبيعى وخطوط نقل الكهرباء للجهد العالى، بما فى ذلك تأمين إمكانية ربط المحطة بالثبكة الكهربائية الموحدة ،زد على ذلك المشروعات التتمويـة الجارية فى منطقة الصف وأطفيح على الهوامش الشرقية لمنطقة الدراسة (الاستصلاح الزراعى والتوسـع الأفقى فى الأرض الزراعيـة) وقربها مـن المنطقة الصناعية بينى سويف الجديدة، فالمحطة اقيمت وسط منطقة سوق الاستهلاك وكذلك توفر المياه اللازمة للتبريد وتعويض فاقد مياه الغلايات.

وتحتاج المحطة كميات من المياه تقدر بنحو و9 ألف مّ فى الساعة يتم سحبها من النيل بواسطة طلمبات شفط المياه (صورة ع)، ثم تتقل بواسطة مواسير قطرها • . كميـة ميـاه نسـبتها هـ 1 \% للتتقيـة والمعالجـة للتخلص مـن الثـوائب والمـواد العالقـة وتنتخدم فى عملية توليد البخار (').

$$
\text { (1) شركة الوجه القبلى لإنتاج الكهرباء: تقرير غير منشور،القاهرة، • 1 • بم. }
$$




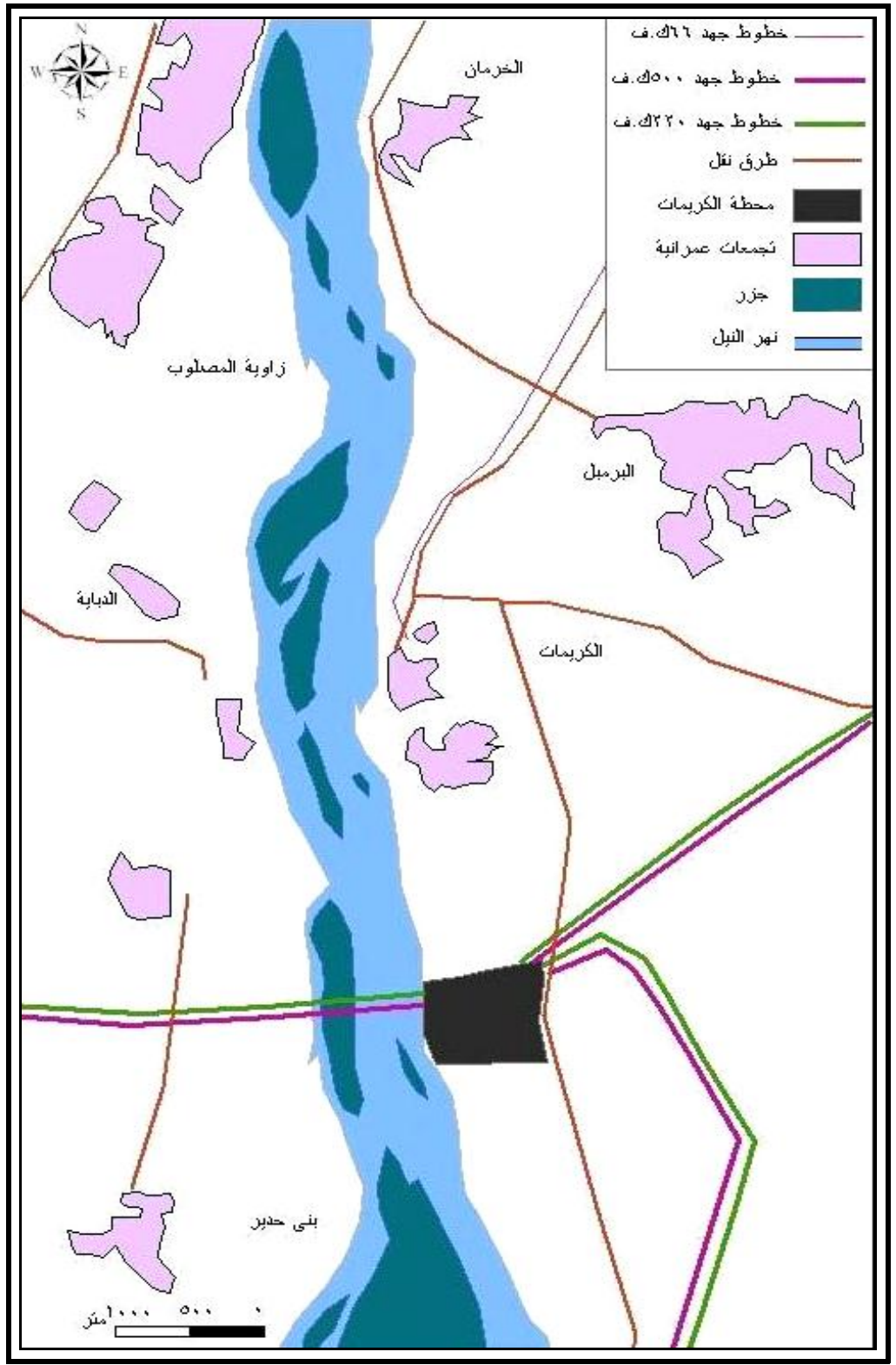

المصدر: الهيئة المصرية العامة للمساحة، لوحة الوسطى، مقياس (:....0 طبعة 990 1م.

شكل (؟) : الموضع الجغرافى لمحطتى الكريمات البخارية

$$
\text { الكريمات المركبة عام } 1 \text {. . بام. }
$$

$(r \circ r)$ 


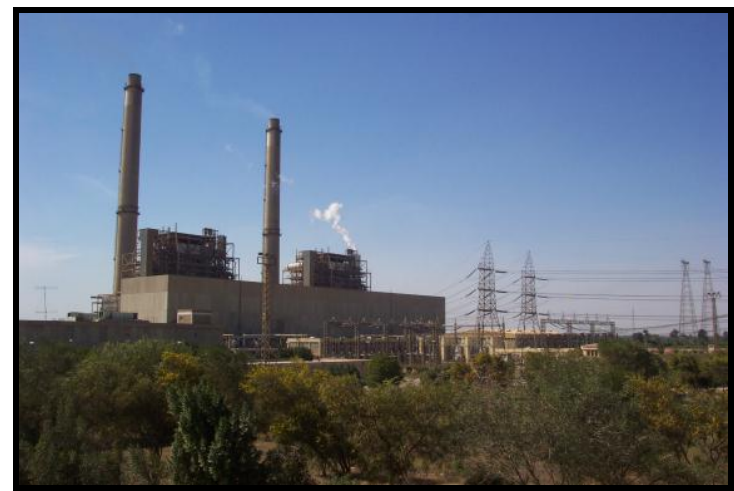

صورة (r) : محطة الكريمات البخارية، • 1 • م.

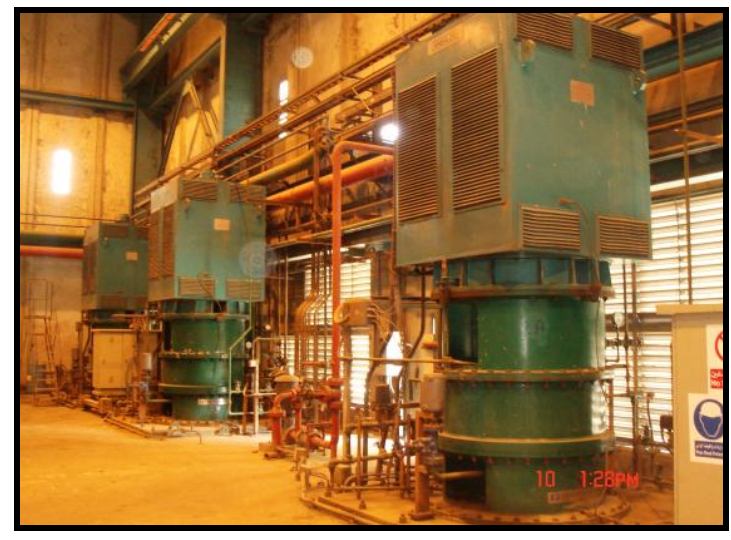

صورة (ع) : طلمبات شفط المياه من نهر النيل(').

وتتم عمليات تتقيـة المياه بإزالة عسر المياه والتخلص من جميع المواد الذائبة

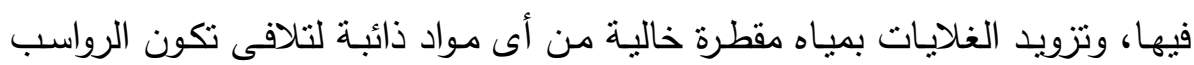
على سطح المراجل البخاريـة الخاصـة بالتسخين وإنتاج مياه نقية خالية من الأمـاه لتستعمل فى الغلايات(؟).

(1) هذه الصور تم التقاطها أثناء الدراسة الميدانية لمحطة الكريمات البخارية والمركبة بتاريخ • (1-9 - • ( ب م. (r) محمد محمود ابراهيم الديب، الطاقة فن مصر - دراسة تحليلية فن اقتصاديات المكان، مكتبة الأبخلو

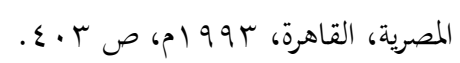

$(r \circ r)$ 
وقد خصصت وكالة التتمية الدولية الأمريكية، عام 910 (م، منحة لدراسـة الجدوى الهندسية والاقتصـادية لإنشـاء محطـة كهربـاء حراريـة بقدرة . . Y I م.و بموقع الكريمات، وقد تم المفاضلة بين خمسـة مواقع جغرافية من المواقع البديلة

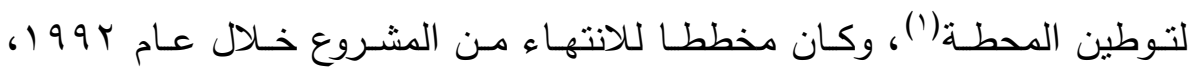
بتكلفة إجمالية بلغت 9 91 مليون دولار أمريكى بأسعار 9 امج(؟).

وقد تم تشغيل المحطة عام و99 ام، حيث يستخدم المازوت كوقود فى توليد البخار المستخدم فى تشـيل المولد البخارى، وتضم المحطة عدد وحدتين توليد

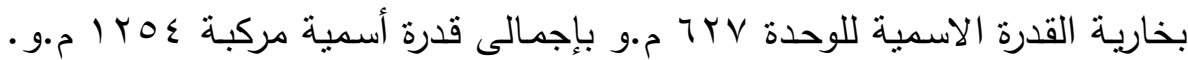

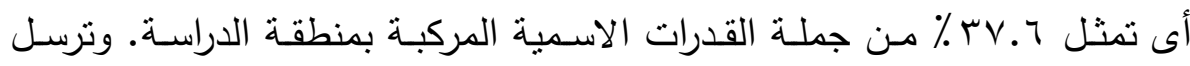
محطـة الكريمات البخاريـة أكبر محطات منطقة الدراسـة كميـة طاقـة مولدة تقدر بنحو هبr9 مليون ك.و .س إلى الثبكة الكهربائية الموحدة عن طريق وقوعها كحلقة وصل للجهد الفائق والعالى حيث ترتبط مـع محطلة محولات التبين جهد . . . . ك.ف، وكذلك ترتبط مـع محطـة محولات غرب القاهرة بعد عبور شبكة الجهد الفائق والعالى نهر النيل الى الغرب، حيث ترتبط شمالا مع محطة محولات غرب القاهرة، وتزتبط جنوبا مع محطة محولات سمالوط. (1) هذه المواقع هى: البحيرة، شمال القاهرة، دمياط، الكريمات، الزعفرانة؛ ووقع الاختيار على الكريمات.

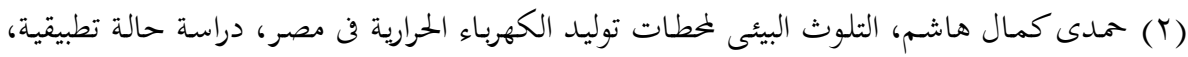

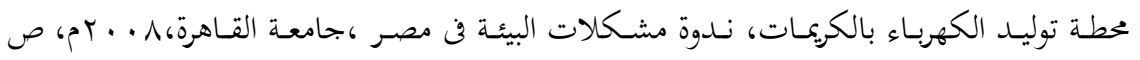


تقع بجوار محطة الكريمات البخارية، وتشغل مساحة . . ب فدان للمحطتين معا، وقد بدأ العمل فى تتفيذ محطة الكريمات المركبة (1) في منتصف ابريل هـ م. . بم،

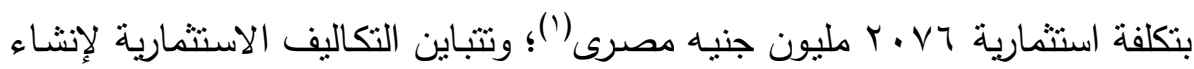
محطات توليد الطاقة الكهربائية طبقا لعوامل مختلفة وتتراوح بين ه. • إلى 9 . • مليون دولار لكـل ميجـاوات مـن القدرة الكهربائيـة المطلوبـة حسـب نـوع المحطــة والتقنيـة المستخدمة فيها وموقع تركيبها (؟).

وتم تشغيل المحطة فى فبراير V . . Y م، وتتكون من وحدتى توليد غازية قدرة كل

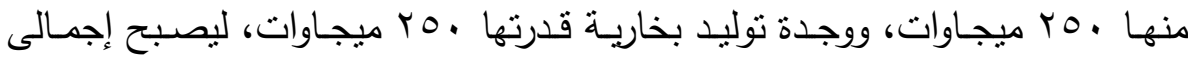

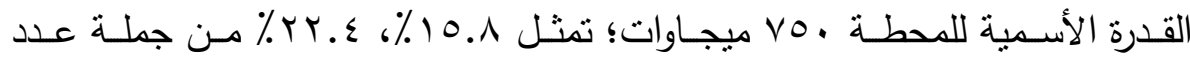
وحدات التوليد والقدرة الأسمية بمنطقة الدراسة.

\section{و - محطة الكريمات المركبة (r) :}

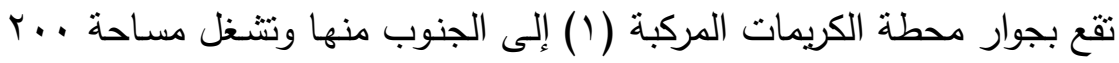

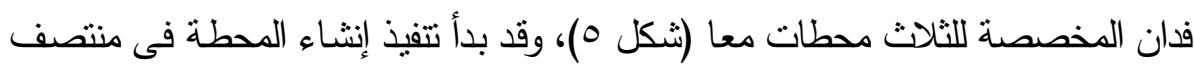

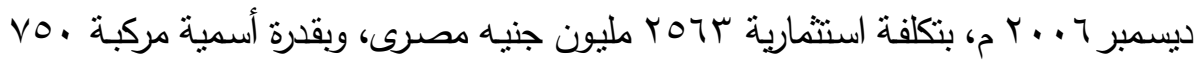
ميجاوات، مكونة من وحدتى توليد غازبة قدرة كل منها . P ميجاوات، ووحدة توليد بخارية

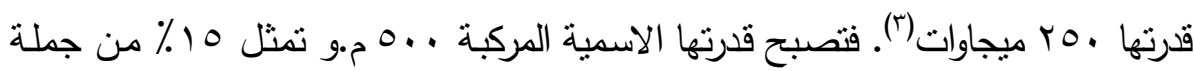
القدرات الاسمية بمحافظة حلوان. وترتبط المحطة بالثبكة الكهربائية الموحدة، من خله مله

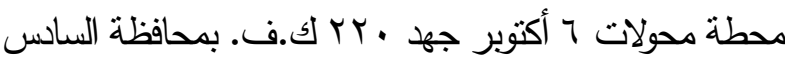

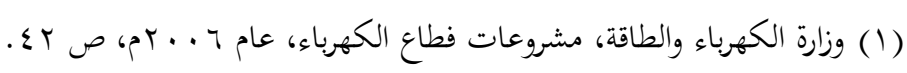

(2) Proceeding of The Expert Group Meeting on The Privatization of Electric Power Sector, Beirut, 1-4 November, 1999, United Nations, P. 16.

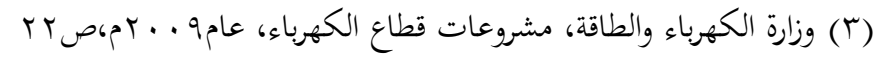


من أكتوبر ، عن طريق خط هوائى مزدوج الدائرة طوله 90 كيلومترا؛ بينما ترتبط مـع محطة محولات شرق القاهرة جهد · ب ك.ف بمحافظة القاهرة، بخط هوائى مزدوج

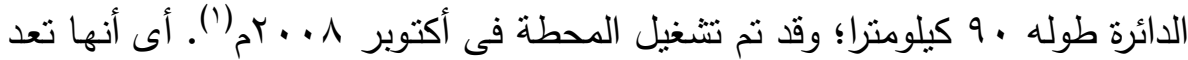
حلقة وصل بين غرب النيل (محافظة السـادس من أكتوبر) وشمال شـرق مخافظة

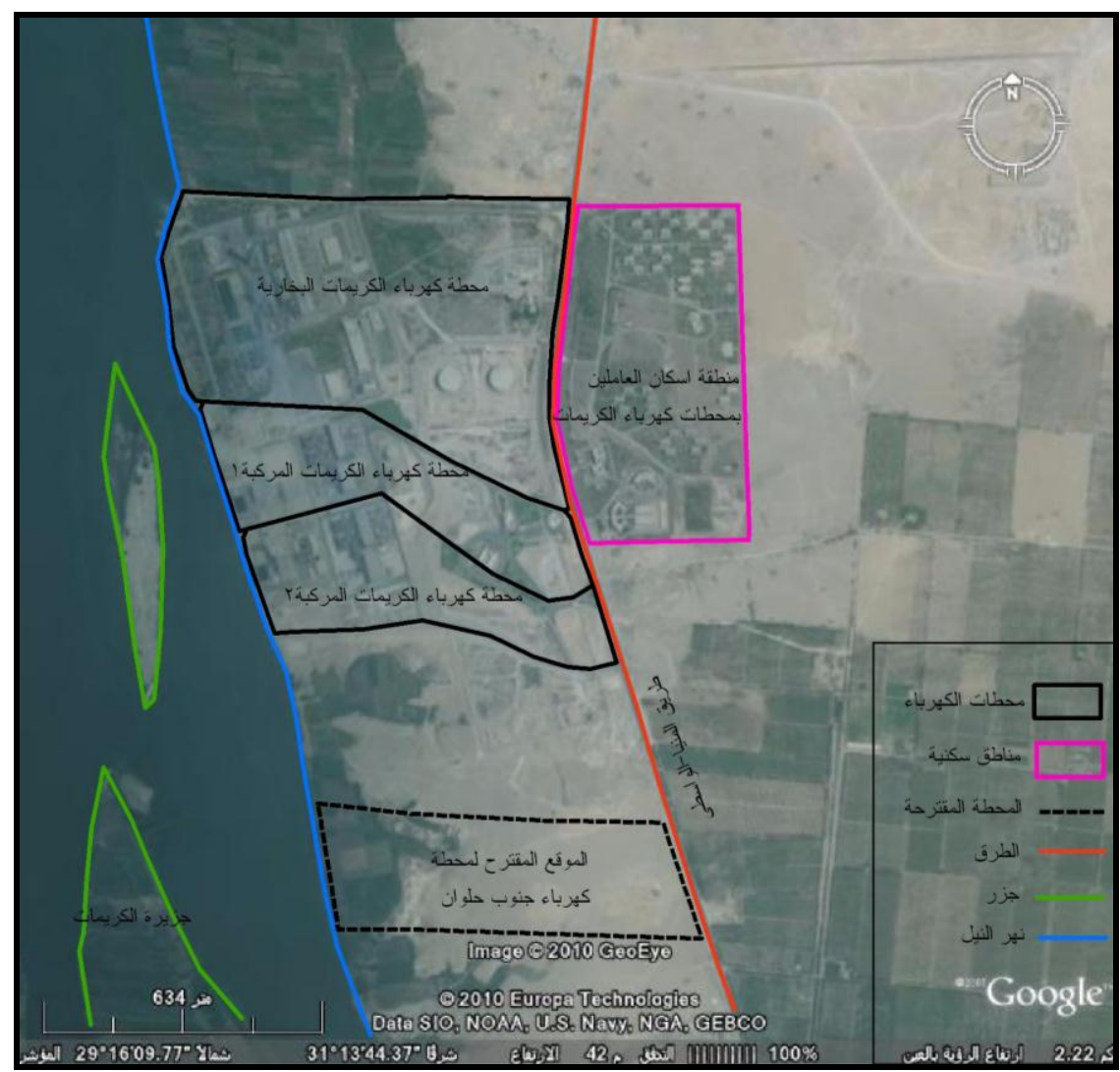

Google Earth لمصدر : برنامج

شكل (0) : الموقع والموضع الجغرافى لمحطة كهرباء الكريمات؟.

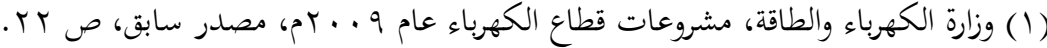

$(r \circ \neg)$ 
وقامت شركة كهرباء الوجه القبلى، بشراء قطعة أرض جنوب محطة الكريمات المركبـة (Y) بـالقرب من قريـة دير الميمون (شكل T)، لإنشـاء محطـة توليد كهربـاء جنوب حلوان لمواجهة الطلب المنزايد على الكهرباء فى المستقبل (').

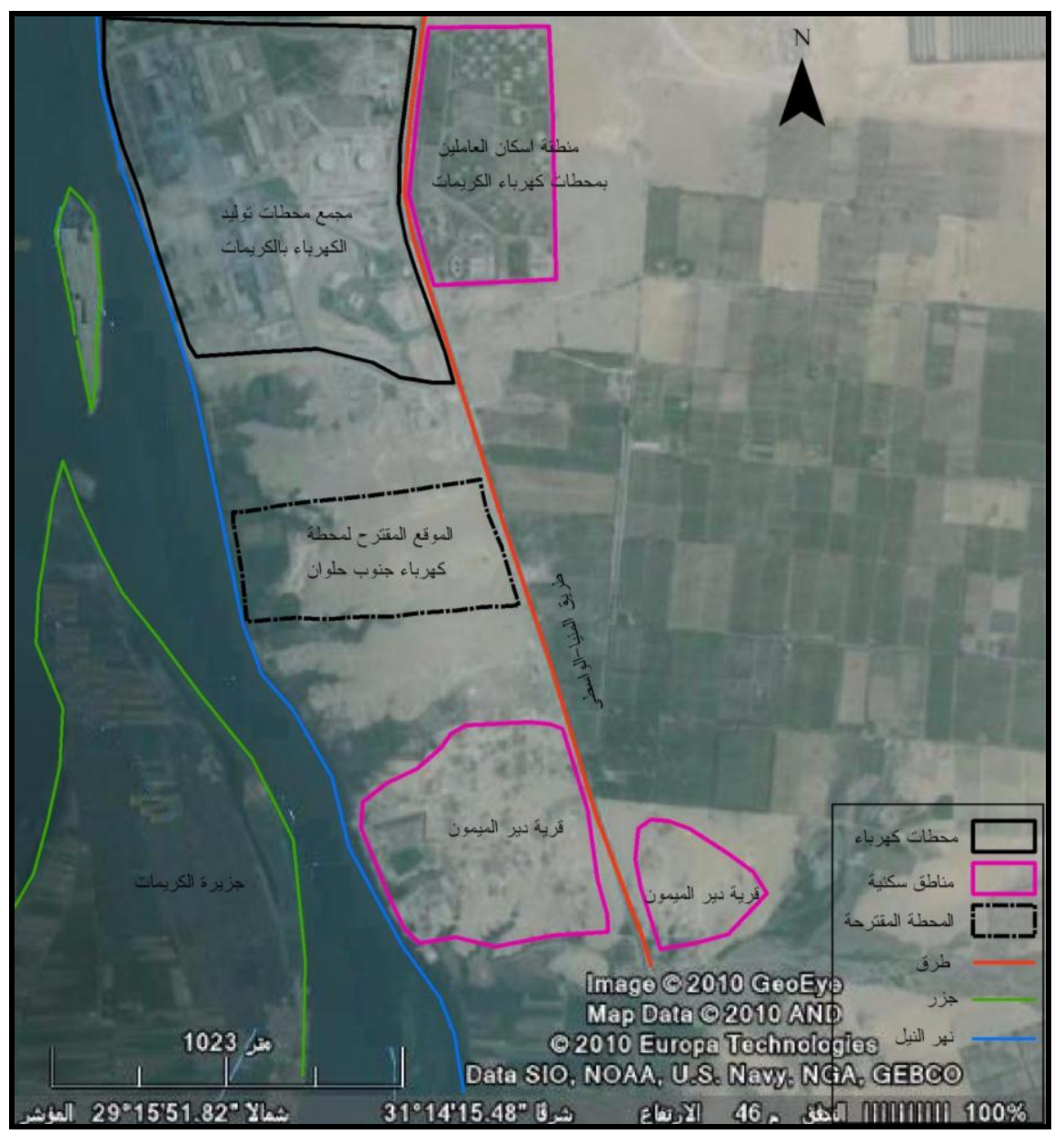

Google Earth المصدر : برنامج

شكل (؟) : الموقع والموضع الجغرافى المقترح لمحطة توليد كهرباء جنوب حلوان.

(1) شركة الوجه القبلى لإنتاج الكهرباء: الدراسات الأولية لإنشاء العططة، بيانات غير منشورة، • ا ب بم. $(r \circ V)$ 
وقد توطنت المحطـات الحراربـة بمنطقـة الدراسـة بـالقرب مـن مراكز الأحمـال (مراكز

الاستهلاك) لتقليل تكلفة النقل وفقد الكهربـاء عبر الثبكة إلى أدنى حد ممكن. يتبين من العرض السابق للتوزيع الجغرافى لمحطات توليد الطاقة الكهربائية بمنطقة الدراسة الملاحظات

1- تركزت محطات منطقة الدراسة جغرافيا فى منطقتين: الأولى فى شمال مدينة حلوان، بالقرب

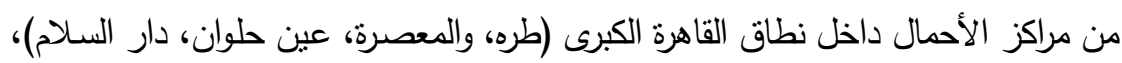
والثانية جنوب مدينة أطفيح بالكريمات بالقرب من المنطقة الصناعية بينى سويف الجديدة

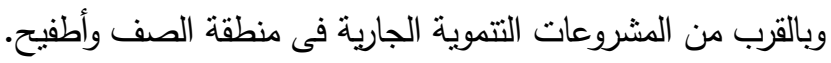

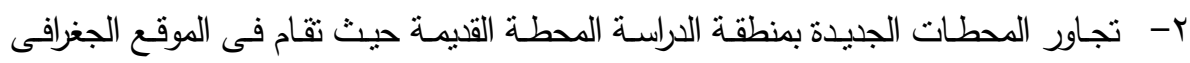

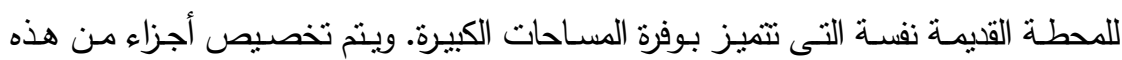
المساحات لإنشاء المحطات الجديدة، كما حدث لمحطة جنوب القاهرة بمنشأة ناصر التى أقيم

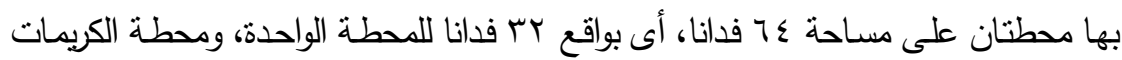

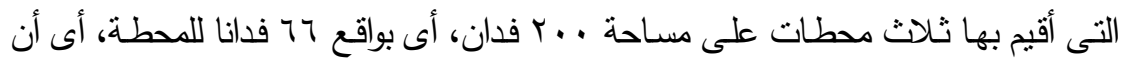

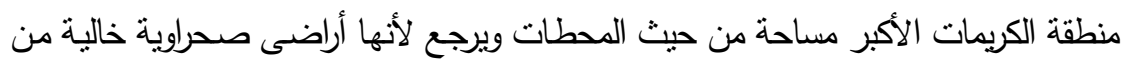

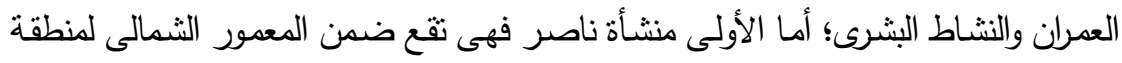

ثانياً : القدرة الاسمية المركبة والحمل الأقصى ('):

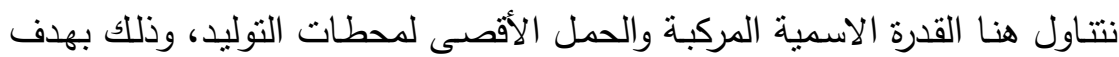
التعرف على القدرة الفعلية وكميات الكهرباء التى تتتجها محطات التوليد بمنطقة الدراسة

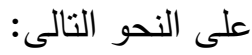

(1) القدرة الاسمية المركبة : هى القدرة التصميمية لوحدات التوليد المركبة بالمحطة مقيسة بالكيلووات/ساعة

$$
\text { بالنسبة لتوليد الكهرباء }
$$

القدرة الفعلية : هى أقصى قدرة لوحدات التوليد المركبة للمحطة يمكن الوصول إليها.

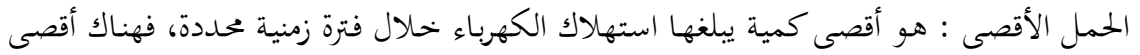
حمل يومى أو شهرى أو سنوى معبرا عنه بالكيلووات أو الميجاوات. 


\section{(أ) القدرة الاسمية المركبة :}

تتمو قدرات محطات أية منظومة كهربائية وفقا لحجم الطلب على الكهرباء. كما تهدف أى زيادة فى قدرات التوليد الوصول إلى درجة اعتمادية عاليـة لضمان استمرار

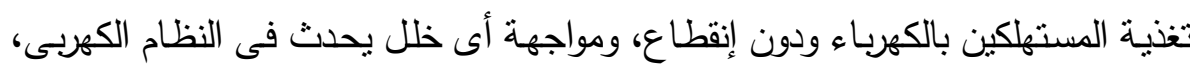

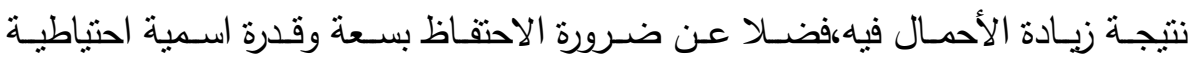

$$
\text { لأغراض الطوارئ(') }
$$

جدول (r) : القدرة الاسمية المركبة لمحطات توليد الكهرباء

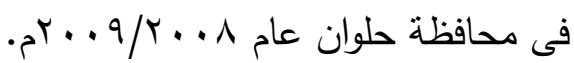

\begin{tabular}{|c|c|c|c|c|c|}
\hline $\begin{array}{c}\% \\
\text { محطات } 1 \text { مصر }\end{array}$ & 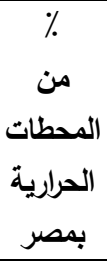 & محن & محن محنظة & الاسمبة المركبة & المتغيرات \\
\hline $0 . r$ & $7 . Y$ & IV.V & rV.T & I Tos & الكريمات البخارية \\
\hline r. & r.V & $1 \cdot .7$ & Tt. & vo. & الكريمات المركبة ا \\
\hline Y.乏 & r.A & $\wedge$ & 18.1 & or. & جنوب القاهرة المركبة ا \\
\hline r.l & T.O & v.l & 10 & $0 .$. & الكربمات المركبة \\
\hline$\because V$ & $\cdot . \wedge$ & r.r & $\varepsilon .9$ & 170 & جنوب القاهرة المركبةץ \\
\hline$\cdot \varepsilon$ & .0 & $1 . \varepsilon$ & r & $1 \ldots$ & وادى حوف \\
\hline $1 \leq . r$ & 17.0 & $\varepsilon \vee .1$ & $1 \ldots$ & و qזس & اجمالى محافظة حلون \\
\hline$r \cdot . r$ & $r \varepsilon .9$ & - & - & $v \cdot \wedge 9$ & اجمالى محطات القاهرة الكبرى \\
\hline AT.r & - & - & - & T. TVV & اجمالى المحطات الحرارية بمصر \\
\hline- & - & - & - & rro.r & اجمالى محطات مصر \\
\hline
\end{tabular}

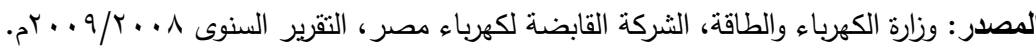

(1) زكى أحمـد مرشـد محمـد، منظومـة الطاقـة الكهربائية في اليمن - دراسـة في جغرافيـة الطاقة، رسـالة دكتوراه، غير منشـورة، جامعـة الـدول العربيـة، معهـد البحـوث والدراسـات العربية، قسم البحـوث

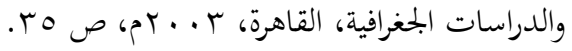




$$
\text { ومن دراسة الجدول (Y) يتضح الملاحظات الآتية: }
$$

1. ت تساهم منطقة الدراسة بنحو ه. 1 ٪ من القدرات الاسمية المركبة لمحطات التوليد الحرارى فى الدولة، وتساهم بنحو r. ـ ا ٪ من إجمالى القدرات الاسمية المركبة

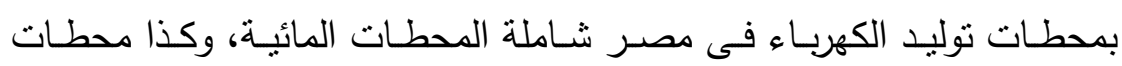

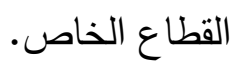
r. بلغت القدرة الاسمية المركبة لمحطات توليد الطاقة الكهربائية بمحافظلة حلوان

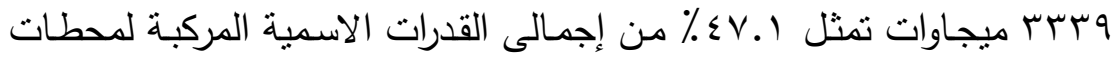

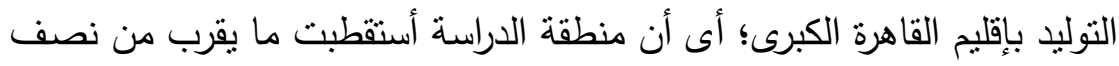
القدرات الاسـية بـالإقليم، وهذا يعكس أهميـة منطقة الدراسـة ومحطـات التوليد

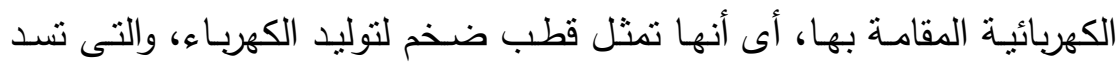
جزء من إحتياجات إقليم القاهرة الكبرى من الطاقة الكهربائية؛ فمنطقة الدراسـة تعد أكبر قطب صناعى فى الدولة حيث تركزت بها معظم الصناعات الثقيلة والصناعات الحربية؛ ولعب ذللك دورا فى ظهور محطات التوليد الضخمة فى قدرتها الاسمية. r. ويتضح من الجدول (r) والثكل (V) أن القدرة الاسمية المركبة لمحطة الكريمات

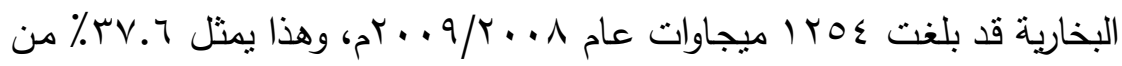
القدرات الاسمية المركبة لمحطات التوليد الكهربى بمنطقة الدراسـة أى أكثر قليلا من التلث، وهى تعد ثانى أكبر المحطات الحرارية المقامة فى الدولة بعد محطة

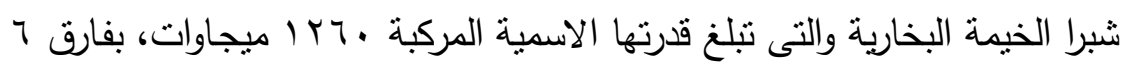
ميجـاوات عن محطة الكريمـات البخاريـة؛ وتمثنل القدرة الاسمية المركبـة لمحطـة

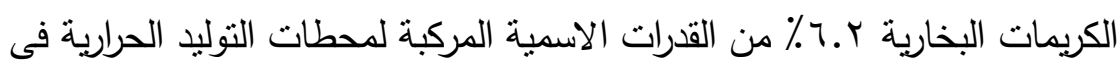
الدولة، ونحو ؟.0\% من جملة القدرات الاسمية لمحطات التوليد بكافة أنواعه. فى حين تمثل V.V. V من مجموع القدرات الاسمية المركبة لمحطات التوليد الكهربائى

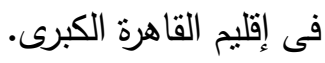




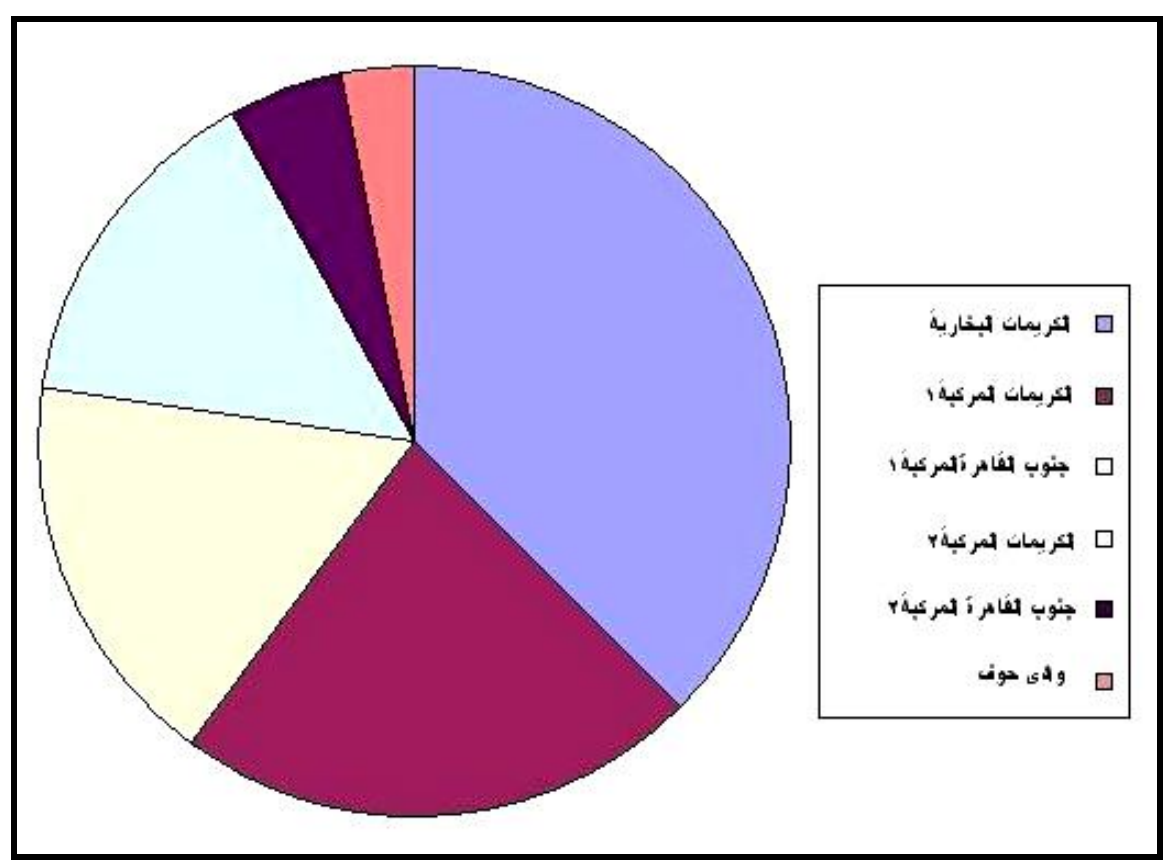

شكل (V) : القدرات الاسمية المركبة لمحطات التوليد

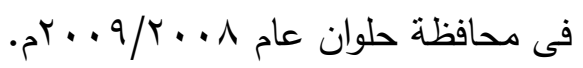

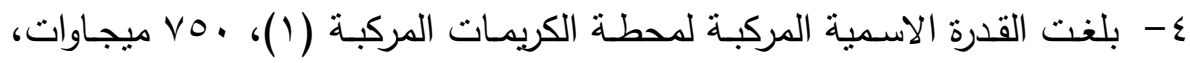

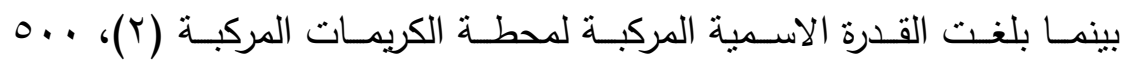

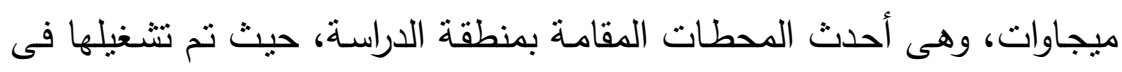
أكتوبر عام ^ . . بام، وإذا اضفنا القدرة الاسمية لمحطة الكريمات البخاريـة مـع

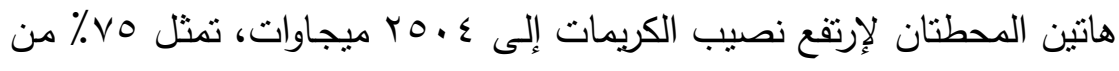
جملـة قدرات منطقة الدراسـة؛ أى أن هذا الموقع الجغرافى (الكريمـات) بمفرده

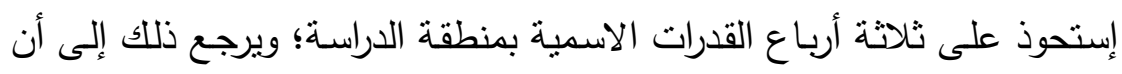

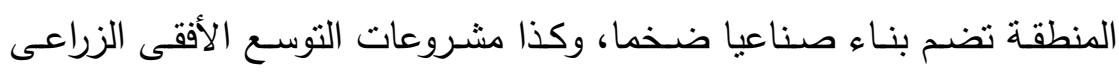
الناهض والنامى الذى تشهده المنطقة. 


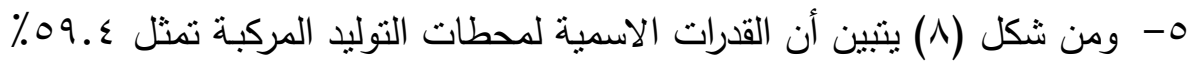
من إجمـالى منطقة الدراسـة، أى مـا يقرب من ثثلاثة أخماس القدرات الاسمية المركبة بالمحافظة؛ وهذا بشبر إلى أن محطات توليد الكهربـاء بمنطقة الدراسـة تستخدم أحدث النظم فى توليد الكهربـاء، فمـن المعروف أن محطـات التوليد المركبة أقل فى استهلاك الوقود.

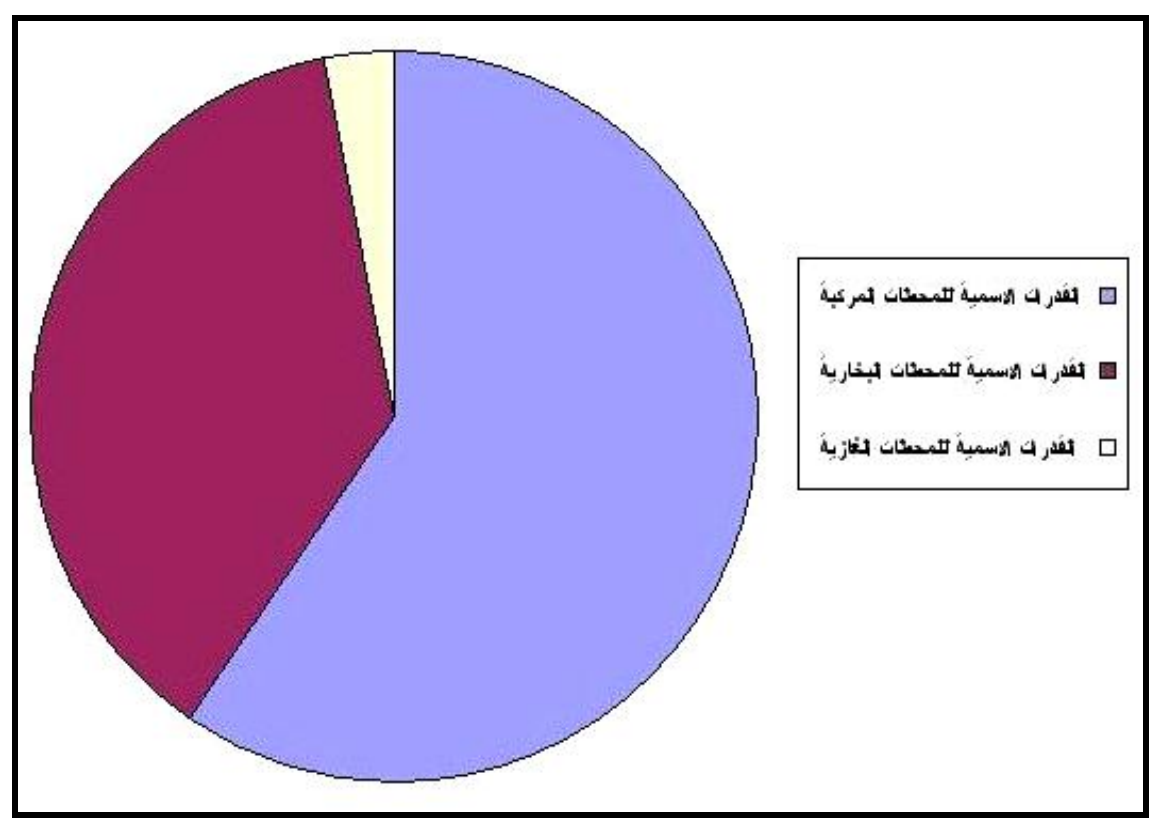

شكل (^) : القدرات الاسمية المركبة لمحطات التوليد

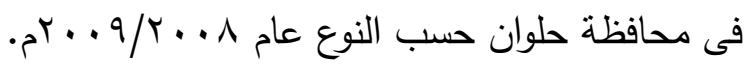

צ- تعد محطة توليد جنوب القاهرة المركبة (1) بمنشأة ناصر (من أعمال حلوان)، هـى ثالت أكبر محطـات التوليد بمنطقـة الدراسـة مـن حيث القدرات الأسـمية المركبة، وهى تتكون من سبع وحدات توليد منها ثناث وحدات توليد قدرة كل منها • 11 ميجاوات (ب × · (1 م.و)، بالإضافة إلى أربع وحدات قدرة كل منها 


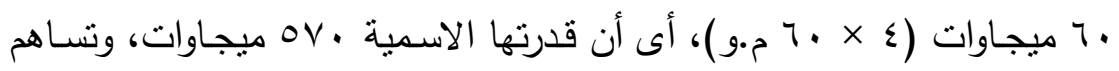

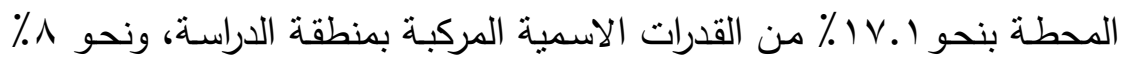
من إجمالى القدرات الاسمية المركبة لمحطات التوليد بإقليم القاهرة الكبرى.

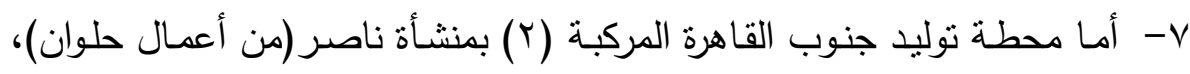
فقدرتها الاسـمية المركبـة 170 ميجـاوات، تمثنل 9.ـ ٪ مـن القدرات الاسـمية المركبة بمنطقة الدراسـة؛ وإذا أضفنا القدرة الاسمية لمحطة توليد جنوب القاهرة

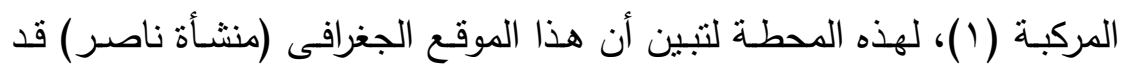

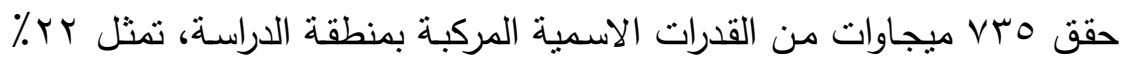

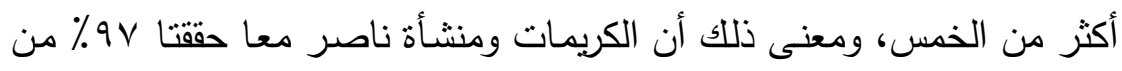

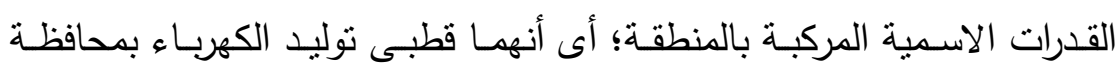

$$
\text { حلوان (شكل 9) } 9 .
$$

1- تعد محطة توليد وادى حوف أصغر محطات التوليد الكهربائى بمنطقة الدراسة وتبلغ قدرتها الاسمية . . 1 ميجاوات وهى تتكون من ثلاث وحدات توليد غازية،

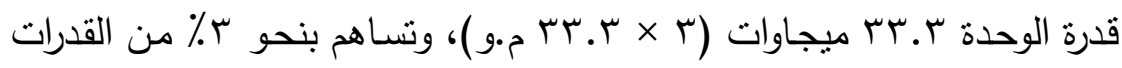
الاسمية المركبة بمنطقة الدراسة.

(ب) الحمل الأقصى : (ب)

من المعروف أن محطات توليد الكهرباء لا تعمل بكامل قدرتها الاسمية المركبة، وذللك للمحافظة على وحدات التوليد بالمحطة من الإهلاك وتوفير وقت للراحة وصيانة

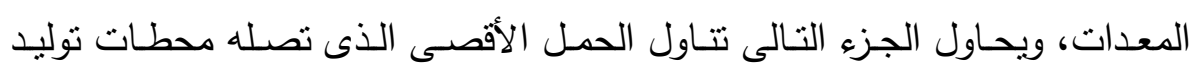
الكهرباء فى محافظة حلوان على مدار شهور العام ويتضـح ذلك من بيانات الجدول 


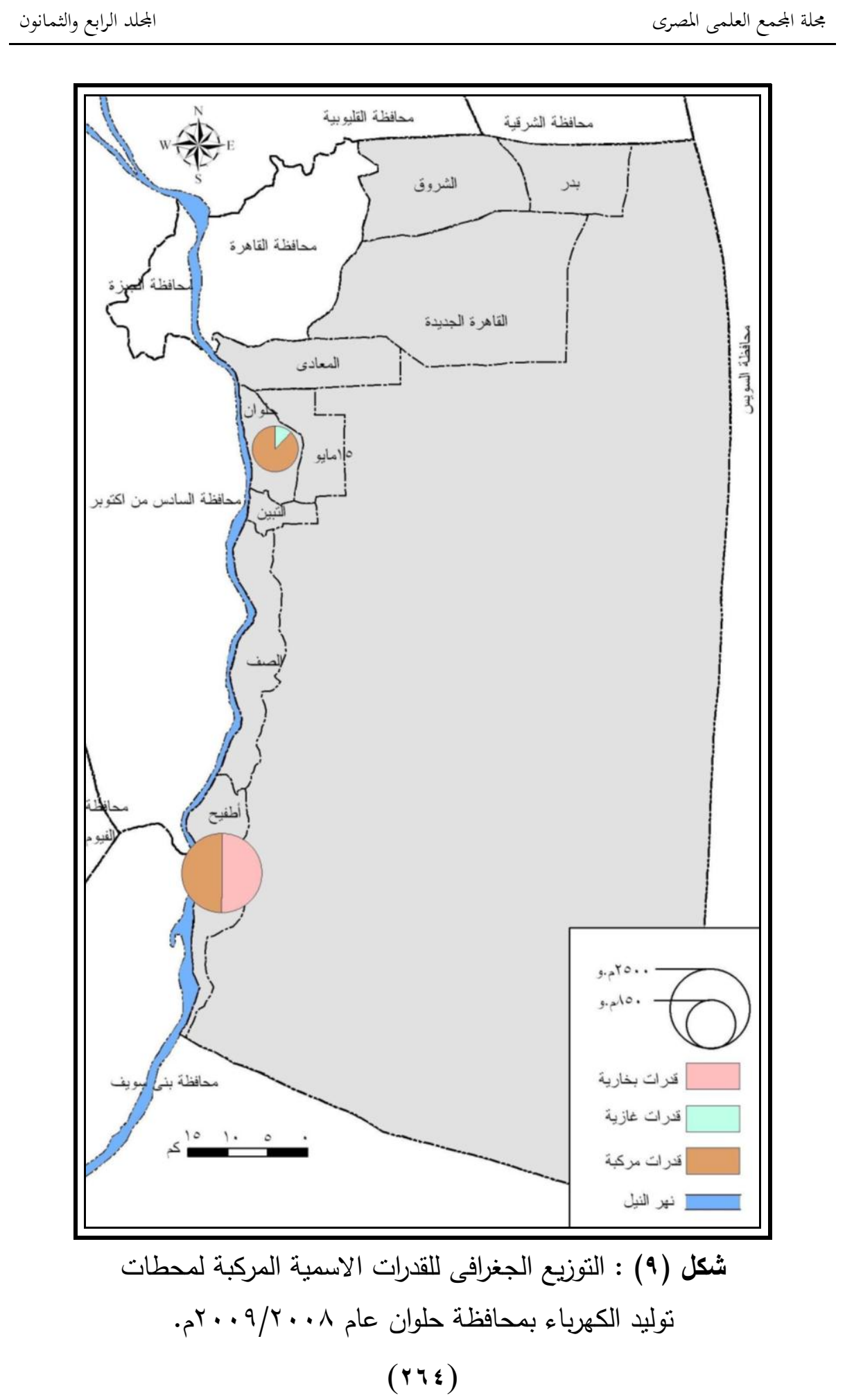


جدول (r) : الحمل الاقصى الثهرى لمحطات توليد الكهرباء

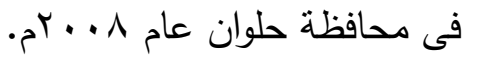

\begin{tabular}{|c|c|c|c|c|c|c|}
\hline \multicolumn{6}{|c|}{ الحمل الاقصى ( بالميجاوات ) } & \multirow{3}{*}{ شهور عام } \\
\hline الكريمات & الكريمات & الكريمات & محطة & جحطة & محطة & \\
\hline المركبة & (1) & 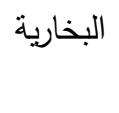 & حوف & 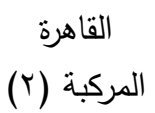 & المركبة (1) & \\
\hline- & 07. & $M \cdot r$ & 19 & 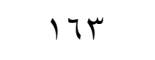 & 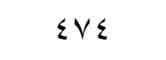 & 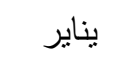 \\
\hline- & roor & I TON & $\vee q$ & r & $\varepsilon 7 V$ & فبراير \\
\hline- & oro & I rAo & $v_{1}$ & 107 & $\varepsilon 79$ & 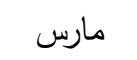 \\
\hline- & oro & $1 Y 17$ & vo & 101 & $\leqslant 7 V$ & 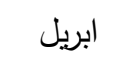 \\
\hline- & $01 \mathrm{~V}$ & ITVV & vo & 107 & $\varepsilon \neg \varepsilon$ & 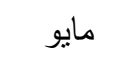 \\
\hline- & $0 . \varepsilon$ & Ir.. & V. & $1 \leqslant \Lambda$ & $\varepsilon \wedge 9$ & يونيو \\
\hline- & 0.1 & I TAK & $V Y$ & $1 \leq 7$ & $\varepsilon \vee \wedge$ & يوليو \\
\hline- & $V \leq r$ & IYTE & Vr & $1 \leq 0$ & ETr & | اغسطس \\
\hline- & vol & ITVV & VT & $1 \leqslant 0$ & $\varepsilon r$ & سبتمبر \\
\hline- & VฯA & $I T \leqslant V$ & vo & 100 & sor & 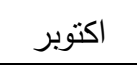 \\
\hline- & VYO & $\mid$ & vo & $10 \mathrm{~V}$ & $\varepsilon \uparrow$. & 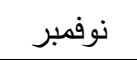 \\
\hline- & אדם & |דוצ| & $V Y$ & זדו & $\sum \pi r$ & ديسمبر \\
\hline
\end{tabular}

المصدر: وزارة الكهرباء والطاقة، الثركة المصرية لنقل الكهرباء، قطاعات التثغيل، التقارير الثهرية للتثغيل عام ^ ... أم، صفحات متفرقة.

- - تعد محطـة توليد كهربـاء الكريمـات البخاريـة أكبر المحطـات بمنطقة الدراسـة وصولا إلى الحمل الأقصى حيث بلغ أعلى قيمة لله ب. با ميجاوات فى شهر يناير 1 . . بام، بينما سجلت محطة توليد كهرباء وادى حوف أدنى حمل أقصى فى منطقة الدراسة فى شهر يونيو 1 . . rم، وهو • V ميجاوات. 
- ومن شكل (• (1) يتبين أن هناك ارتباط بين محطات توليد الكهرباء بمدينة حلوان،

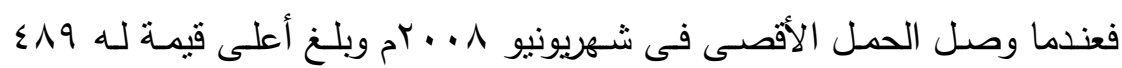
ميجاوات فى محطة جنوب القاهرة المركبة (1) (منشأة ناصر)، وسجل فى الثـر نفسـه أدنى قيمة لله فى محطة وادى حوف حيث وصل إلى · V ميجاوات، وهذا يبين التكامل بين محطات منطقة الدراسة، فعندما يتم التحميل الأقصى فى محطة

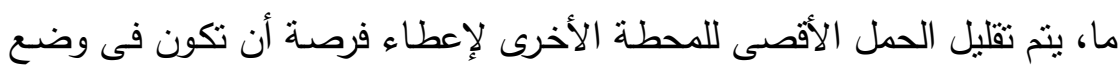
احتياطى التشغيل ولصيانة المعدات من الإهلاك.

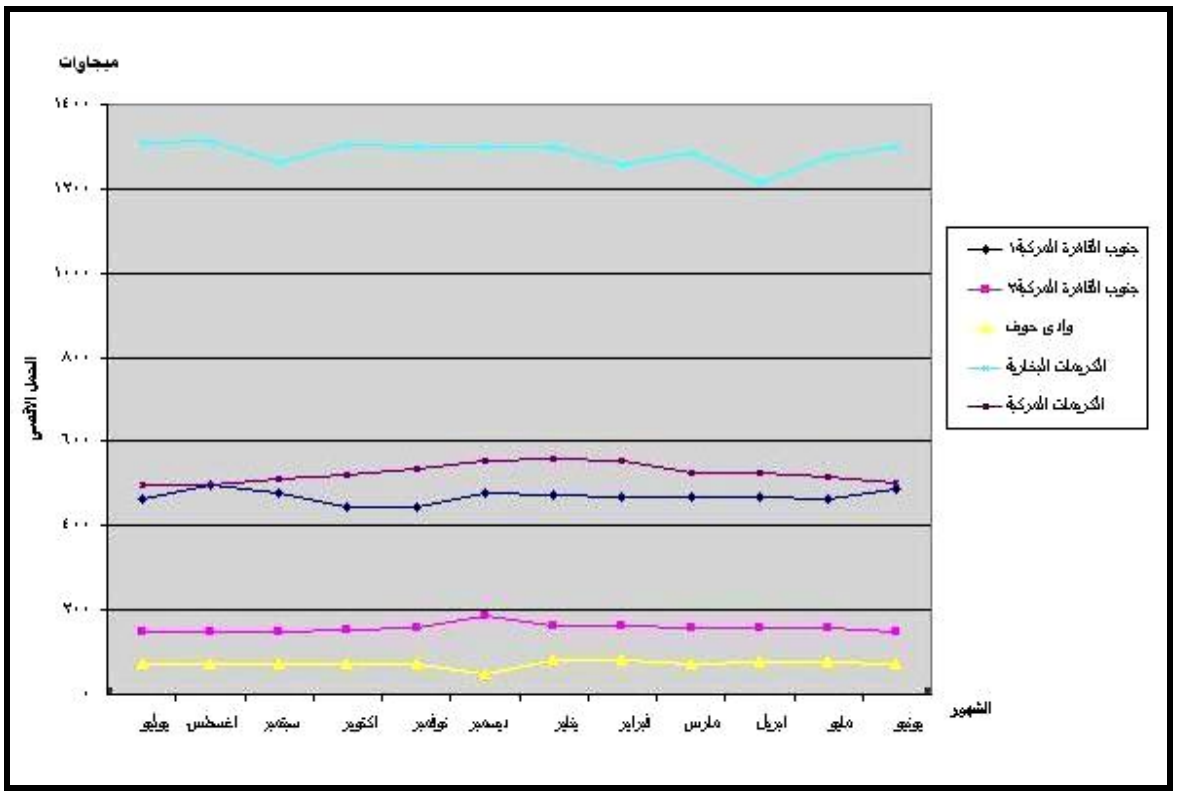

شكل ( • 1) : الحمل الأقصى الشهرى لمحطات نوليد الكهرباء

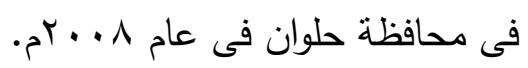

- - نلاحظ أيضـا أن أعلى قيمة للحمل الأقصى سجلت فى معظم محطات توليد الكهربـاء فى شـهور الثـتاء: ديسمبر ، وينـاير ، وفبراير ، ففى شـهر يناير بلغت 
ثـلاث محطـات هـى: الكريمـات البخاريـة، وجنـوب القـاهرة المركبـة (ب)، ووادى

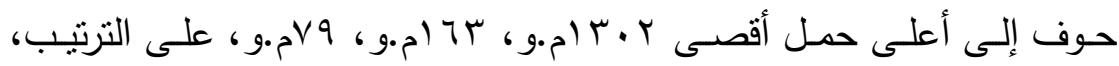

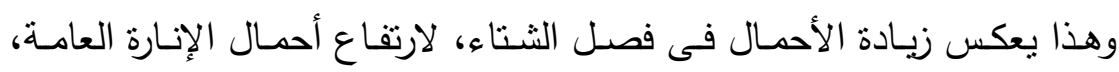
بسبب قصر ساعات النهار وطول فترة الليل، والحاجة إلى استخدام الكهرباء فى التذفئة والإنارة معا. - بينما ظهر أن أدنى حمل أقصى سجل فى معظم محطات توليد الكهرباء كان فى شهور الصيف: يونيو، ويوليو ، وأغسطس. ففى شهر يونيو بلغ أدنى حمل

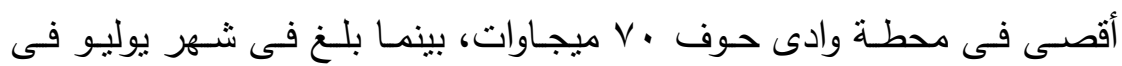

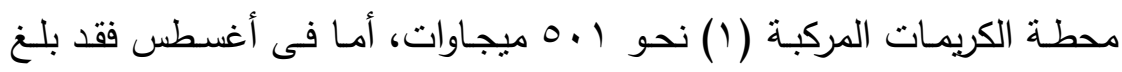
أدنى حمل أقصى فى محطة جنوب القاهرة المركبة (Y) هـ (ميجاوات، وهذا

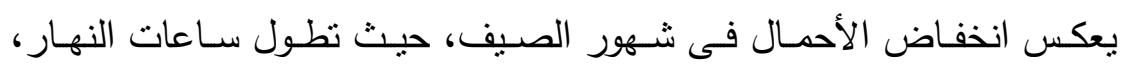
وقصر فترة الليل، مما يتبعه انخفاض فى أحمال الإنارة العامة.

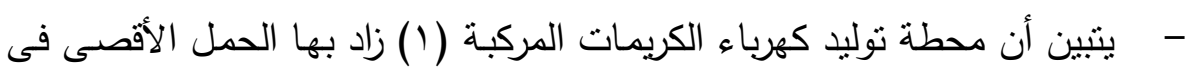

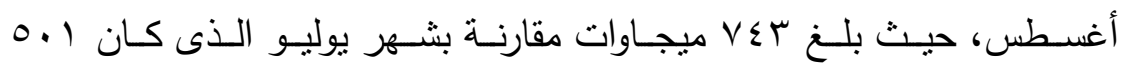

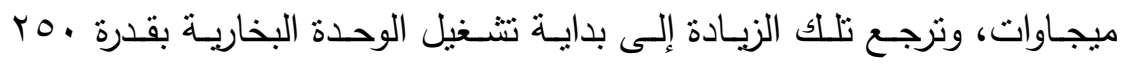
ميجاوات.

ثالثاً : الطاقة الكهربائية المولدة :

تعتمد الكهربـاء المنتجـة مـن محطـات التوليد على قدرتها الاسـية، كمـا تمثل انعكاسا مباشرا لحجم الطلب على الكهرباء، والذى يؤثر بدوره على الأحمال المطلوبة

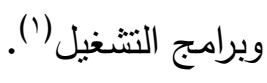
(1) ياسر إبراهيم محمد الجمال، الطاقة الكهربائية في محافظة دمياط- دراسة فن الجغرافية الاقتصادية، رسالة

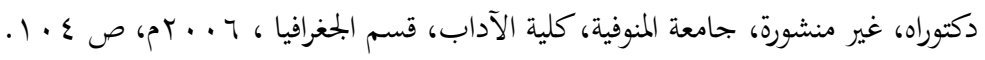


ومنذ أن طبق المخترع تومساس إديسون فكرة التوليد الثتائى (') عام rA ام فى

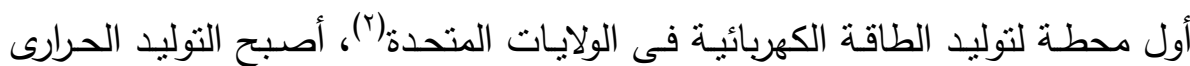

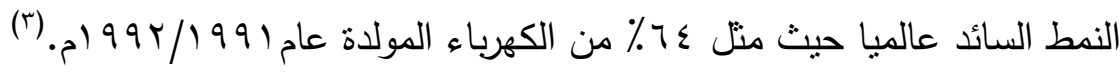

ويعتمد التوليد الكهربائى بمنطقة الدراسـة على التوليد الحرارى، ويوجد بها ثلاثة أنواع من محطات التوليد: غازية (وادى حوف)، وبخارية (الكريمات البخارية)، والدورة المركبة [محطات جنوب القاهرة المركبة ( ())، (Y)، والكريمـات المركبـة (l)، (r)]؛ ومن هنا يتبين أن منطقة الدراسـة بها محطة واحدة للتوليد الغـازى، ومحطـة واحدة للتوليد البخارى، وأربع محطات دورة مركبة.وتنتخدم المحطة الغازية فى تغطية أحمال

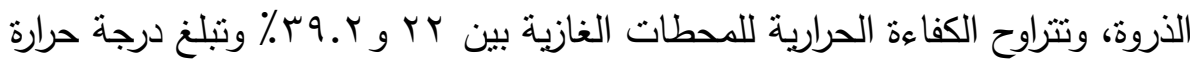

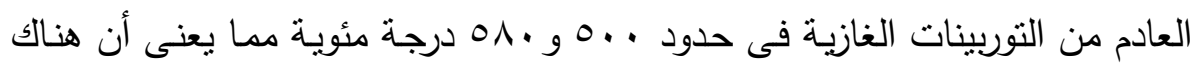
طاقة حرارية مفقودة؛ وحتى يمكن المحافظة على هذه الطاقة الحرارية من الضياع فقد

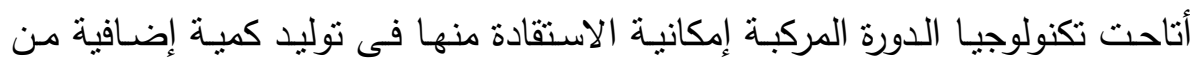
الطاقة الكهربائية بدون استخدام وقود إضافى وذللك من خلال استخدام غلاية لاستعادة

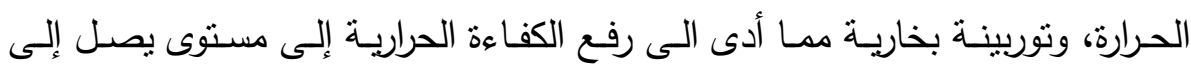

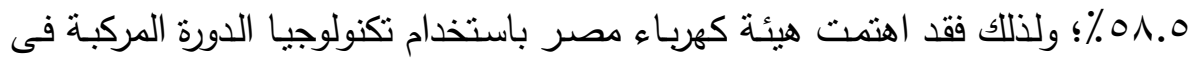

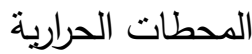
(1) يتكون نظام التوليد الثنائى من محرك، ووحدة توليد تعمل بالوقود لإنتاج الكهرباء، ووحدة استعادة

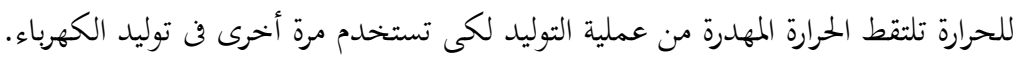

(2) Schaffer, J. \& Others, "Clean Energy Solutions", United States, July 2006, p. 18.

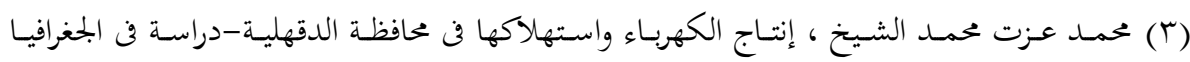

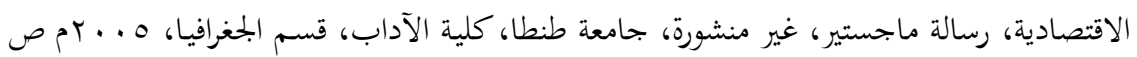


المقامة(')؛ ولهذا نجد وجود أربع محطات حرارية فى منطقة الدراسة نستخدم تكنولوجيا الدورة المركبة، تمثل نسبة 7.77\% من محطات منطقة الدراسة (شكل (1).

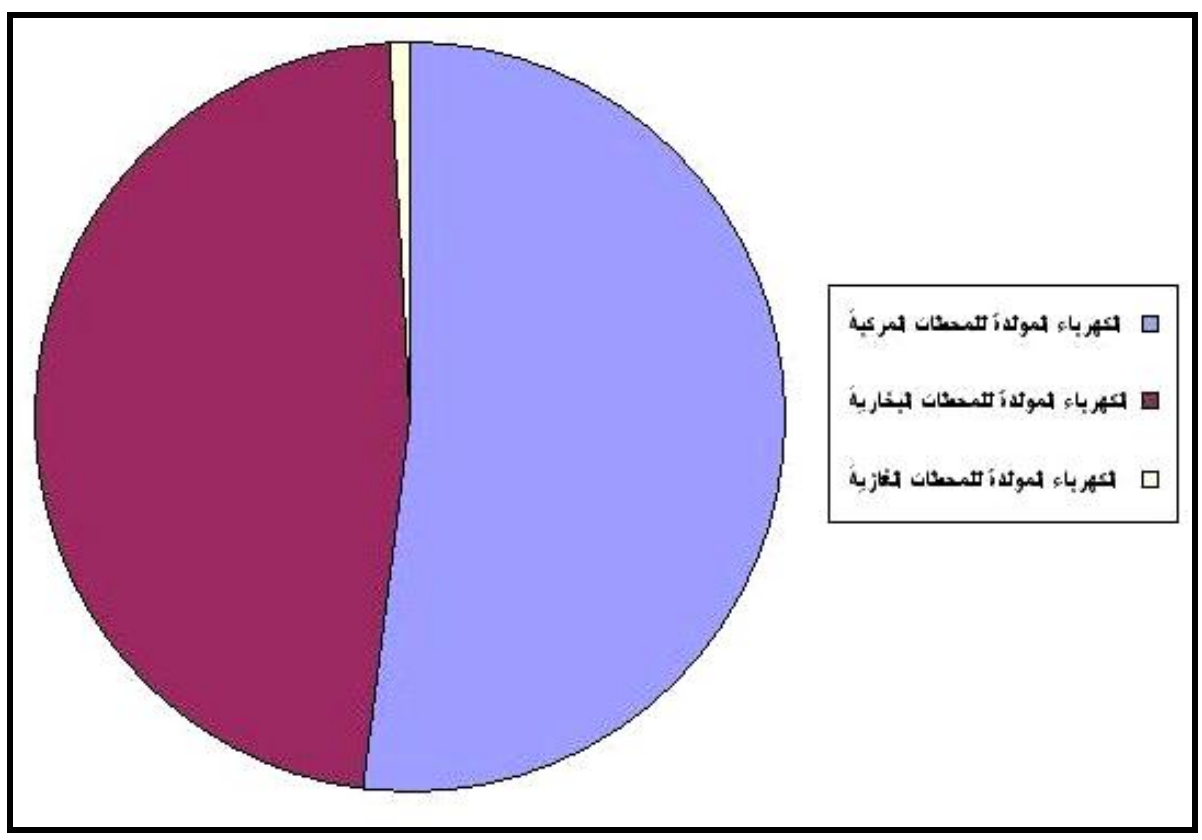

$$
\begin{aligned}
& \text { شكل (11) : الكهرباء المولدة بمحطات التوليد فى }
\end{aligned}
$$

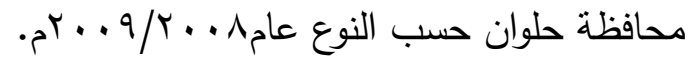

(1) محمد محمد عوض، خبرة الشركة القابضة لكهرباء مصر في استخدام الوحدات الغازية ووحدات

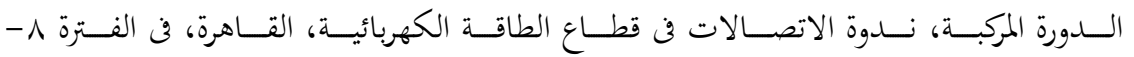

$$
\text { . . . T/11/9 }
$$




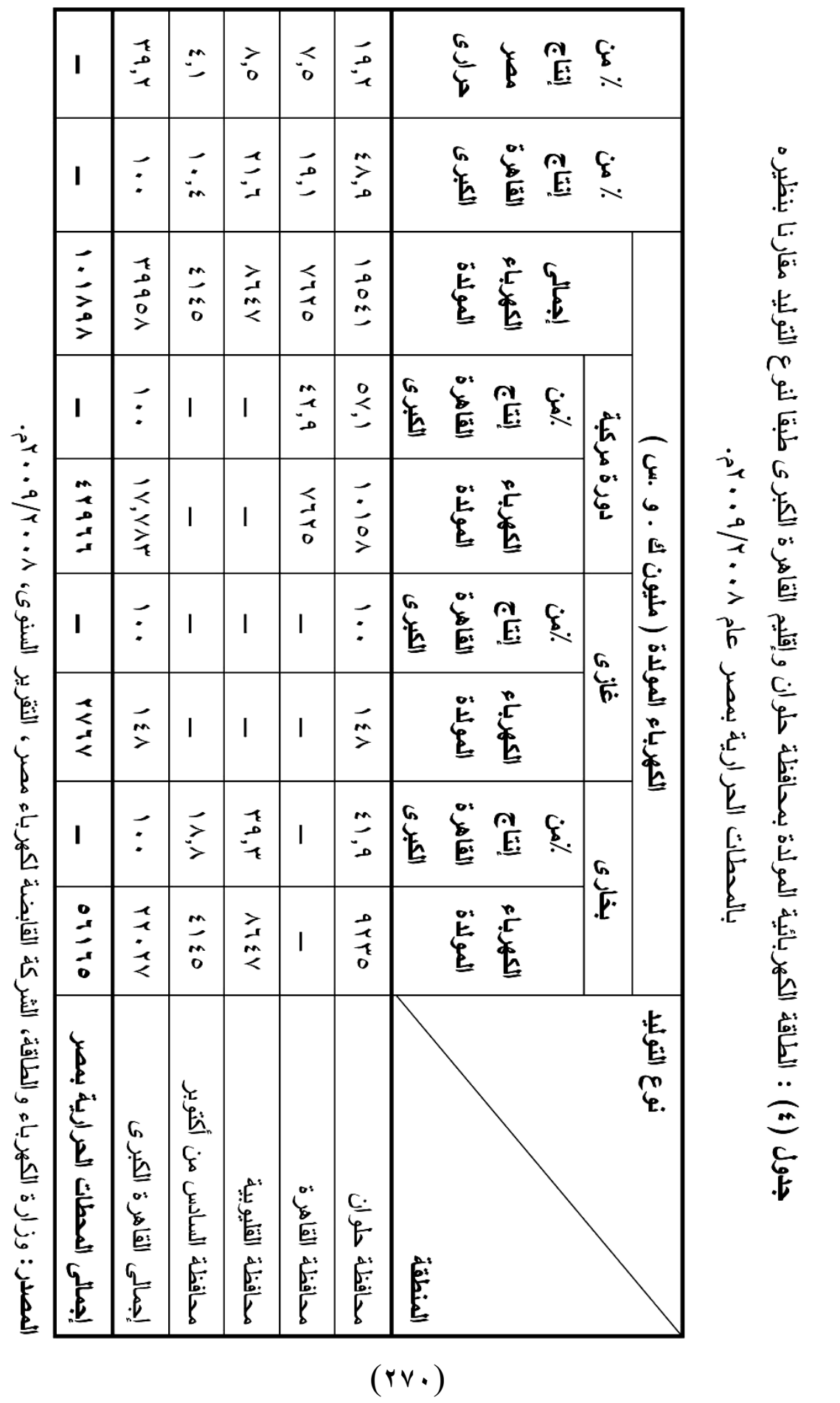




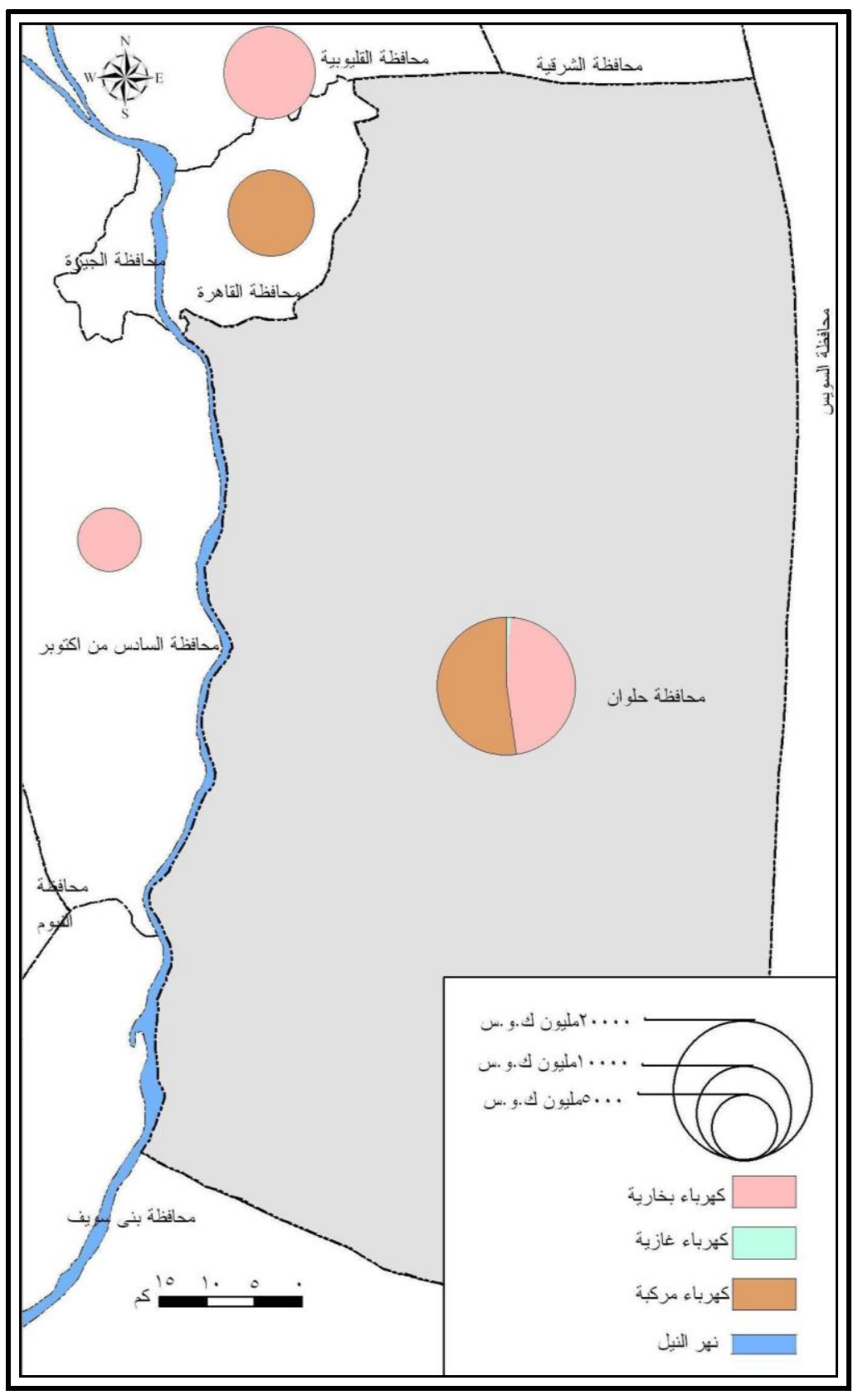

شكل (r I) : التوزيع الجغرافى للطاقة الكهربائية المولدة

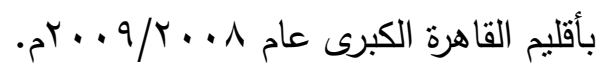

$(r \vee 1)$ 


$$
\text { ومن دراسة الجدول (ع) وتتبع الثكل (r ا ) يتضح ما يلى: }
$$

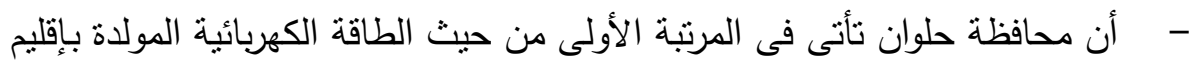

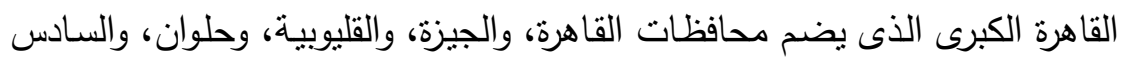

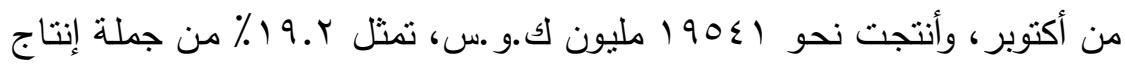

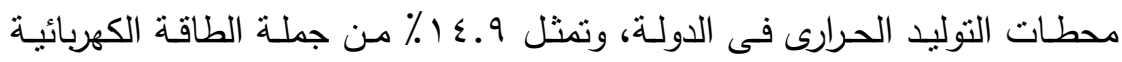

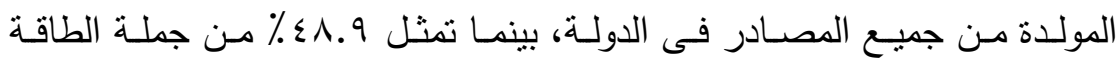
الكهربائية المولدة فى إقليم القاهرة الكبرى. تسـاهم محطة الكريمات البخارية بنسبة 9 ـ اء ٪ من إجمالى التوليد البخارى فى إقليم

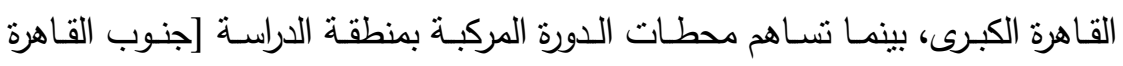

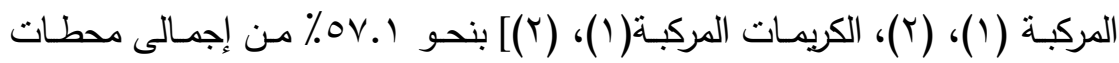

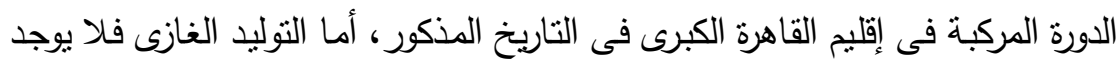
بإقليم القاهرة الكبرى سوى محطة وادى حوف التى تقع بمنطقة الدراسة وتساهم بنسبة

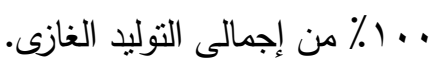

$$
\text { يتبين من الجدول (0) والثكل (r ا ) ينتين ما يلى: }
$$

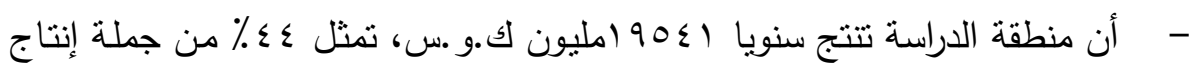
الكهربـاء بإقليم القاهرة الكبرى؛ ويتوزع هذا الإنتاج على محطات التوليد بنديا بمنطقة

$$
\text { الدراسة: البخارية، والمركبة، والغازية. }
$$

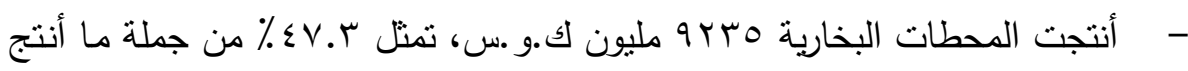
بمحافظة حلوان؛ ويتركز هذا الإنتاج على محطة الكريمات البخارية الوحيدة بمنطقة

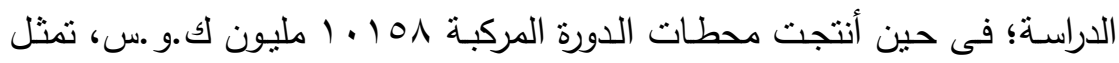

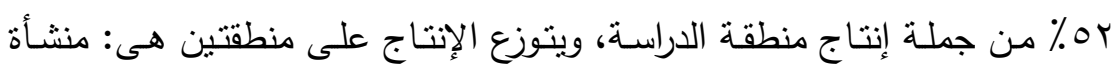

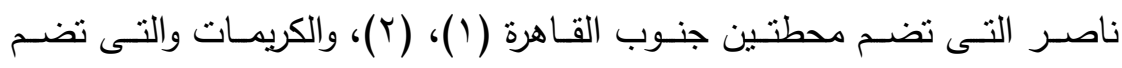

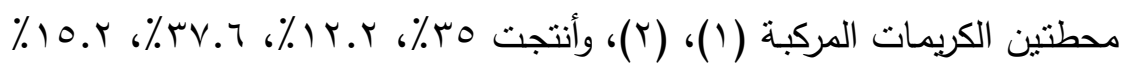

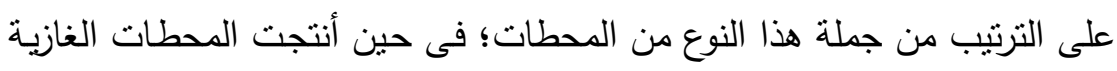

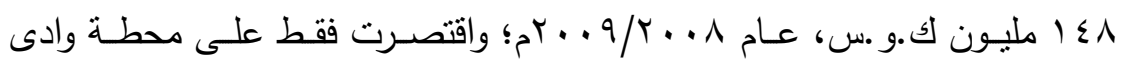




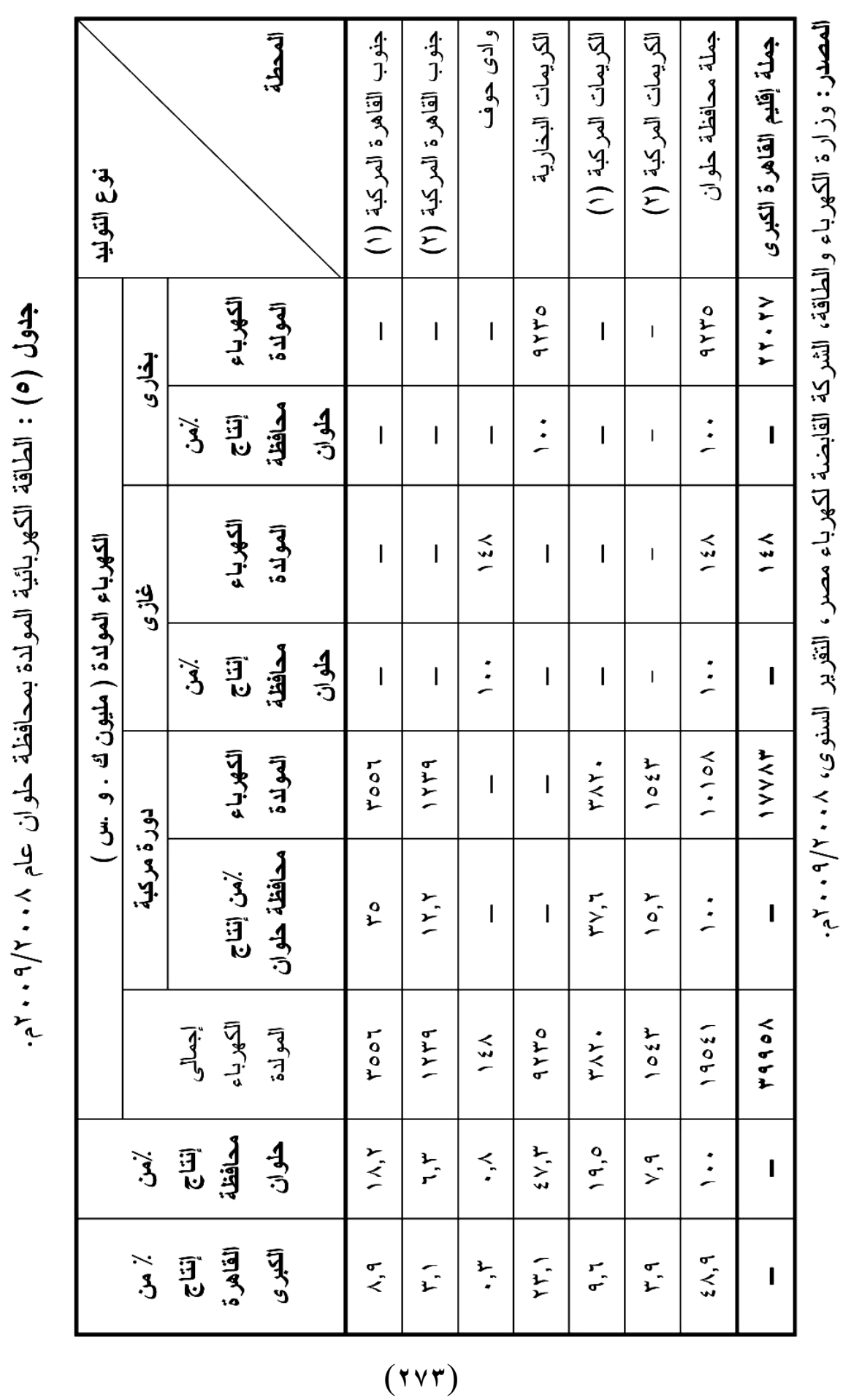




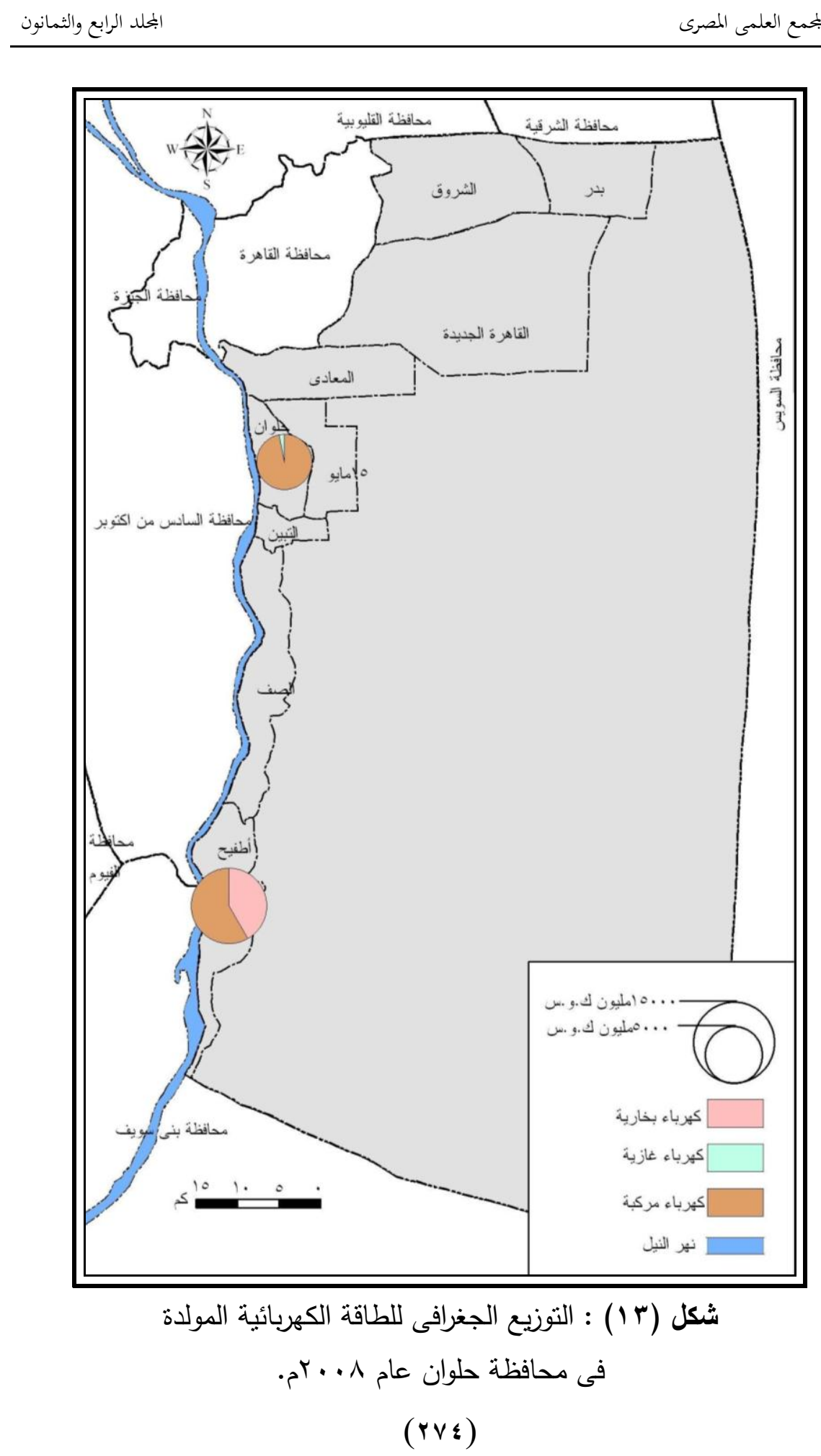


- - يتبين من شكل (ع () أن إنتاج محطة توليد الكريمات البخارية يمثل نحو ما يقرب

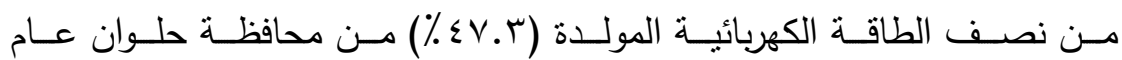

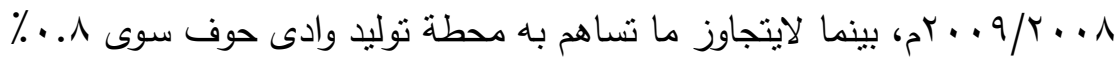

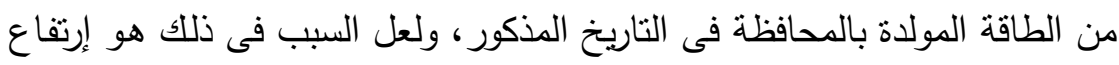
تكلفة الوقود الغازى مقارنة بالتوليد البخارى، بالإضـافة إلى قدم إنثـاء محطة وادى حوف مقارنة بالثانية ذات المنشآت الحديثة.

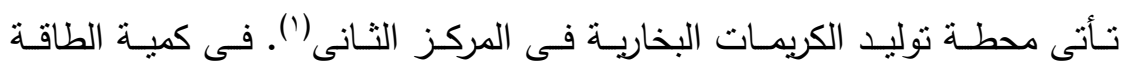

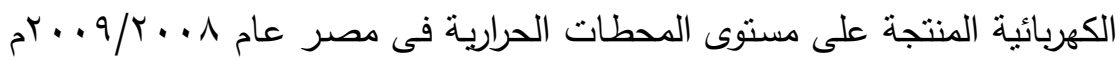

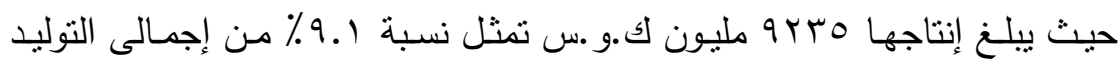

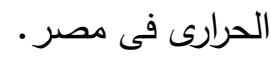

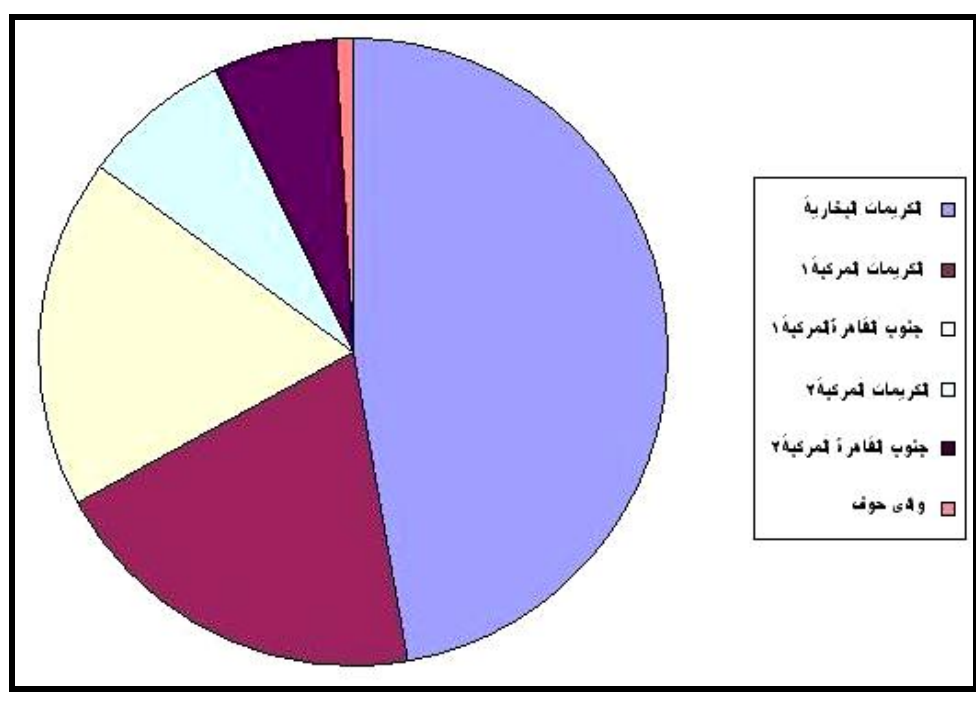

شكل (ع 1) : الكهرباء المولدة بمحطات التوليد

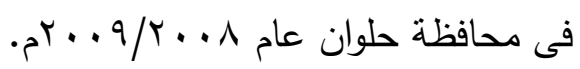

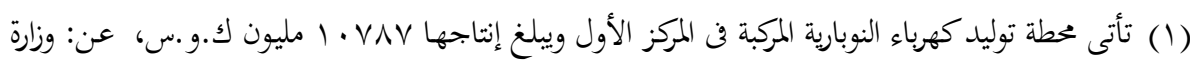

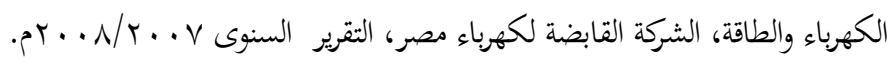




$$
\text { رابعاً : موسمية إنتاج الكهرباء : }
$$

يتقاوت إنتاج الكهرباء فى محطات التوليد على مدى شهور العـام وذلك وفقا لتغير أحمال التشغيل، وتغير حجم الطلب على الكهربـاء من وقت لآخر ؛ وتجدر الإثـارة إلى أن لكل محطة توليد طاقة إنتاج قصوى، فقد يختلف إنتاج المحطة بين عام وآخر ، أو خلال أثهر السنة، وحتى خلال ساعات اليوم، إلا أن محطة التوليد لا لا لتهل يمكن أن تتجاوز طاقتها القصوى(')

ويوضح الجدول رقم (ج) الإنتاج الثهرى من الكهرباء المولدة ومعامل الحمل(؟)

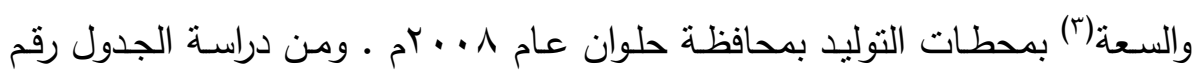

$$
\text { والثكل رقم (0 1) يتضح ما يلى: }
$$

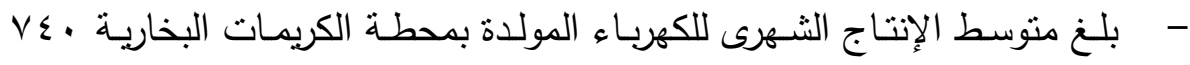

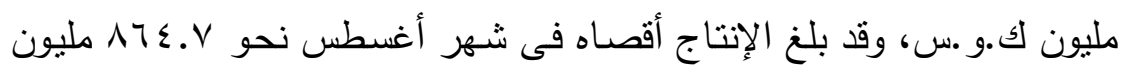

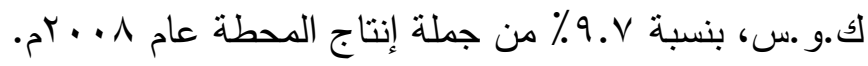

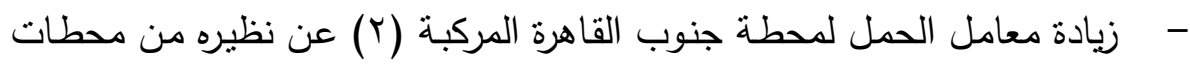

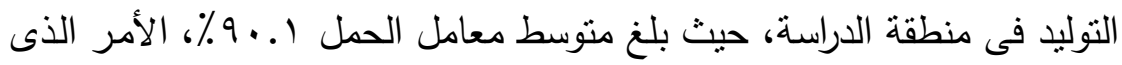
يبرز دور محطة جنوب القاهرة المركبة (Y) كمحطة مركزية فى تغطية أحمال

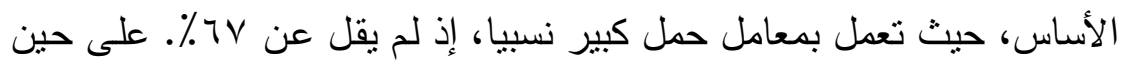

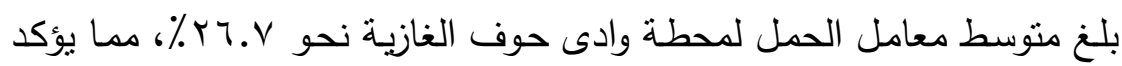
أن هذه المحطة تعمل فقط وقت الحاجة إليها لتغطية أحمال الذروة، حيث يشتد

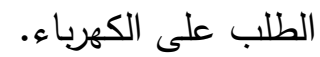

(1) فاتح شعبان شعبان، جغرافية الطاقة الكهربائية فن سوريا،رسالة ماجستير، غير منشورة، جامعة عين

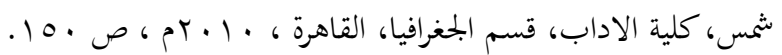

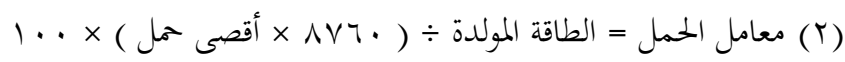




$$
\text { (广⿳) معامل السعة = الحمل المتوسط ؟ القدرة الاسمية × . 1. }
$$




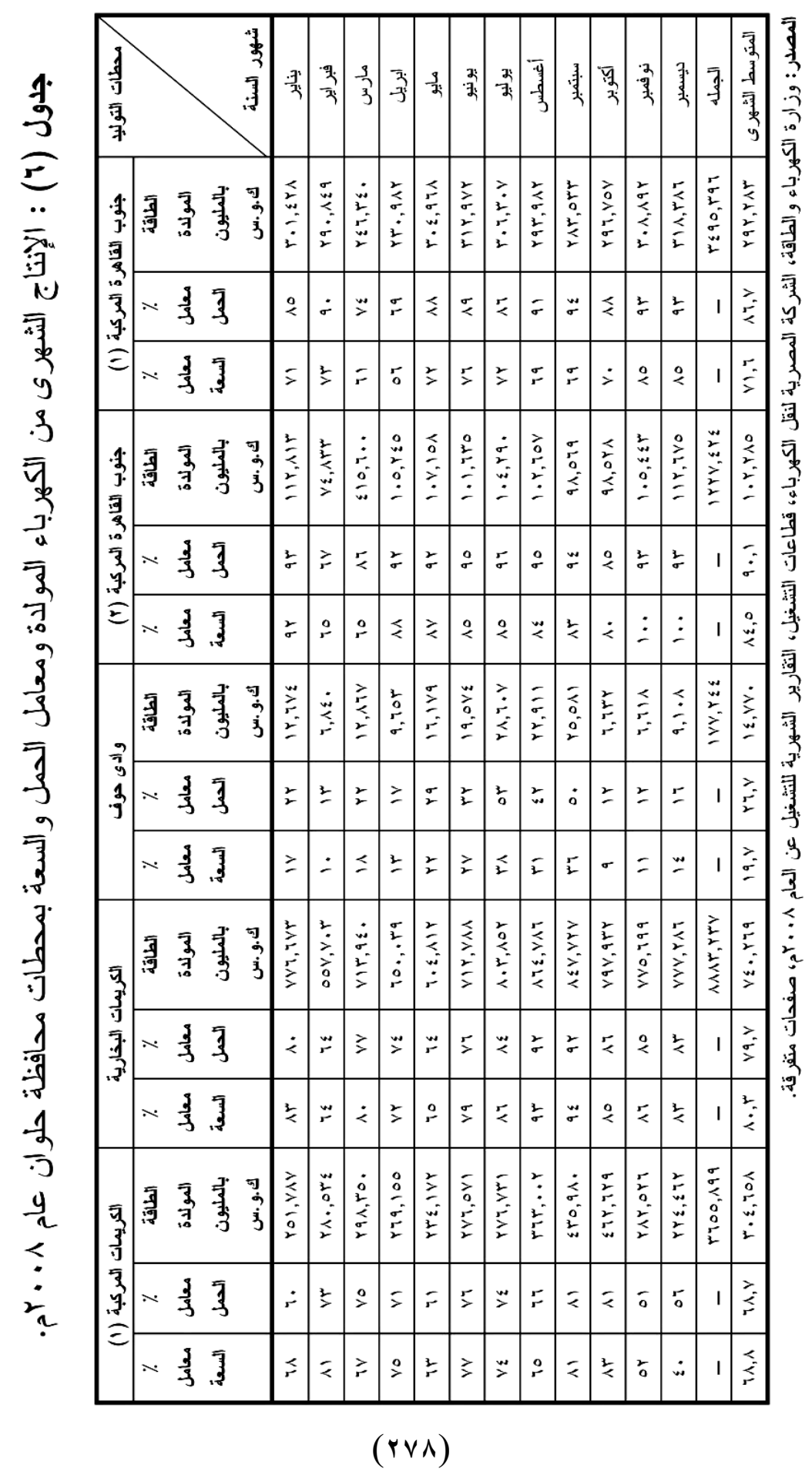




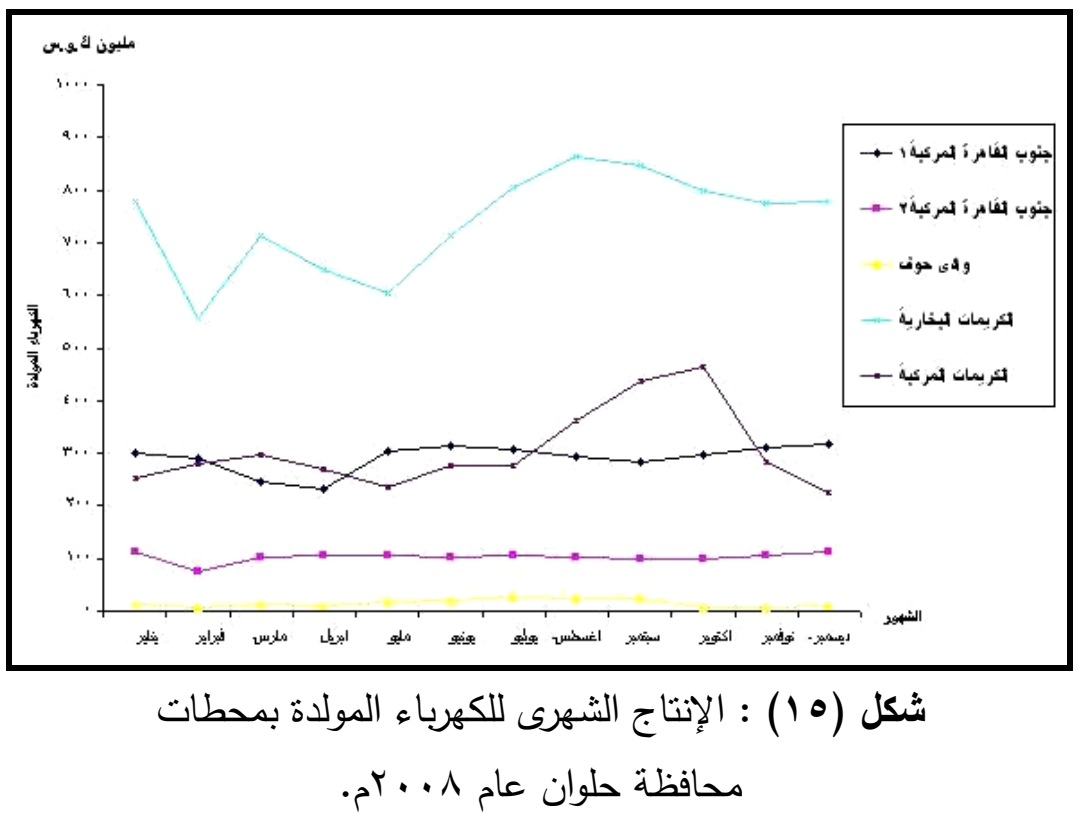

- ل العمل محطات التوليد بكامل حمولتها لأن ذلك يجهد المحطة ويؤدى إلى

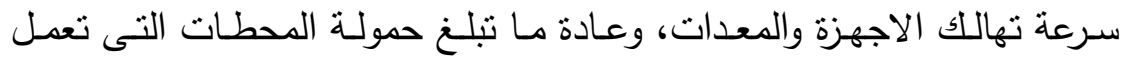

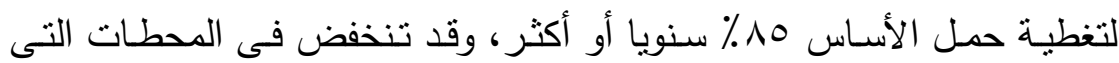
تعمل لتغطية حمل الذروة إلى أقل من • ٪ سنويا (').

$$
\text { ويتبين من الجدول (7) والثكل (7 ا () ما يلى : }
$$

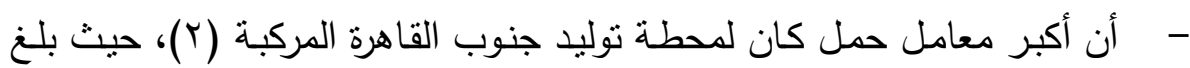

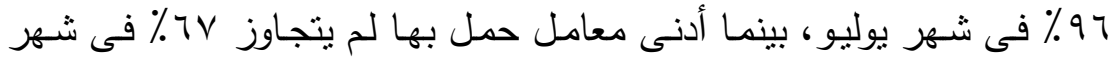

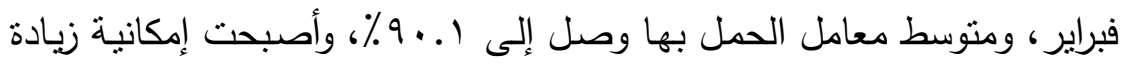

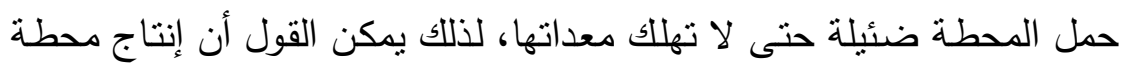
جنوب القاهرة المركبة (Y) قد بلغ ذروته، وذلك للاستقادة من مزايا تكلفة الإنتاج المنخفض، والكفاءة العالية لمحطات الدورة المركبة.

(1) Chapman, J.D.: "Geography and Energy Commercial Energy Systems and National Policies". United States, New York, 1989, P. 102. 


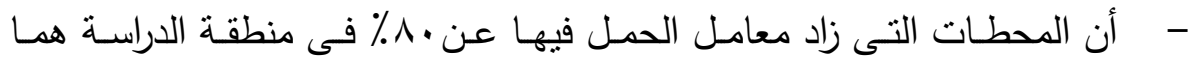

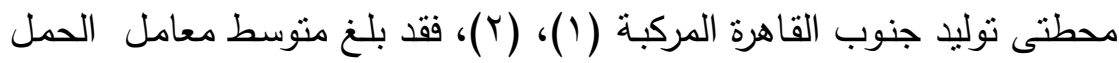

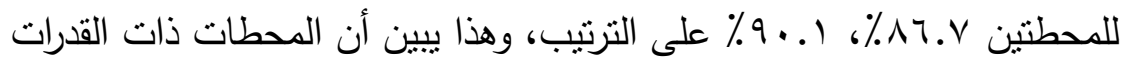

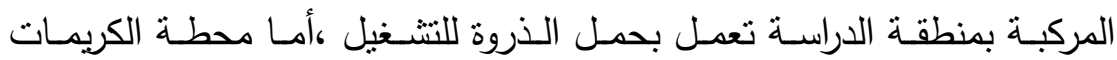

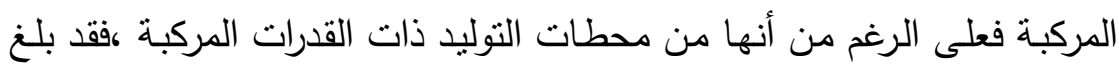

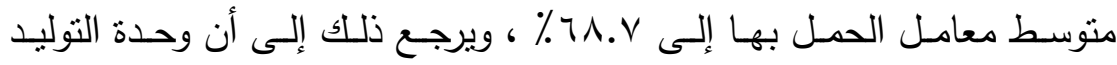
البخارية بالمحطة لم يتم تتغيلها حتى يونيو م م. . بام.

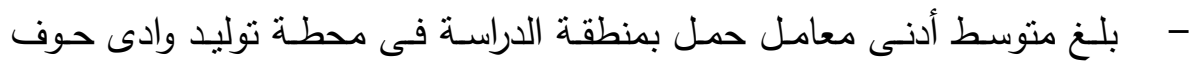

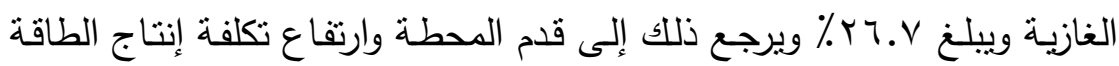
الكهربائية فى المحطات الغازية.

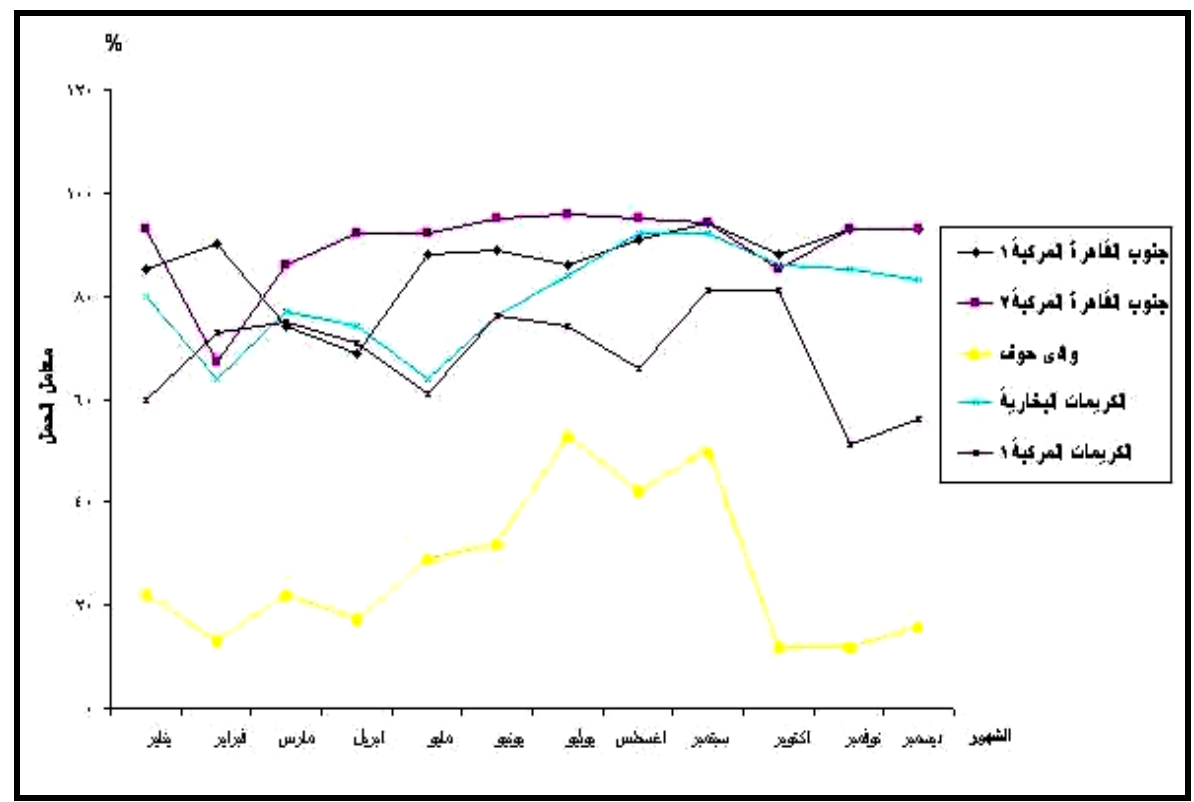

شكل (1 1 ) : معامل الحمل الثهرى لمحطات التوليد الكهربى

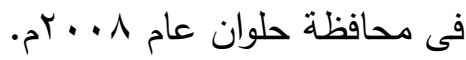

$(\nvdash \wedge \cdot)$ 


$$
\text { خامساً : معدلات استهلاك الوقود والكفاءة الحرارية وتكاليف الإنتاج : }
$$

يعتمـد التوليد الحـرارى على ثلاثة أنـواع مـن الوقود: السـولار ، والمـازوت، والغـاز الطبيعى؛ وتتجه الدول حاليا للتوسع فى استخدام الغاز الطبيعى فى تشغيل محطات نوليد

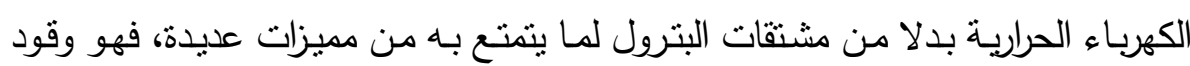
نظيف لا يحتوى على شوائب أو كبريت، وينتج عن احتراقه كميات أقل من الملوثات أهمها: أكاسيد النيتروجين، وغاز ثانى أكسيد الكربون مقارنة مع أنواع الوقود الأخرى، وهو ذو كفاءة عالية، بالإضافة إلى أن المعدات المستخدمة فى تشغيله أقل تكلفة من المعدات

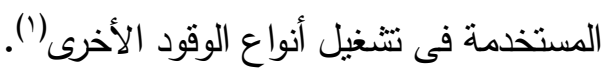

\section{(أ) معدلات استههلاك الوقود :}

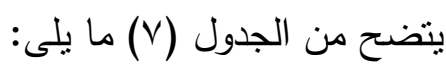

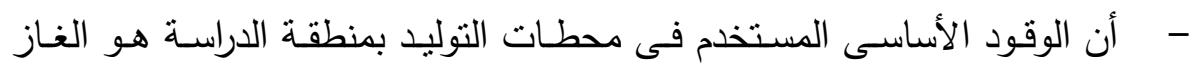

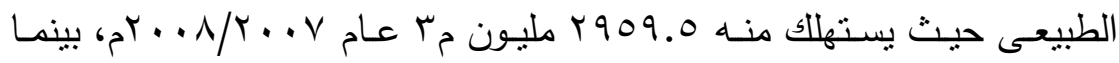
استهالاك المحطات من المازوت فيبلغ ^. . ـ ـ 1 ألف طن، أما استهلاك السولار فيكاد ينعدم استخدامه حيث استهلك منه ب ال طن طن.

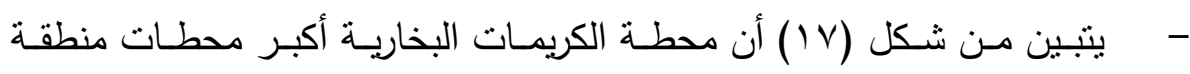

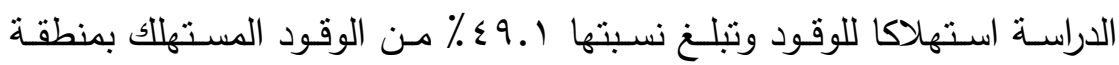

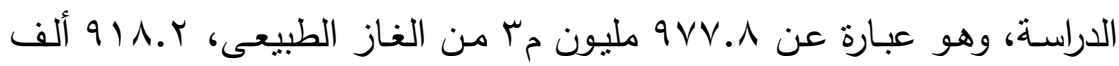

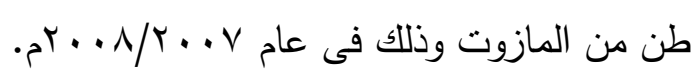

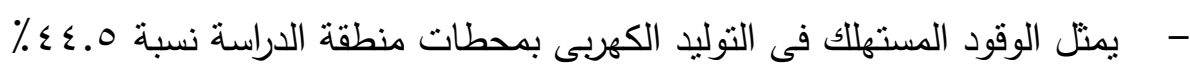

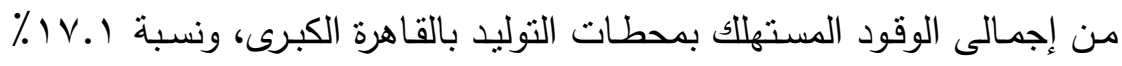
من إجمالى الوقود المستهلك فى المحطات الحرارية بمصر .

(1) Jefferson, W. Tester, \& Others: "Energy and the Environment in the $21^{\text {st }}$ Century". MIT Press, London, 1991, P. 676. 


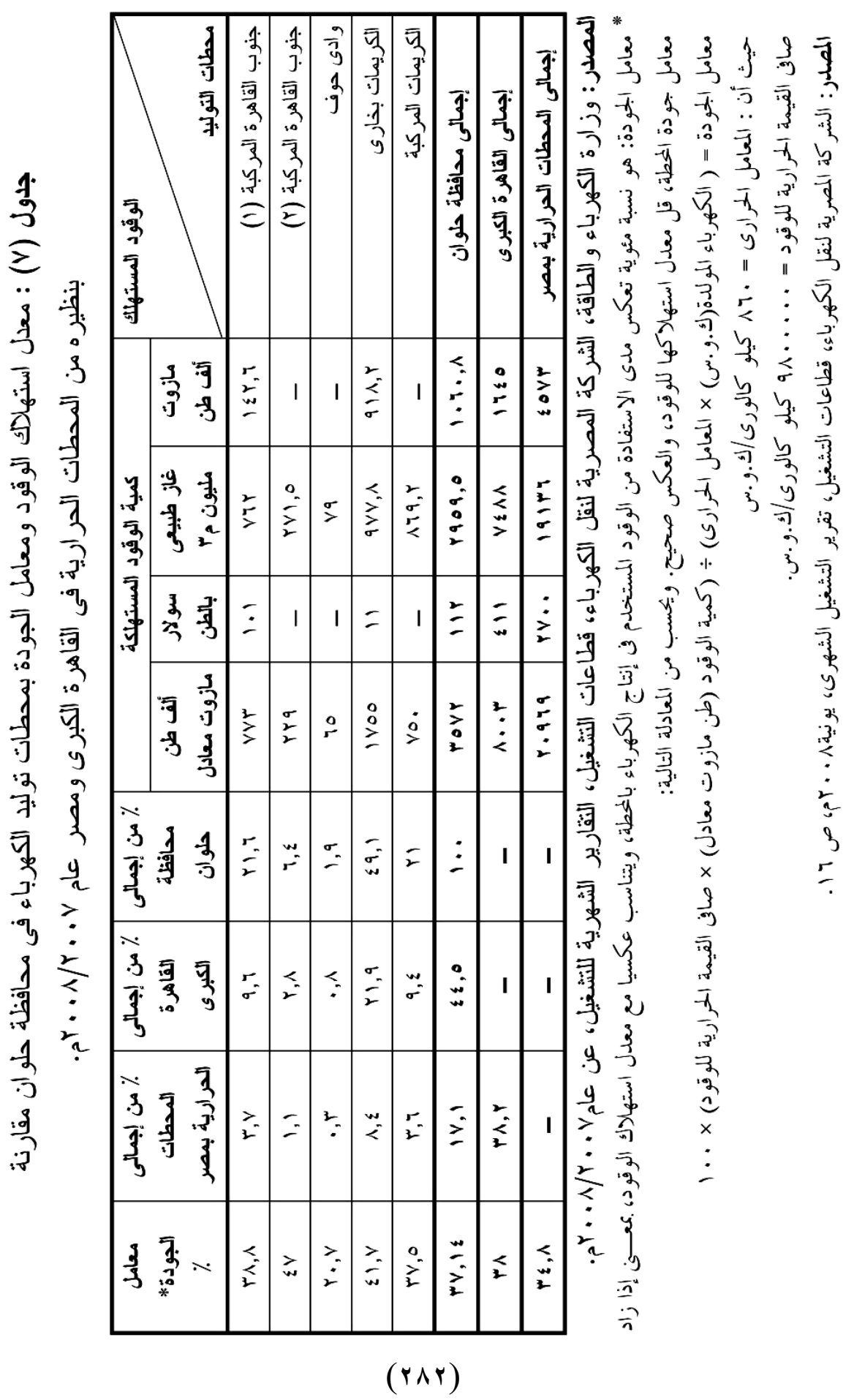




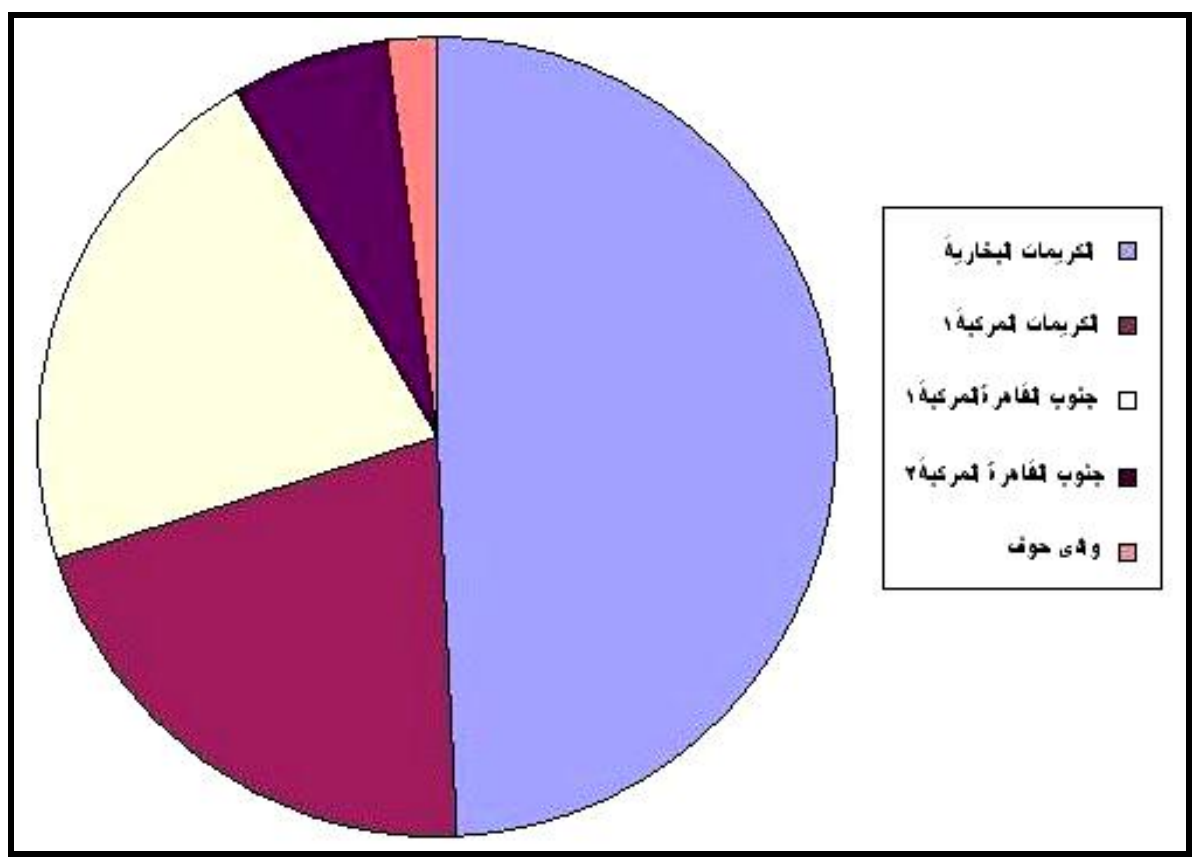

شكل (IV) : كمية الوقود المستهلكة بمحطات التوليد

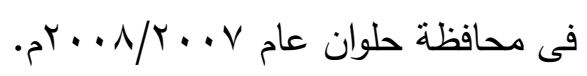

ويوجه منتجو الكهرباء الحرارية فى العالم اهتماما أساسيا إلى استهلاك الوقود،

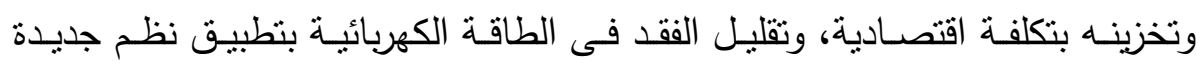

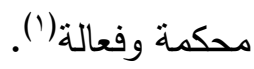

(1) فـائزة بنـت محمــ كريم، إنتـاج الطاقـة الكهربائيسة واستهلاكها في المنطقـة الغربيـة بالمملكـة العربيـة

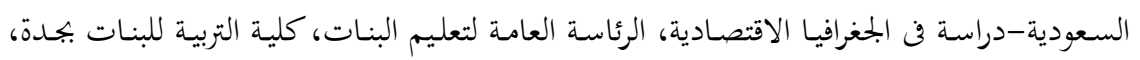

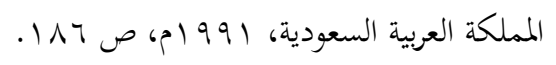




\section{(ب) الكفاعة الحرارية (معامل الجودة) :}

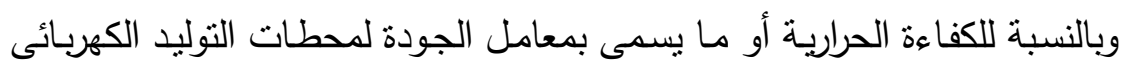

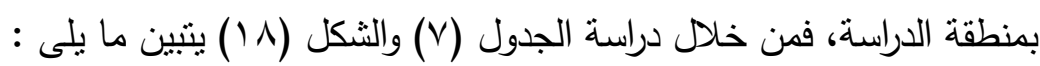

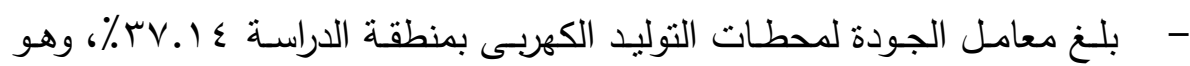

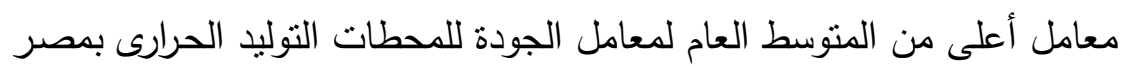
والذى يبلغ ^. ع ٪\%، وهذا يعكس كفاءة تشغيل محطات منطقة الدراسة.

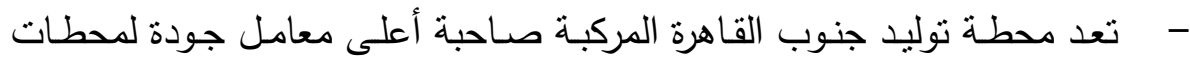

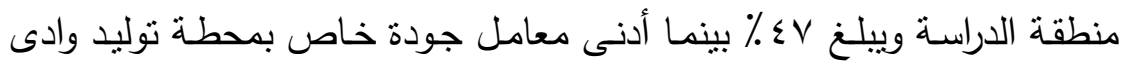
حوف ويبلغ \.. r٪ ولهذا السبب فإن هذه المحطة لا يعتمد عليها فى التوليد الكهربائى حيث تتتج المحطة ( ) من الطاقة المنتجة بمنطقة الدراسة.

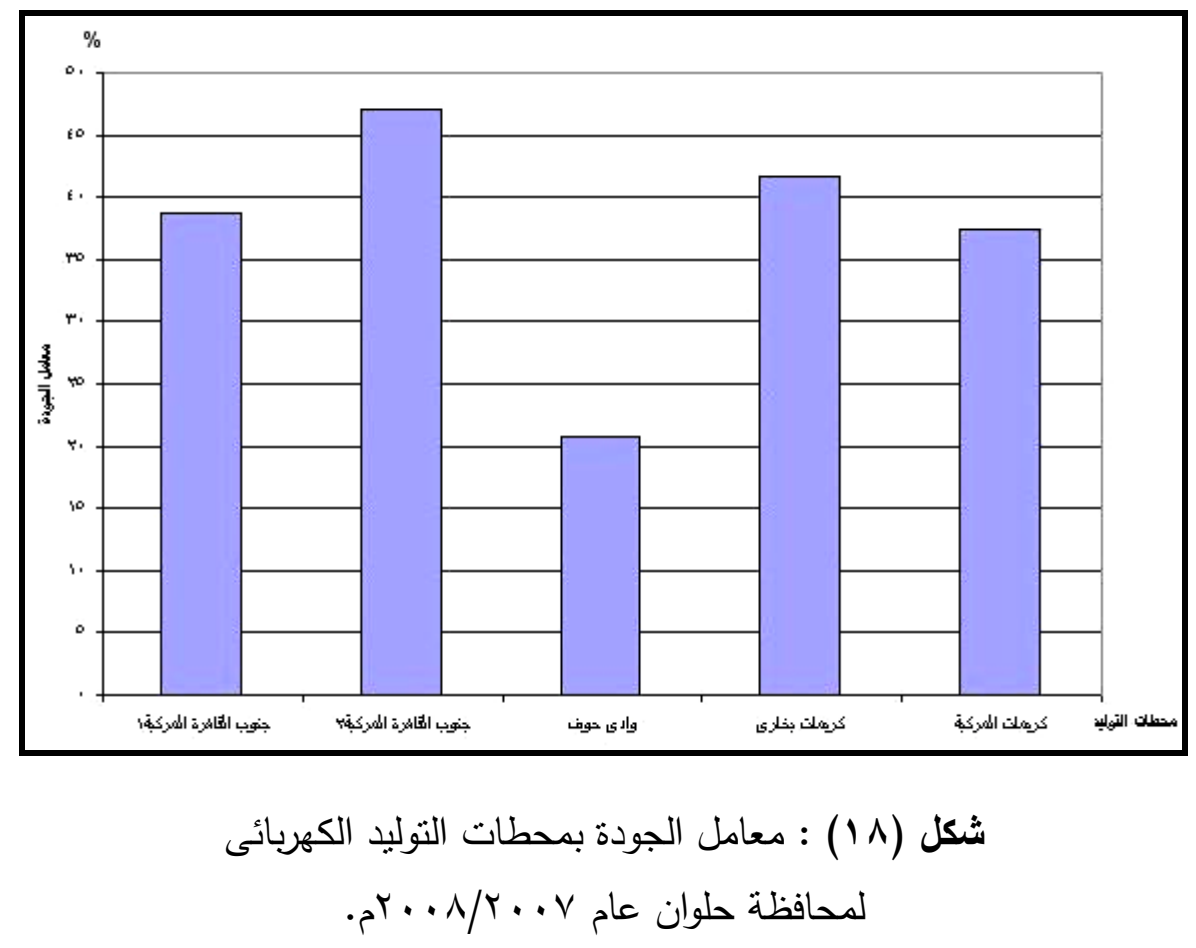




\section{(ج) تكاليف توليد ك.و.س بمنطقة الدراسة :}

جدول (^) : تكلفة توليد ك.و .س بمحطات توليد الكهرباء فى محافظة حلوان مقارنة

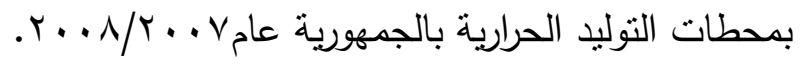

\begin{tabular}{|c|c|}
\hline (قرش/ك.و.و التوليد) & المحطة المطة \\
\hline$r . \vee \varepsilon$ & جنوب القاهرة المركبة(؟) \\
\hline$\{.17$ & الكريمات البخارية البية \\
\hline$\varepsilon . \leqslant 0$ & جنوب القاهرة المركبة( ) \\
\hline$\{.71$ & الكريمات المركبة(1) \\
\hline ^.乏) & وادى حوف الغازية \\
\hline $0 . \cdot v$ & متوسط تكلفة الوقود لمحطات محافظة حلوان \\
\hline $7 . \leqslant 7$ & متوسط تكلفة الوقود لمحطات التوليد الحرارى بالجمهورية \\
\hline$\{.17$ & منوسط نكلفة الوقود لـحطات الدورة المركبة بالجمهورية \\
\hline$\leq .9 \leq$ & متوسط تكلفة الوقود لمحطات التوليد البخارى بالجمهورية \\
\hline $1 . r$. & منوسط تكلفة الوقود لمحطات التوليد الغازية بالجمهورية \\
\hline
\end{tabular}

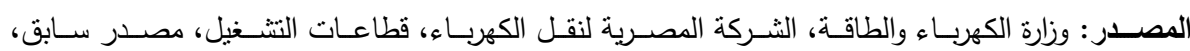

يتبين من جدول (^) الملاحظات التالية:

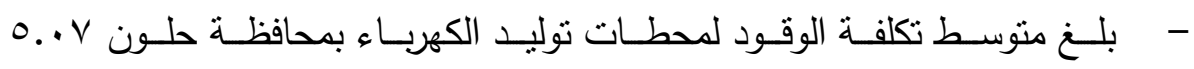

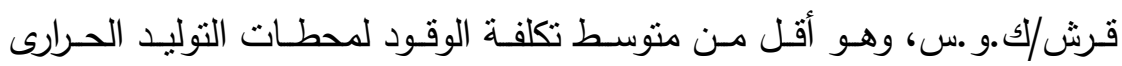
بالجمهورية والذى يصل إلى 7 ــ ـ قرش/ك.و.س، وهذا يشير إلى انخفاض تكلفة إنتاج ال ك.و .س من الكهرباء لمحطات التوليد بمحافظة حلوان، ويرجع ذلك إلى إلى أن منطقة الدراسة بها أربع محطات توليد تستخدم تكنولوجيا الدورة المركبة، وتجدر الإثارة إلى أن تكلفة إنتاج ال ك.و .س فى المحطات المركبة أقل منها فى الأنواع 
الأخرى؛ ولللك فإن الاتجاه الحديث هو تحويل المحطات إلى نظام الدورة المركبة، حيث زيادة الكهرباء المولدة دون استخدام وقود إضافى.

- - إنخفاض تكلفة إنتاج ال ك.و .س من الكهربـاء بمحطـة جنوب القاهرة المركبة

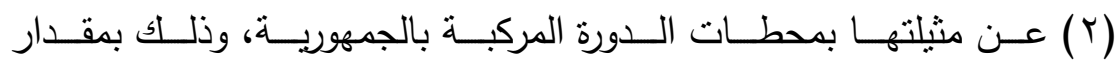

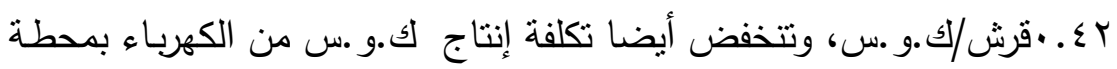
الكريمـات البخاريـة عن مثيلتها بالمحطات البخاريـة بالجمهوريـة ، وذلك بمقدار ^^. . قرش/ك.و .س، حيث تأتى فى المركز الثانى من حيث انخفاض تكلفة

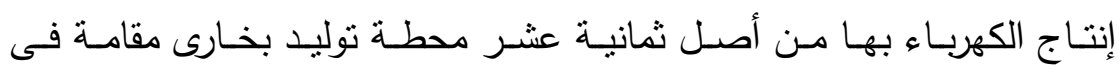
مصر (') (1) (1) - وتنخفض أيضـا تكلفة إنتاج ك.و .س من الكهرباء بمحطة وادى حوف الغازيـة

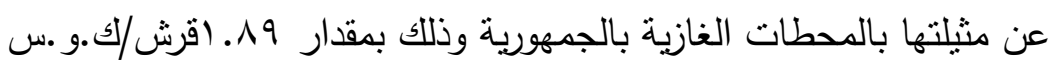

\section{الخلاصة :}

- - تعد محافظـة حلوان أكبر المحافظـات المصرية إنتاجـا للطاقـة الكهربائية بنسبة 1 ـ ا ٪ مـن إجمـالى التوليد الكهربـائى بمصـر بكافـة أثنكاله (حـرارى، مـائى، رياح، قطاع خاص). - يوجد بمنطقة الدراسة أكبر عدد من محطات توليد الكهرباء بمصر (ست محطات) من إجمالى اثثين وأربعون محطة توليد مقامه فى مصر ، وبعد استكمال المحطات الجارى إنشائها بمنطقة الدراسة سيرتفع العدد إلى تسع محطات. (1) تأتى محطة سيدى كرير في المركز الأول وييلغ تكلفة التوليد هما ـ ا.ـقرش/ك.و.س . ماكس

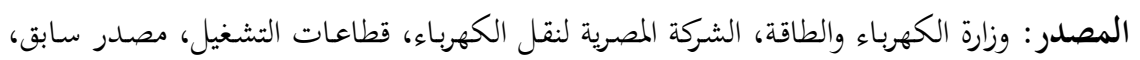
. $r \cdots N / r \cdots v$ 
- - تشهر منطقة الدراسـة إنشاء العديد من محطات الكهرباء الحرارية وهى: محطة الكريمـات المركبـة (ب)، وتجديـد محطـة التبـين لتعمـل بنظــام الـدورة المركبـة، ومحطة نوليد جنوب حلوان فى أقصى جنوب المحافظة فى قرية دير الميمون.

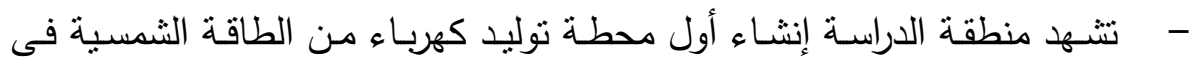
مصر بمنطقة الكريمات. - - أصبحت منطقة الكريمات بمركز أطفيح أكبر قطب فى مصر فى إنتاج الطاقة الكهربائية حيث يوجد بها ثلاث محطات توليد حراريـة، ومحطة توليد شمسية،

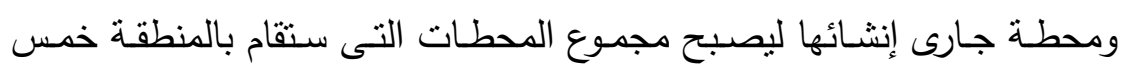
محطات توليد كهربائى. 


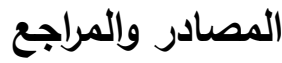

أولاً : المصادر :

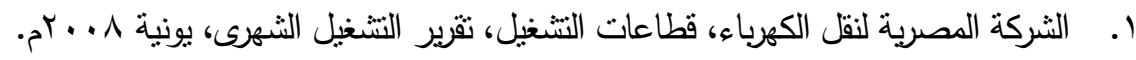

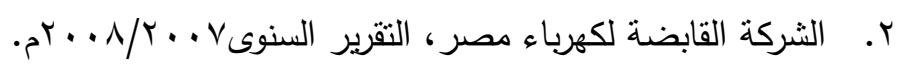

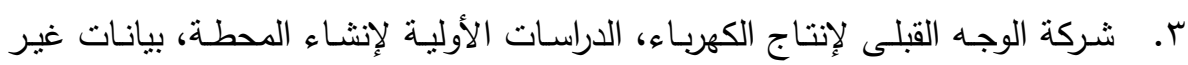

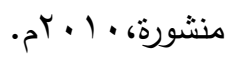

ع. محطـة كهربـاء جنـوب القـاهرة المركبـة (r)، إدارة الثـئون الفنبـة والتدريب والمتابعـة،

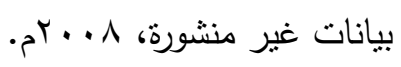

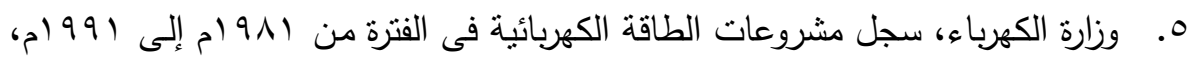

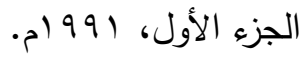

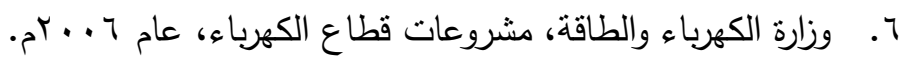

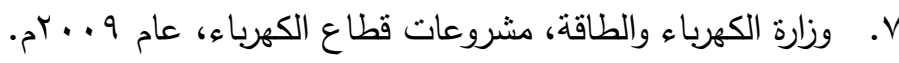

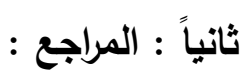

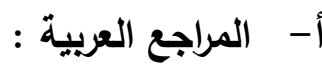

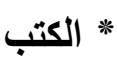

ا. محمد محمـود ابراهيم الديب، الطاقـة في مصـر - دراسـة تحليليـة فيى اقتصـاديات

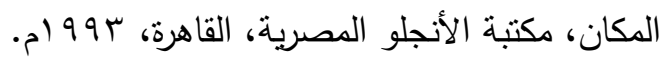

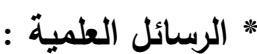

ا. جيهان ابوبكر محمد الصاوى، إنتاج الطاقة الكهربائية واستهلاكها فى محافظة البحيرة

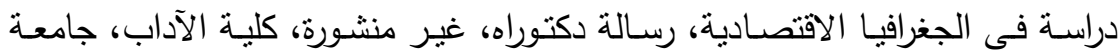

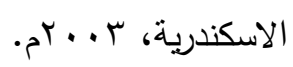

r. زكى أحمد مرشـد محمد، منظومـة الطاقة الكهربائية في اليمن - دراسـة فى جغرافيـة

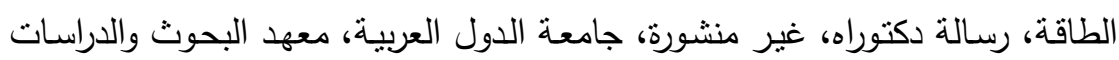

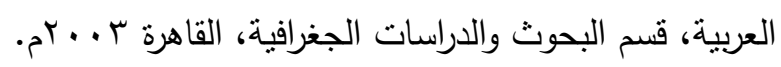

r. سعبد أحمد عبده، جغرافية الطاقة الكهربائية فى مصر - دراسة فى الجغرافيا الاقتصادية،

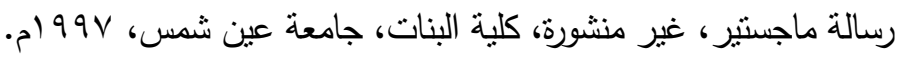


ع. . فاتح شـعبان شعبان، جغرافيـة الطاقـة الكهربائيـة فى سـوريا، رسـالة ماجستير ، غير

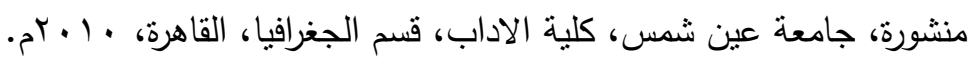

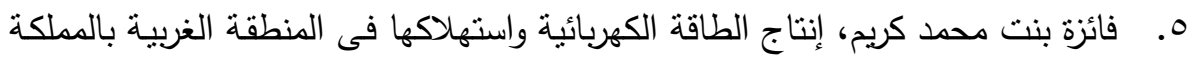
العربية السعودية - دراسة فى الجغرافيا الاقتصادية، الرئاسة العامة لتعليم البنات، كلية

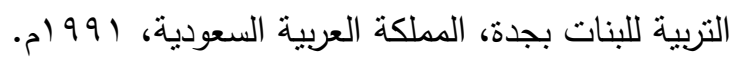

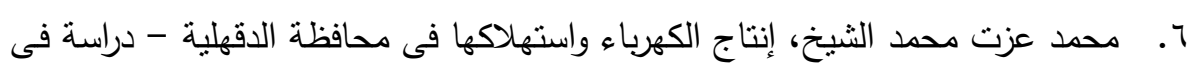

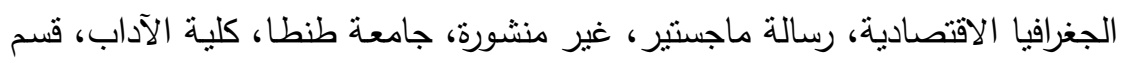

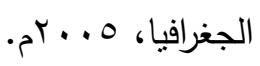

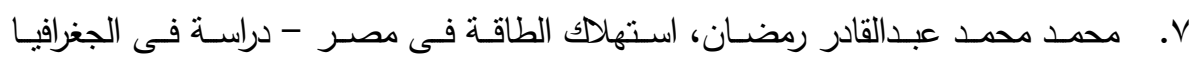

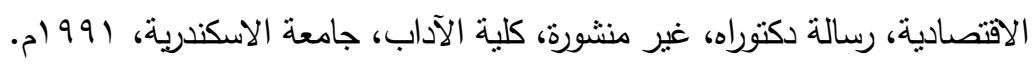

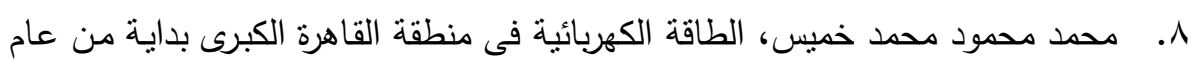

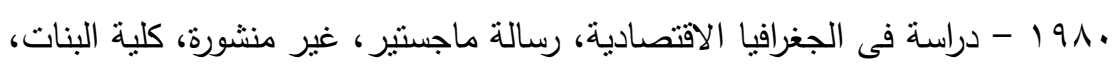

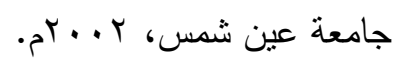

9. ياسرابراهيم محمد الجمال، الطاقة الكهربائية فى محافظة دمياط- دراسة فى الجغرافية الاقتصادية، رسالة دكتوراه، غير منشورة، جامعة المنوفية، كلية الآداب، قسم الجغرافيا،

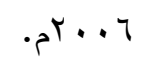

\section{* المجلات والدوريات :}

1. سعبد أحمد عبده، جغرافيـة الطاقة: مفهومها، ومجالها، ومناهجها، المجلة الجغرافيـة

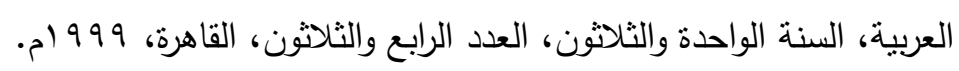

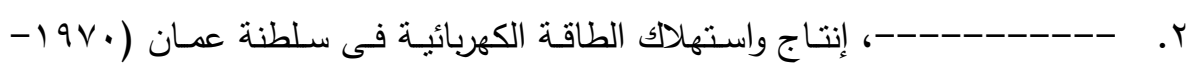

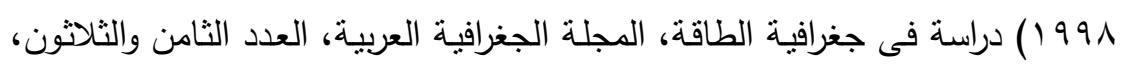

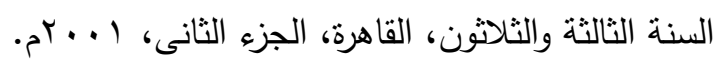

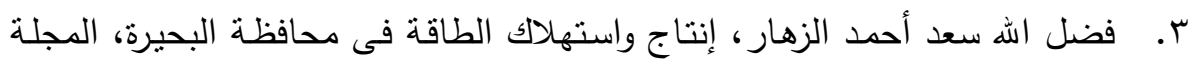

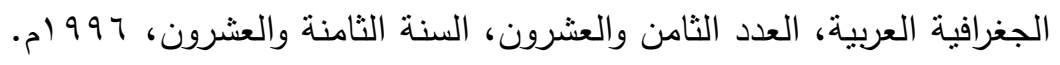

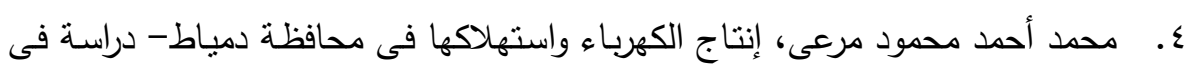

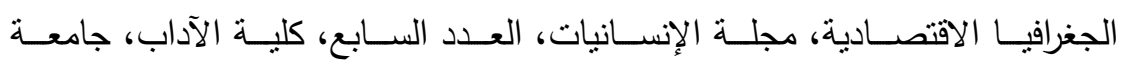
الاسكندرية، ا . . بم. 
ه. محمد محمود إبراهيم الديب، إنتاج واستهلاك الطاقة الكهربائية فى مصر ، مجلة مصر

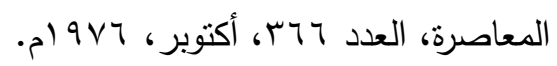

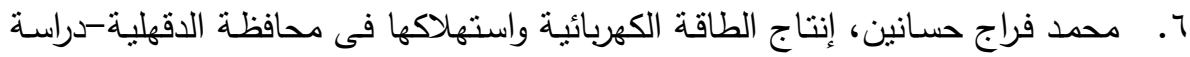

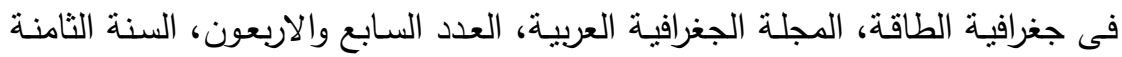
والثلاثون، القاهرة، 7 + . rم.

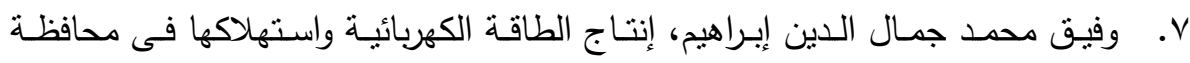

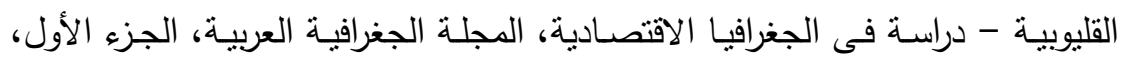

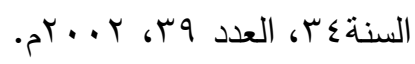

\section{* البحوث والندوات والمؤتمرات :}

1. حمدى كمال هاشم، التلوث البيئى لمحطات توليد الكهرباء الحرارية فى مصر ، دراسة فئة حالة نطبيقية، محطة توليد الكهرباء بالكريمات، ندوة مشكلات البيئة فى مصر ، جامعة لهاء

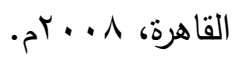

r. سعيد أحمد عبده، الطاقة الكهربائية فى الوطن العربى مع التطبيق على مصر ، الجزء الته

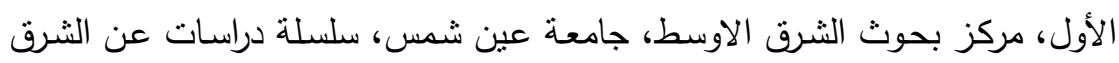

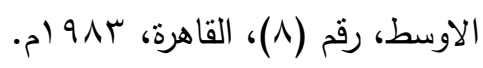

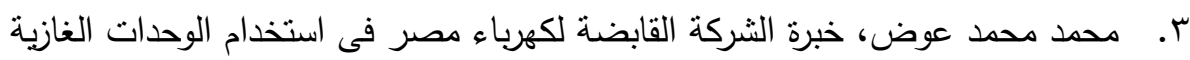

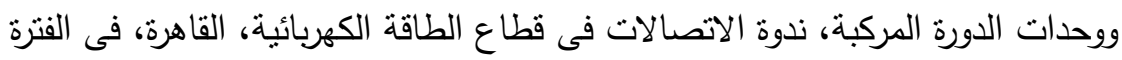

$$
\cdot r \cdot T / 11 / 9-1
$$

\section{ب- المراجع الاجنبية :}

1. Chapman, J.D., "Geography and Energy Commercial Energy Systems and National Policies", United States, New York, 1989.

2. Jefferson, W. Tester \& Others, "Energy and the Environment in the $21^{\text {st }}$ Century" MIT Press, London, 1991.

3. Proceeding of The Expert Group Meeting on The Privatization of Electric Power Sector, Beirut, 1-4 November, 1999. United Nations, 1999.

4. Schaffer, J. \& Others, "Clean Energy Solutions", United States, July 2006.

$$
\text { * * * }
$$

